US Army Corps

of Engineers $s_{\circledast}$

Engineer Research and

Development Center

\title{
Determination of Structural Properties of Airfield Matting
}

Lyan Garcia and Nolan R. Hoffman

March 2019 
The U.S. Army Engineer Research and Development Center (ERDC) solves the nation's toughest engineering and environmental challenges. ERDC develops innovative solutions in civil and military engineering, geospatial sciences, water resources, and environmental sciences for the Army, the Department of Defense, civilian agencies, and our nation's public good. Find out more at www.erdc.usace.army.mil.

To search for other technical reports published by ERDC, visit the ERDC online library at http://acwc.sdp.sirsi.net/client/default. 


\section{Determination of Structural Properties of Airfield Matting}

Lyan Garcia and Nolan R. Hoffman

Geotechnical and Structures Laboratory

U.S. Army Engineer Research and Development Center

3909 Halls Ferry Road

Vicksburg, MS 39180-6199

Final report

Approved for public release; distribution is unlimited.

Prepared for Headquarters, Air Force Civil Engineer Center

Tyndall Air Force Base, FL 32403-5319

Under Project Number 471376 


\section{Abstract}

The evaluation of the interaction between airfield matting and soil under aircraft loading has been part of ongoing investigations under the AMX and Remote Piloted Aircraft (RPA) lightweight mat programs. Full-scale evaluations on controlled subgrades using simulated aircraft loads have successfully provided a realistic performance measure of airfield mats in an operational environment. To better understand airfield mat behavior, a medium-scale bending experiment was performed to determine structural properties that can be related to field performance. This report presents data from experiments performed on new, lightweight matting systems investigated under the AMX and RPA lightweight mat programs using the medium-scale simply supported bending test. Full-scale traffic testing has previously been completed, but the structural and mechanical properties of the lightweight airfield mat designs have not been determined. A finite element implementation of the Mindlin plate theory was used to backcalculate mat modulus and flexural stiffness. Results showed reasonable relationships with field performance.

DISCLAIMER: The contents of this report are not to be used for advertising, publication, or promotional purposes. Citation of trade names does not constitute an official endorsement or approval of the use of such commercial products. All product names and trademarks cited are the property of their respective owners. The findings of this report are not to be construed as an official Department of the Army position unless so designated by other authorized documents. 


\section{Contents}

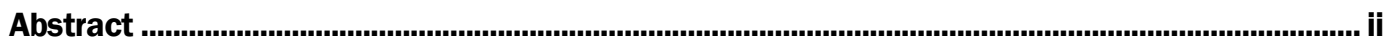

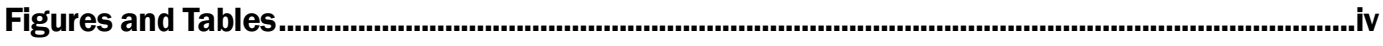

Preface ......................................................................................................................................

Unit Conversion Factors ........................................................................................................................vii

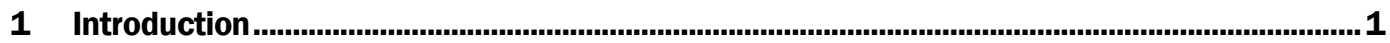

1.1 Lightweight airfield matting programs .............................................................. 1

1.2 Airfield mat characterization...................................................................... 2

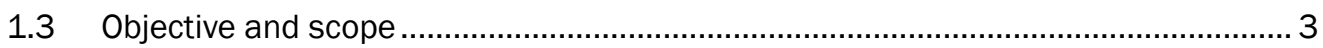

1.4 Organization of report .......................................................................................... 3

2 Description of Matting Systems .......................................................................................... 4

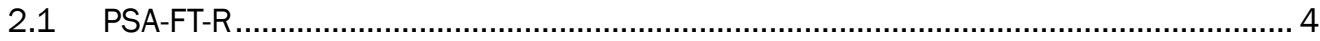

2.2 Aluminum Logistics Military Airfield Take-off and Landing Surface

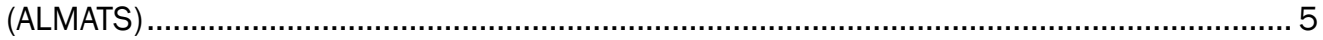

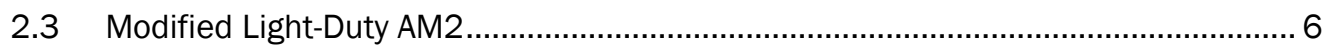

$2.4 \quad$ S46

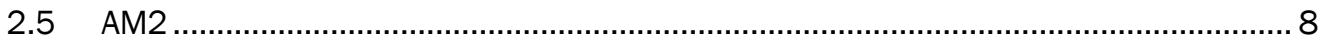

3 Experimental Program .........................................................................................................10

3.1 Description of test ............................................................................................... 10

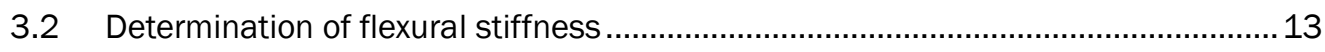

4 Results and Analysis ............................................................................................................15

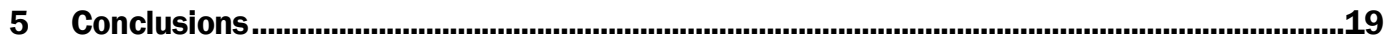

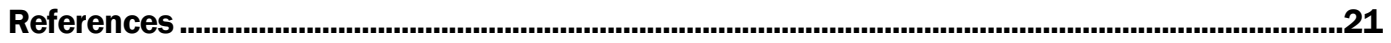

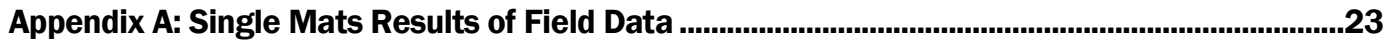

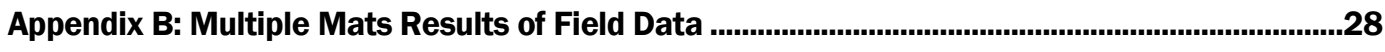

Appendix C: Rectangular Plate Model Solution for Single Panel Configuration Tests................36

Appendix D: Rectangular Plate Model Solution for Multiple Panel Configuration Tests.............42

Report Documentation Page 


\section{Figures and Tables}

\section{Figures}

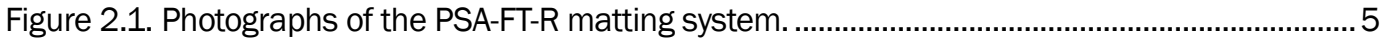

Figure 2.2. Photographs of ALMATS matting system. ....................................................................... 6

Figure 2.3. Modified light-duty AM2 connected mats test setup. ……………………………….....

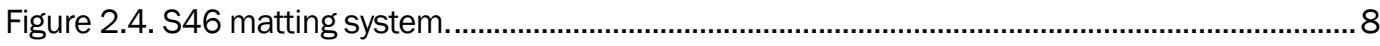

Figure 2.5. AM2 airfield mat stack . ..............................................................................................

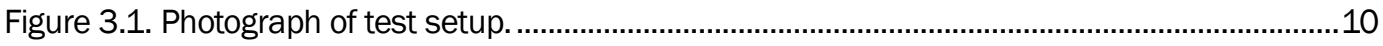

Figure 3.2. AM2 single panel test. ............................................................................................12

Figure 3.3. Multiple panel configuration test ............................................................................13

Figure 3.4. Input data of AM2 mat, single panel test......................................................................14

Figure 3.5. Back-calculated flexural rigidity of AM2 mat, single panel test. ......................................14

Figure 4.1. AM2 single panel test recorded deflection data (72-in. span)........................................15

Figure 4.2. AM2 single panel test, deflection vs load plot (72-in. span). ..........................................16

Figure A.1. AM2 single panel test recorded deflection (120-in. span). ............................................23

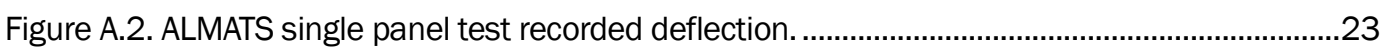

Figure A.3. PSA-FT-R single panel test recorded deflection...............................................................24

Figure A.4. Modified Light-Duty AM2 single panel test recorded deflection......................................24

Figure A.5. S46 single panel test recorded deflection. ....................................................................25

Figure A.6. AM2 single panel test, deflection vs load (120-in. span)...............................................25

Figure A.7. ALMATS single panel test, deflection vs. load. ...............................................................26

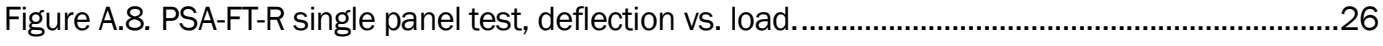

Figure A.9. Modified Light-Duty AM2 single panel test, deflection vs. load. ......................................2

Figure A.10. S46 single panel test, deflection vs. load. .......................................................................2

Figure B.1. AM2 multiple panel test, recorded deflection (72-in. span).............................................28

Figure B.2. AM2 multiple panel test, recorded deflection (120-in. span) ..........................................29

Figure B.3. ALMATS multiple panel test, recorded deflection.............................................................29

Figure B.4. PSA-FT-R multiple panel test, recorded deflection (3 panels)...........................................30

Figure B.5. PSA-FT-R multiple panel test, recorded deflection ( 6 panels)...........................................30

Figure B.6. Modified Light-Duty AM2 multiple panel test, recorded deflection...................................31

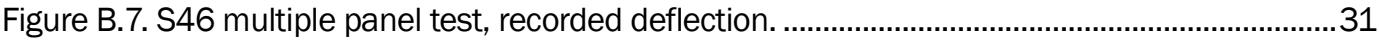

Figure B.8. AM2 multiple panel test, deflection vs. load (72-in. span) ..............................................32

Figure B.9. AM2 multiple panel test, deflection vs. load (120-in. span) ...........................................32

Figure B.10. ALMATS multiple panel test, deflection vs. load.........................................................33

Figure B.11. Modified Light-Duty AM2 multiple panel test, deflection vs. load....................................33

Figure B.12. S46 multiple panel test, deflection vs. load..............................................................34

Figure B.13. PSA-FT-R multiple panel test, deflection vs. load (3 panels)..........................................34

Figure B.14. PSA-FT-R multiple panel test, deflection vs. load (6 panels) .........................................35 
Figure C.1. Input data for AM2 single panel test (120-in. span)......................................................36

Figure C.2. Output data for AM2 single panel test (120-in. span).....................................................37

Figure C.3. Input data for PSA-FT-R single panel test.....................................................................37

Figure C.4. Output data for PSA-FT-R single panel test.................................................................38

Figure C.5. Input data for ALMATS single panel test. ………........................................................38

Figure C.6. Output data for ALMATS single panel test. ……………................................................39

Figure C.7. Input data for Modified Light-Duty AM2 single panel test...............................................39

Figure C.8. Output data for Modified Light-Duty AM2 single panel test. ............................................40

Figure C.9. Input data for S46 single panel test. .......................................................................40

Figure C.10. Output data for S46 single panel test. ......................................................................... 41

Figure D.1. Input data for AM2 multiple panel test (72-in. span). ....................................................42

Figure D.2. Output data for AM2 multiple panel test (72-in. span)....................................................43

Figure D.3. Input data for AM2 multiple panel test (120-in. span). ...................................................43

Figure D.4. Output data for AM2 multiple panel test (120-in. span). ...............................................44

Figure D.5. Input data for PSA-FT-R multiple panel test (3 panels)...................................................44

Figure D.6. Output data for PSA-FT-R multiple panel test (3 panels)................................................45

Figure D.7. Input data for PSA-FT-R multiple panel test (6 panels). ..................................................45

Figure D.8. Output data for PSA-FT-R multiple panel test (6 panels).................................................46

Figure D.9. Input data for ALMATS multiple panel test. ..................................................................46

Figure D.10. Output data for ALMATS multiple panel test. .................................................................4

Figure D.11. Input data for Modified Light-Duty AM2 multiple panel test.........................................4

Figure D.12. Output data for Modified Light Duty AM2 multiple panel test.......................................48

Figure D.13. Input data for S46 multiple panel test.....................................................................48

Figure D.14. Output data for S46 multiple panel test. .....................................................................49

\section{Tables}

Table 2.1. Physical properties of matting systems. ..................................................................... 4

Table 3.1. Single and multiple panel test configuration. .................................................................12

Table 4.1. Back-calculated flexural rigidity for the mats tested. ........................................................17 


\section{Preface}

This study was conducted for the U.S. Air Force Civil Engineer Center (AFCEC). Technical oversight was provided by Mr. Jeb S. Tingle.

The work was performed by the Airfields and Pavements Branch (GMA) of the Engineering Systems and Materials Division (GM), U.S. Army Engineer Research and Development Center, Geotechnical and Structures Laboratory (ERDC-GSL). At the time of publication, Dr. Timothy W. Rushing was Chief, CEERD-GMA; Mr. Jeffrey G. Averett was Acting Chief, CEERD-GM; and Mr. R. Nicholas Boone, CEERD-GVT, was the Technical Director for Force Projection and Maneuver Support. The Deputy Director of ERDC-GSL was Mr. Charles W. Ertle II, and the Director was Mr. Bartley P. Durst.

COL Ivan P. Beckman was the Commander of ERDC, and Dr. David Pittman was the Director. 


\section{Unit Conversion Factors}

\begin{tabular}{|c|c|c|}
\hline Multiply & By & To Obtain \\
\hline cubic feet $\left(\mathrm{ft}^{3}\right)$ & 0.02831685 & cubic meters \\
\hline cubic inches (in. ${ }^{3}$ ) & $1.6387064 \mathrm{E}-05$ & cubic meters \\
\hline feet $(\mathrm{ft})$ & 0.3048 & meters \\
\hline foot-pounds force (ft-lb) & 1.355818 & joules \\
\hline inches (in.) & 0.0254 & meters \\
\hline inch-pounds (force) & 0.1129848 & newton meters \\
\hline kip-inches & 112.948 & newton-meters \\
\hline pounds (force) (Ib) & 4.448222 & newtons \\
\hline pounds (force) per foot (lb/ft) & 14.59390 & newtons per meter \\
\hline pounds (force) per inch (lb/in.) & 175.1268 & newtons per meter \\
\hline pounds (force) per square foot $\left(\mathrm{lb} / \mathrm{ft}^{2}\right)$ & 47.88026 & pascals \\
\hline pounds (force) per square inch (lb/in. ${ }^{2}$ ) & 6.894757 & kilopascals \\
\hline pounds (mass) (lb) & 0.45359237 & kilograms \\
\hline pounds (mass) per cubic foot $\left(\mathrm{lb} / \mathrm{ft}^{3}\right)$ & 16.01846 & kilograms per cubic meter \\
\hline pounds (mass) per cubic inch (lb/in. ${ }^{3}$ ) & $2.757990 \mathrm{E}+04$ & kilograms per cubic meter \\
\hline pounds (mass) per square foot $\left(\mathrm{lb} / \mathrm{ft}^{2}\right)$ & 4.882428 & kilograms per square meter \\
\hline square feet $\left(\mathrm{ft}^{2}\right)$ & 0.09290304 & square meters \\
\hline square inches (in. ${ }^{2}$ ) & $6.4516 \mathrm{E}-04$ & square meters \\
\hline tons (force) & $8,896.443$ & newtons \\
\hline tons (force) per square foot (tons/ft²) & 95.76052 & kilopascals \\
\hline tons (long) per cubic yard (tons/yd $\mathrm{y}^{3}$ ) & $1,328.939$ & kilograms per cubic meter \\
\hline tons (nuclear equivalent of TNT) & 4.184 E+09 & joules \\
\hline tons $(2,000$ pounds, mass $)$ & 907.1847 & kilograms \\
\hline tons $\left(2,000\right.$ pounds, mass) per square foot (tons $\left./ \mathrm{ft}^{2}\right)$ & $9,764.856$ & kilograms per square meter \\
\hline
\end{tabular}




\section{Introduction}

\subsection{Lightweight airfield matting programs}

Expedient surfacing systems have been used since the 1940s to rapidly construct and expand existing airfield facilities during contingency operations. The primary expeditionary airfield surfacing for the U.S. military is AM2 airfield mat, which has been in service as a temporary runway, taxiway, and parking apron surface since the 1960s. Although AM2 has a long history of satisfactory performance, its weight and dimensions are limiting factors in its deployability. Typically, aircraft payload limits are exceeded without approaching cubage limits, and an excessive number of aircraft are required to deliver AM2 to contingency locations.

To address AM2's logistical challenges, the AMX program was initiated by the U.S. Air Force (USAF) to develop a lightweight replacement for AM2 matting. The joint services agreed upon an objective thickness of 1.25 in., an objective maximum unit weight of $3.8 \mathrm{lbf} / \mathrm{ft}^{2}$, and required that the mats fit on a 463L pallet, which has useable dimensions of 104 in. by 84 in. In addition, the mat system was required to sustain 1,500 passes of F${ }_{15} \mathrm{E}$ traffic over a subgrade with a California Bearing Ratio (CBR) of 6 . The pass requirement was determined by baseline testing of AM2 (Rushing and Tingle 2007). For over a decade, commercial matting systems have been investigated as part of the AMX program (Rushing et al. 2009; Garcia et al. 2012; Rushing et al. 2012). Details for the most recent testing performed at the Engineer Research and Development Center (ERDC) under this program can be found in Garcia and Hoffman (2018).

The U.S. military began using remote piloted aircraft (RPAs) for reconnaissance and offensive operations in the mid 1990s. Their effectiveness has led to the development of several new models with increasing capability and operational requirements, and they are now a major part of air operations. The majority of models are relatively small in comparison to manned fighter and cargo aircraft. Because of their smaller size and weight, expedient surfaces needed to support expeditionary operations do not have to be as robust as systems designed to support manned aircraft, such as the AM2 matting system. RPAs are also more sensitive to roughness on the mat surface, and AM2 is unsuitable for some unmanned aircraft. However, only AM2 is available through standard 
procurement methods as an approved aircraft operating surface. To improve operational effectiveness, a light-duty expeditionary mat system is desired that can effectively support RPA operations while reducing the logistical footprint. A full-scale evaluation was conducted on four commercial matting systems at ERDC. Details are provided in Garcia et al. (2017). Based on these evaluations, ERDC researchers were able to recommend lightweight mat designs to customers for expansion of airfields to support RPAs.

\subsection{Airfield mat characterization}

To evaluate the performance of matting systems, the most common approach has been to build a full-scale test section with a controlled subgrade overlaid by a matting surface that is trafficked to failure by using simulated loads. Although this has provided a realistic performance measure, full-scale testing of matting systems is costly. Several researchers have attempted to identify a mechanism for using laboratory characterization of matting and relating this information to full-scale field performance under dynamic loading. The following paragraphs summarize recent characterization research.

Gonzalez and Rushing (2010) used a stress-based approach to develop a mechanistic model for the purpose of predicting passes-to-failure of a mat system based on subgrade strength in terms of CBR. They used a simple bending test setup described by Berney et al. (2006) and a finite element implementation of the Mindlin plate solution (Mindlin 1951) for determining the unit section modulus of different mat systems. The unit section modulus is the overall material resistance to bending. The test method of Berney et al. (2006) is described in detail in Chapter 3 of this report.

Garcia and Howard (2016) developed a simplified expression to predict subgrade deformation on a CBR of 6 as a function of F-15E aircraft passes and airfield mat properties. The unit section modulus determined through the Mindlin plate solution was required for input in the simplified model.

As described above, new matting systems that have not been fully characterized have been tested under the AMX and RPA programs. Therefore, researchers at ERDC performed medium-scale laboratory testing using the simply supported beam setup to experimentally 
determine the unit section modulus and flexural stiffness of matting systems described by Garcia and Hoffman (2018) and Garcia et al. (2017).

\subsection{Objective and scope}

The research presented in this report describes the medium-scale simply supported bending tests and the use of the resulting data to calculate mat performance parameters. Although full-scale performance testing under simulated aircraft traffic has been completed, the structural and mechanical properties of the lightweight airfield mat designs have not been determined. The tests were performed to determine the structural properties by using a finite element implementation of the Mindlin plate theory. Results obtained for the lightweight matting systems were compared to the AM2 airfield mat system properties.

\subsection{Organization of report}

The body of this report is organized into five chapters. The first chapter is the introduction, and Chapter 5 is the conclusion. Chapter 2 describes the matting systems, and Chapter 3 details the experimental program. The data and analysis are described in detail in Chapter 4. 


\section{Description of Matting Systems}

Physical properties of the five airfield mat systems included in this experiment are described in this section. The PSA-FT-R and the ALMATS mat systems were evaluated in full-scale test sections as part of the RPA program. The S46 mat system was evaluated as part of the AMX program. The Modified Light-Duty AM2 was tested under the loading conditions of both programs. AM2 was included in this experiment for comparison to the lightweight mats. Dimensions and weight of a full panel of each mat system are shown in Table 2.1.

Table 2.1. Physical properties of matting systems.

\begin{tabular}{|l|l|l|l|l|l|}
\hline & PSA-FT-R & ALMATS & $\begin{array}{l}\text { Modified Light- } \\
\text { Duty AM2 }\end{array}$ & S46 & AM2 \\
\hline Length (in.) & 103.8 & 103.4 & 102 & 83.5 & 144 \\
\hline Width (in.) & 10.4 & 20.0 & 21 & 41.75 & 24 \\
\hline Thickness (in.) & 0.88 & 1.0 & 1.5 & 1.17 & 1.5 \\
\hline Weight (Ib) & 26.10 & 57.1 & 57.17 & 103.9 & 144 \\
\hline Unit Surface Weight (psf) & 3.49 & 3.97 & 4.00 & 4.29 & 6.1 \\
\hline Material & AA 6082 & AL 6082 & AA 6061 & AA 6005A & AA 6061 \\
\hline Manufacturer & $\begin{array}{l}\text { FAUN } \\
\text { Trackway }\end{array}$ & Alfab, Inc. & Taber/HFW & $\begin{array}{l}\text { FAUN } \\
\text { Trackway }\end{array}$ & Alfab, Inc. \\
\hline
\end{tabular}

*All dimensions and weight are for full panels

\subsection{PSA-FT-R}

The PSA-FT-R matting system, a modified version of the PSA-FT mat system, was developed by FAUN Trackway to create temporary RPA runways, taxiways, and parking areas. The PSA-FT-R system includes reinforcement at the end connector to improve support at the longitudinal joints where most mat-system failures occur. Each PSA-FT-R panel consisted of a single aluminum extrusion that had a connector welded on each short end to create a single panel. The connectors were made to fit a double-arrow locking key that could be inserted once panels were placed next to each other on the ground. The connection along the long edge was a hinge-type male/female system. The system included both full-size and half-size panels to allow a standard brickwork pattern assembly. Photographs of the matting system are provided in Figure 2.1. Additional details are provided by Garcia et al. (2017). Based on the results of the fullscale test, the PSA-FT-R system was capable of sustaining RPA traffic. 
Figure 2.1. Photographs of the PSA-FT-R matting system.

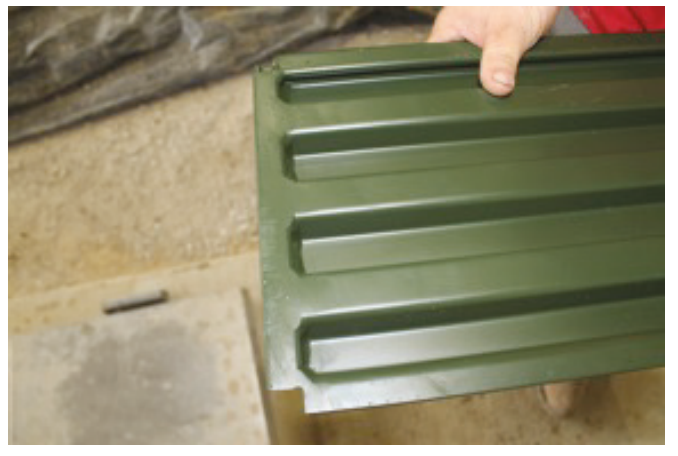

(a) Bottom surface of panels

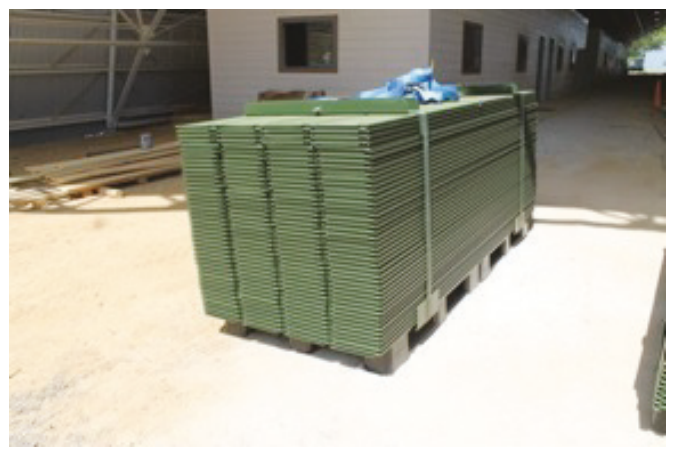

(c) Stack of panels as delivered

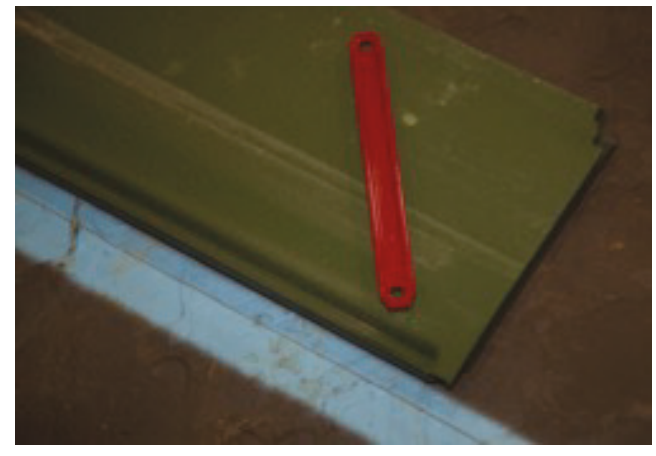

(b) Locking key

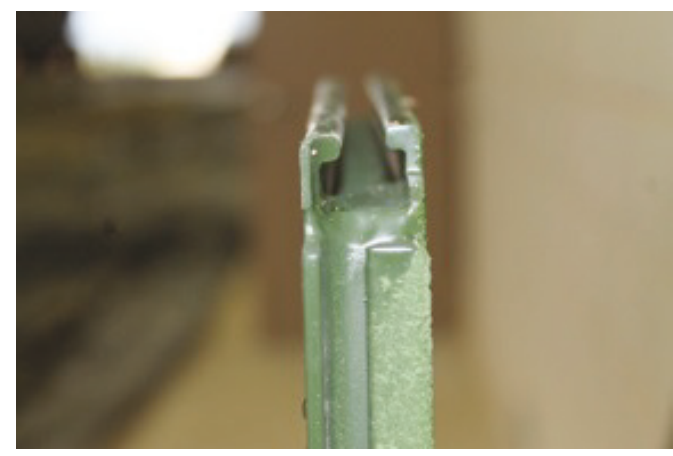

(d) End connector

\subsection{Aluminum Logistics Military Airfield Take-off and Landing Surface (ALMATS)}

The ALMATS matting system was developed by Alfab Inc., the manufacturer of AM2. ALMATS was designed to resemble AM2 at the mechanical joints and core, but to have a reduced panel thickness and length. Each panel consisted of a single, extruded aluminum alloy 6082-T6 core with vertical supports that spanned the length of the panels and were spaced approximately 3 in. apart. Overlap and underlap end connectors were welded onto the short ends of the mat by using a metal insert gas (MIG) welding process to create a single panel. A locking bar was specifically designed to fit the reduced joint cross section of the ALMATS system and secure the overlap/underlap connection. Panels were designed to be compatible with the $463 \mathrm{~L}$ pallet and $20-\mathrm{ft}$ ISO flatracks and were coated with nonskid paint. Photographs of the ALMATS matting system are shown in Figure 2.2. Additional details are provided by Garcia et al. (2017). The ALMATS system was deemed capable of supporting RPAs, but did not meet the AMX program requirements for heavier aircraft. 
Figure 2.2. Photographs of ALMATS matting system.

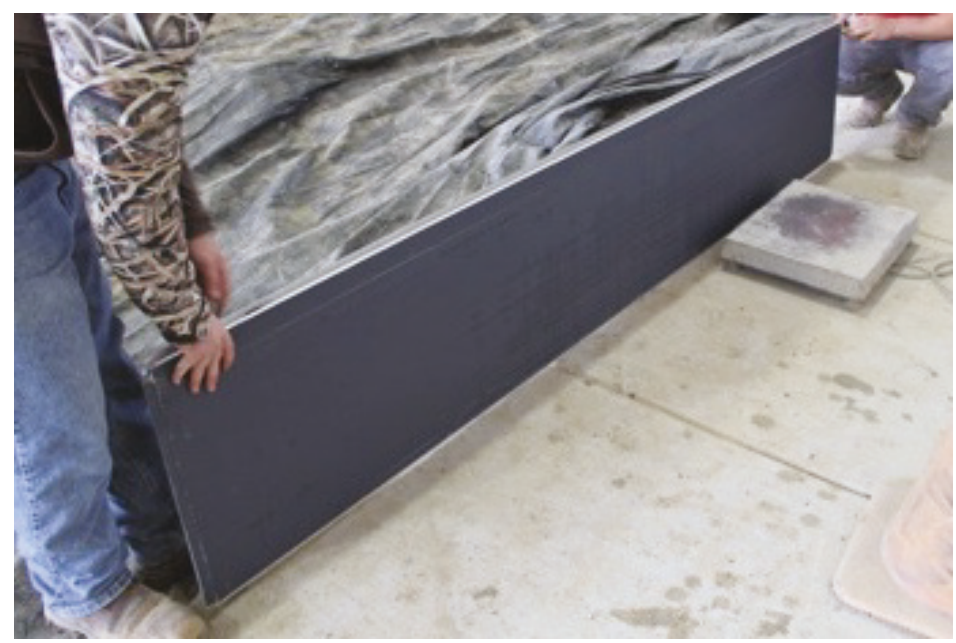

(a) Full panel

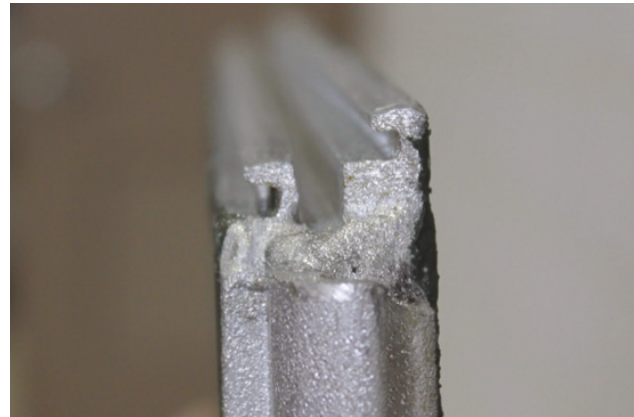

(b) End connector

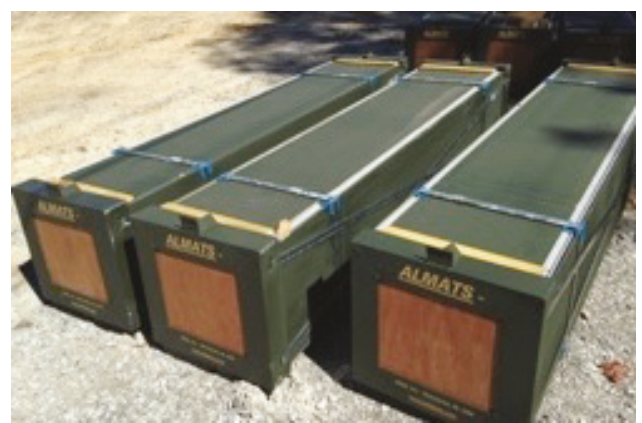

(c) Pallets of panels as delivered

\subsection{Modified Light-Duty AM2}

Modified Light-Duty AM2 panels were originally designed to meet RPA requirements, but were also evaluated for the AMX program because of their excellent performance under RPA loads (Hoffman and Garcia 2018). The matting utilizes the same connection system as AM2; therefore, the longitudinal direction connects via overlap/underlap connectors that create a rectangular slot for a locking bar when connected. The transverse direction of the matting connects via male and female hinge connectors. A photograph of the Modified Light-Duty AM2 connected panels setup for the experiment is shown in Figure 2.3. Additional details on the development of the matting system are provided by Hoffman et al. (2018). The Light-Duty Am2 mat was deemed capable of supporting RPAs but failed to meet the AMX requirements for sustaining heavy aircraft. However, it was able to sustain a significant number of heavy aircraft passes before failure. 
Figure 2.3. Modified light-duty AM2 connected mats test setup.

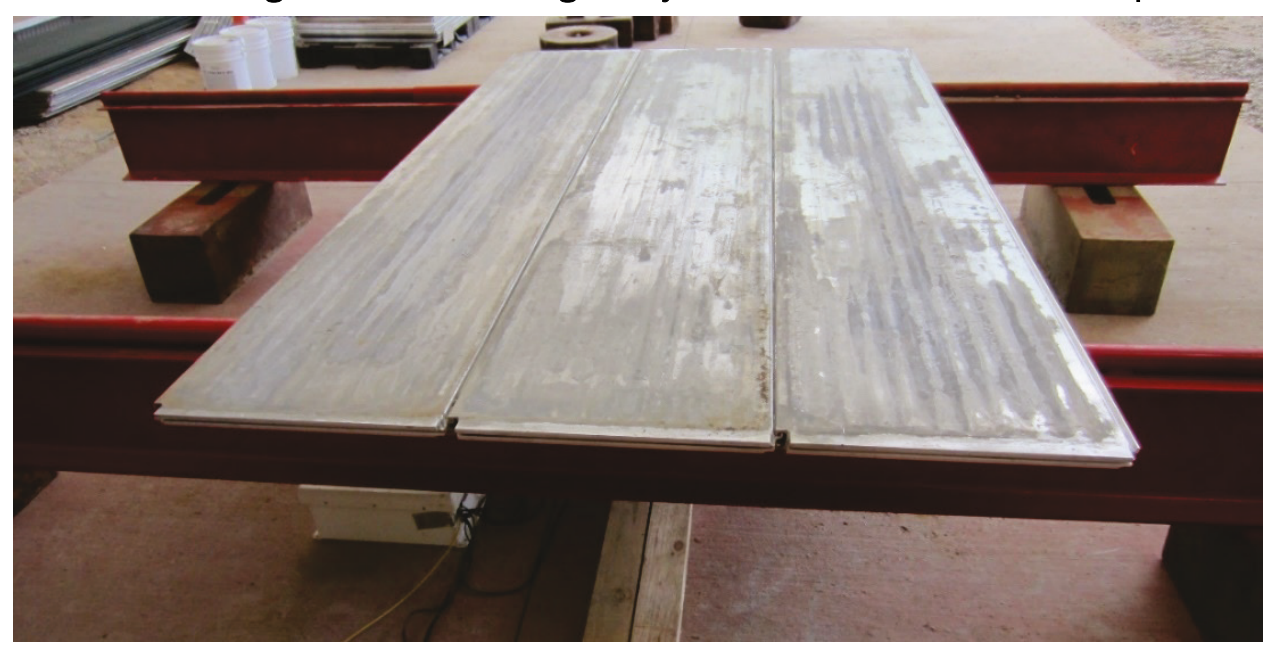

\subsection{6}

The S46 aluminum mat system was developed by Faun Trackway specifically to meet the requirements of the AMX program. The S46 mat system panels consisted of two 6005A T6 aluminum alloy extrusions that were friction stir welded (FSW) to make a single panel core. The core was composed of vertical members that were 0.08 in. thick and spaced at approximately $1.6 \mathrm{in}$. Each extrusion was manufactured such that a vertical member was located on each side of the FSW. End connectors were then MIG welded on the short edge along the length of the connector. The corners were tungsten insert gas (TIG) bonded to the panel matrix. The connection along the four edges of the panels was the same. These were made to fit a double-arrow locking key that could be inserted once panels were placed next to each other on the ground. Half panels were manufactured to allow for a brickwork pattern. The locking key was manufactured with 6082 T6 aluminum alloy. Photographs of the S46 matting system are shown in Figure 2.4. Additional details are provided by Garcia and Hoffman (2018). 
Figure 2.4. S46 matting system.

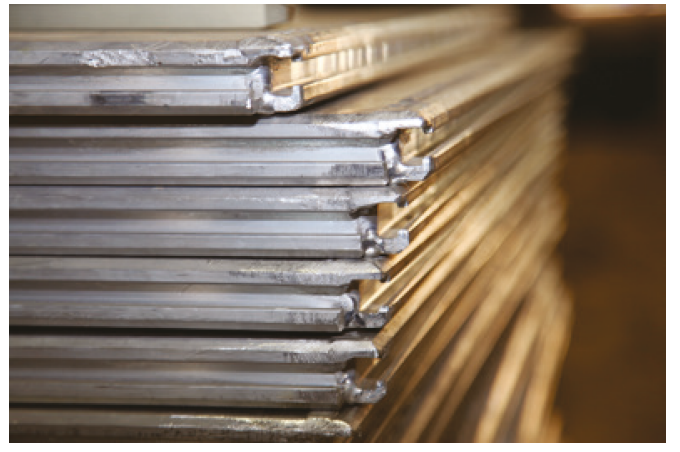

(a) Arrow-shaped connection slot

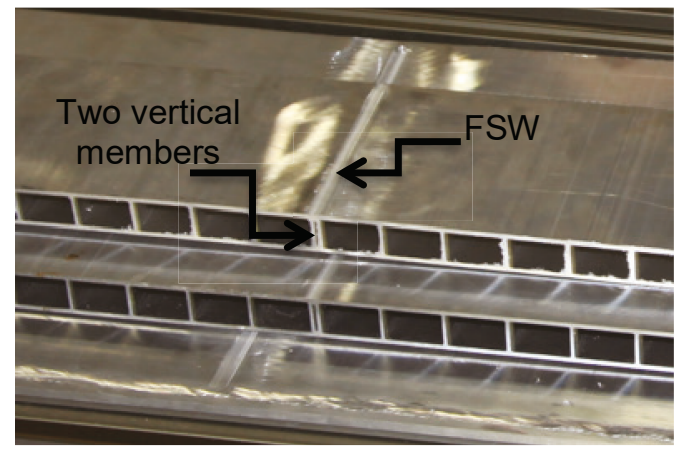

(b) FSW along length of panel

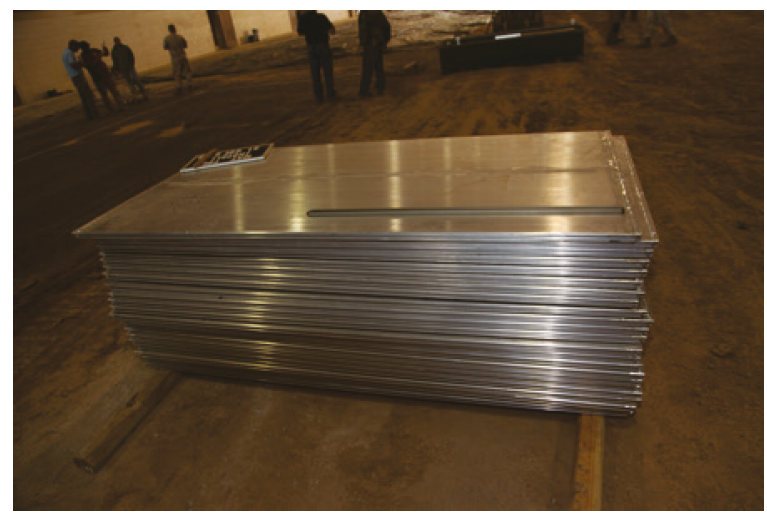

(c) S46 panels

\subsection{AM2}

AM2 airfield mat was developed in the 1960s under a program sponsored by the Naval Air Engineering Center, in Philadelphia, PA. Various versions of AM2 were tested under simulated aircraft loads at the U.S. Army Engineer Waterways Experiment Station in Vicksburg, MS, from 1961 through 1971, with major procurements beginning in 1965. The original AM2 mat has been modified through the years to address limiting structural concerns. The current production version of AM2, MOD 5, is manufactured by Alfab Inc.

Each AM2 panel was fabricated from a single 6061-T6 aluminum alloy extrusion with end connectors welded to the 2-ft ends to form a complete panel. The core of the extruded panels was comprised of vertical stiffeners spaced 1.75 in. apart in the 12-ft direction. The mat was also made in half panels to allow a staggered "brickwork" configuration. The panels were joined along the two 12-ft edges by a hinge-type male/female connection. The adjacent 2-ft ends were joined by an overlap/underlap connection secured by an aluminum locking bar. The panels were coated with an antiskid material to increase the surface friction. A photograph of an AM2 
airfield mat stack is shown in Figure 2.5. Additional details on the matting system are provided in Garcia et al. (2015). AM2 is approved for most heavy aircraft systems.

Figure 2.5. AM2 airfield mat stack.

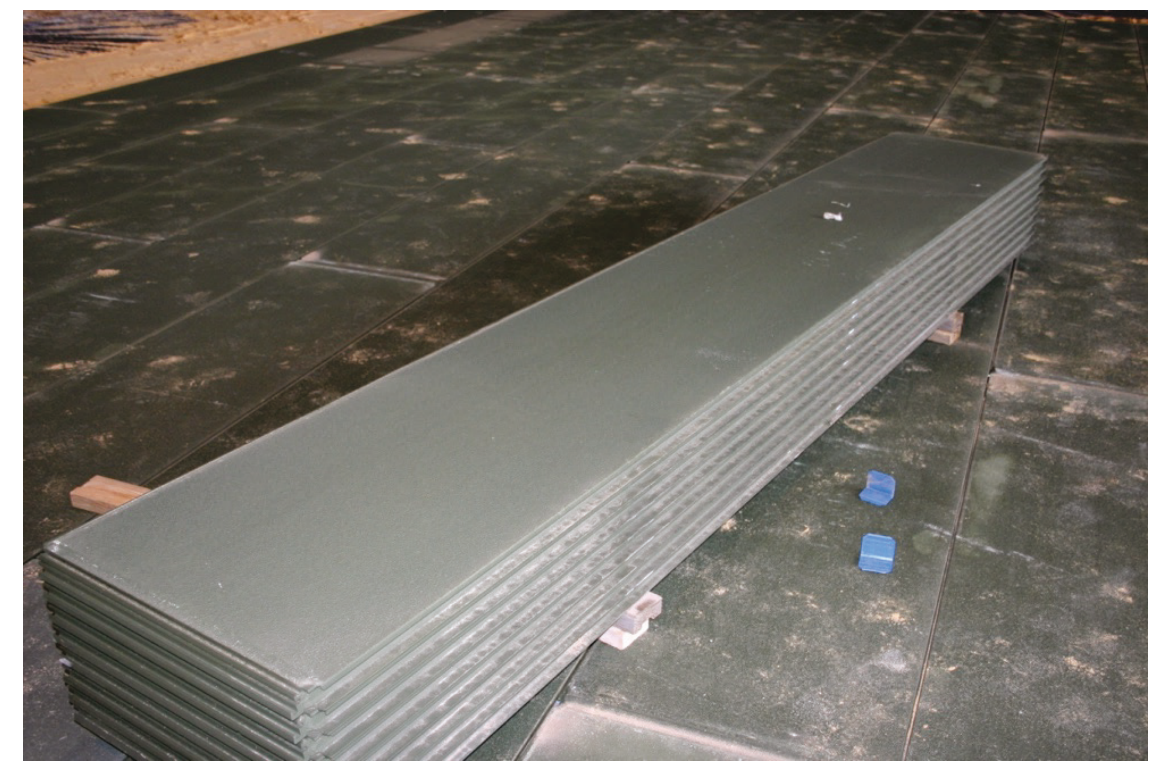




\section{Experimental Program}

This chapter describes the procedures and methods that were used to determine the mechanical properties of the airfield matting systems. The test setup is similar to the ones used in earlier landing mat investigations (Berney et al. 2006; Gonzalez and Rushing 2010). The experiment involved placing a panel on a simply supported beam setup with four deflection gauges placed underneath the mat panel while being incrementally loaded with blocks of known weights. Deflection data were recorded continuously by a computer program for the duration of the test to capture the responses of the mat panels during all loading and unloading cycles. Mats were tested in single and multiple panel configurations to evaluate the influences of the panel transverse joint system. A rectangular plate solution based on the finite element implementation of the Mindlin plate theory was used for determining the unit section modulus.

\subsection{Description of test}

Figure 3.1 shows the setup for a single panel experiment. The test consisted of two parallel supports (beams) on which the panels(s) rested. Blocks were placed under the ends of both supports to provide a stable support system throughout the experiment. The support locations varied according to the panel length, but were placed at least $12 \mathrm{in}$. from the edge of the panel to the support. This was done to avoid slipping of the mats.

Figure 3.1. Photograph of test setup.

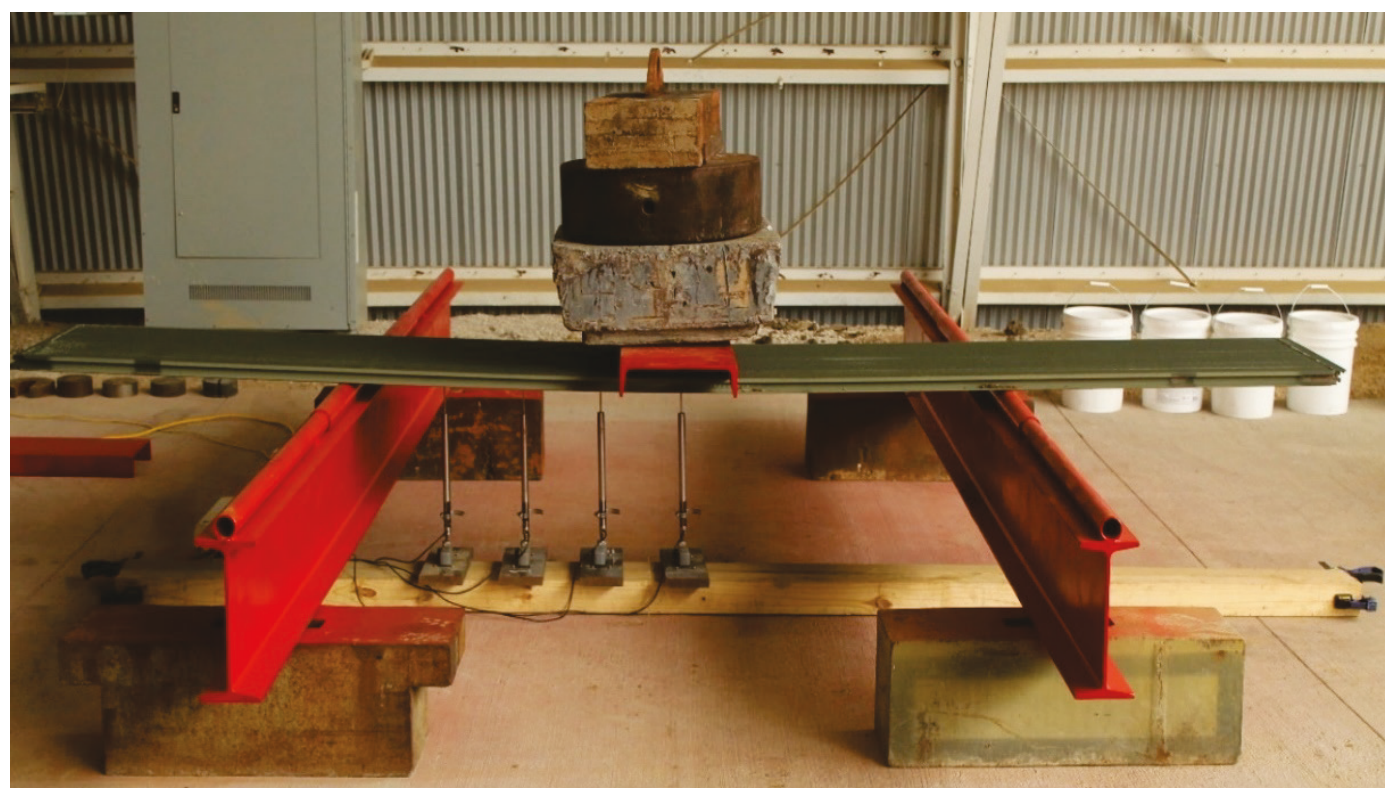


A steel channel beam was placed at the center. The weights used to apply the incremental load were positioned on top of the channel beam to distribute the load evenly across the mat width. Different lengths of channel sections were required depending on the panel size and configuration, but all were 12 in. wide. Channel beam lengths and weights were the following: $9 \mathrm{ft}(187 \mathrm{lb}) 5 \mathrm{ft}(102 \mathrm{lb})$, and $4 \mathrm{ft}(83 \mathrm{lb})$.

Four deflection gauges were placed under the panel. One was placed at the midpoint between supports and the other three were placed at the $1 / 4$ points between the midpoint gauge and one of the supports. For example, if the distance between supports was 72 in., gauges were placed 9 in. apart, starting at the midpoint between supports and proceeding toward one of the supports, as shown in Figure 3.1, where the left support was chosen, to measure the deflection along the centerline of the panel. For multiple panel configurations, the gauges were placed underneath the center panel. Table 3.1 shows details on support distances and gauge locations for each mat system and configuration tested.

Several steel and lead blocks were weighed prior to testing to document their exact weights. These were used to apply load increments of approximately $500 \mathrm{lb} ; 1,000 \mathrm{lb}$; and 2,000 lb. In addition, 5-gal buckets filled with cement (approximately $50 \mathrm{lb}$ each) were also weighed and used to apply smaller load increments.

Deflection gauges were zeroed before placing the steel channel across the panel. A forklift was used throughout the experiment to load the panel(s) with the steel or lead blocks. Deflection data were recorded continuously by a computer program for the duration of the test to capture the response of the mat panels during all loading and unloading cycles. Before any additional load was applied, deflection was allowed to stabilize by leaving the previous applied load in place. Deflection was allowed to reach up to 1.25 in., mostly because of safety concerns that the panels might slip if deflection was allowed to increase further. It was also necessary to measure deflection within the elastic region for simplicity and accuracy in back-calculating the flexural rigidity. Data were also recorded as the panels were unloaded to verify that the gauges returned to their initial reading of $\mathrm{o}$ in., ensuring that the test was performed within the elastic region. An example of a single panel test on AM2 is shown in Figure 3.2. Examples of a multiple panel configuration are shown in Figure 3.3 
Table 3.1. Single and multiple panel test configuration.

\begin{tabular}{|l|l|l|l|}
\hline Matting System & Mat Layout & $\begin{array}{l}\text { Distance } \\
\text { between } \\
\text { Supports (in.) }\end{array}$ & $\begin{array}{l}\text { Gauge Locations, } \\
\text { Measured from } \\
\text { Support (in.) }\end{array}$ \\
\hline PSA-FT-R & 1 mat & 72 & $9,18,27,36$ \\
\hline PSA-FT-R & 3 connected mats & 72 & $9,18,27,36$ \\
\hline PSA-FT-R & 6 connected mats & 72 & $9,18,27,36$ \\
\hline ALMATS & 1 mat & 72 & $9,18,27,36$ \\
\hline ALMATS & 3 connected mats & 72 & $9,18,27,36$ \\
\hline Modified Light-Duty AM2 & 1 mat & 72 & $9,18,27,36$ \\
\hline Modified Light-Duty AM2 & 3 connected mats & 72 & $9,18,27,36$ \\
\hline S46 & 1 mat & 60 & $7.5,15,22.5,30$ \\
\hline S46 & 3 connected mats & 60 & $7.5,15,22.5,30$ \\
\hline AM2 & 1 mat & 72 & $9,18,27,36$ \\
\hline AM2 & 3 connected mats & 72 & $9,18,27,36$ \\
\hline AM2 & 1 mat & 120 in. & $15,30,45,60$ \\
\hline AM2 & 3 connected mats & 120 in. & $15,30,45,60$ \\
\hline
\end{tabular}

Figure 3.2. AM2 single panel test.

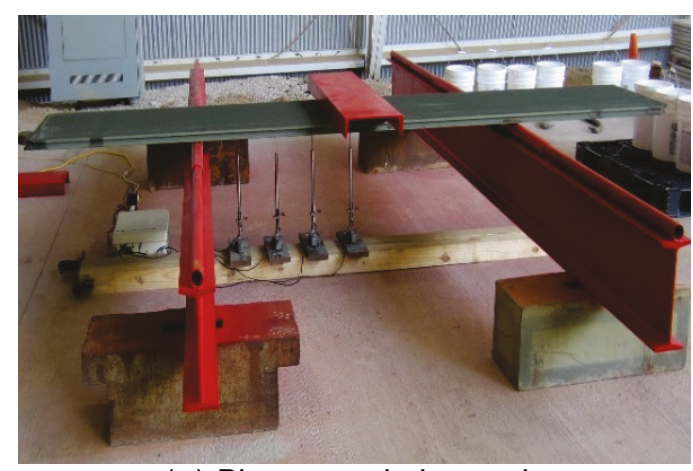

(a) Place steel channel

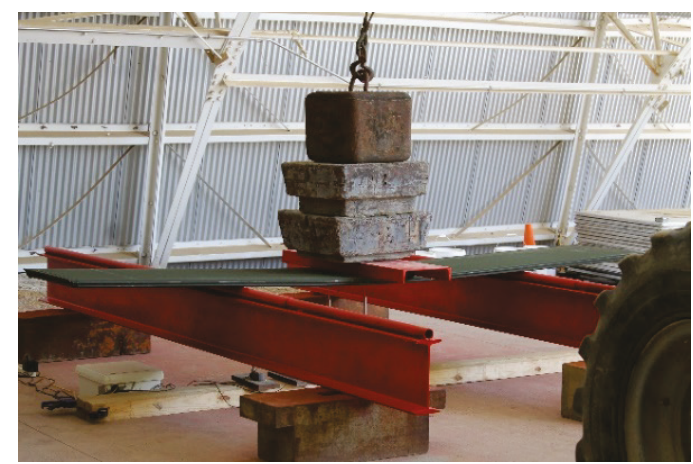

(c) Apply larger load increments

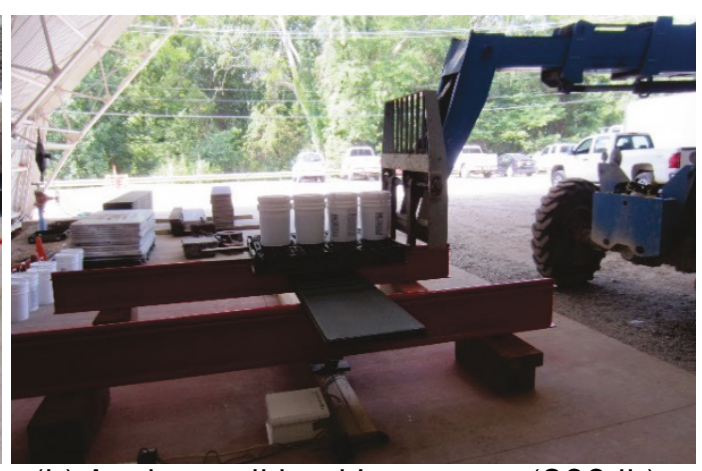

(b) Apply small load increment (200 lb)

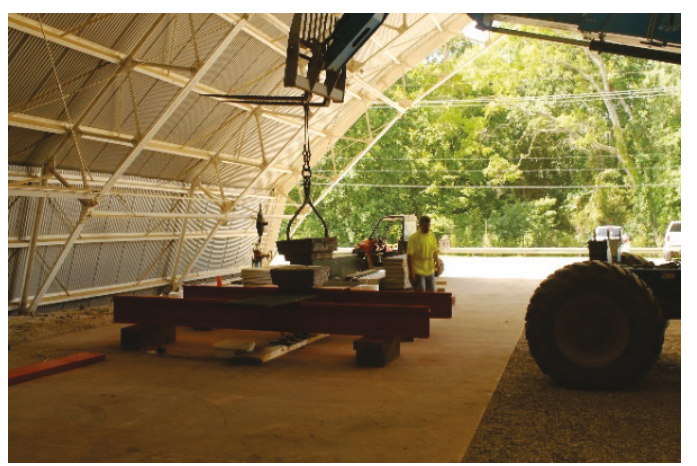

(d) Unload 
Figure 3.3. Multiple panel configuration test

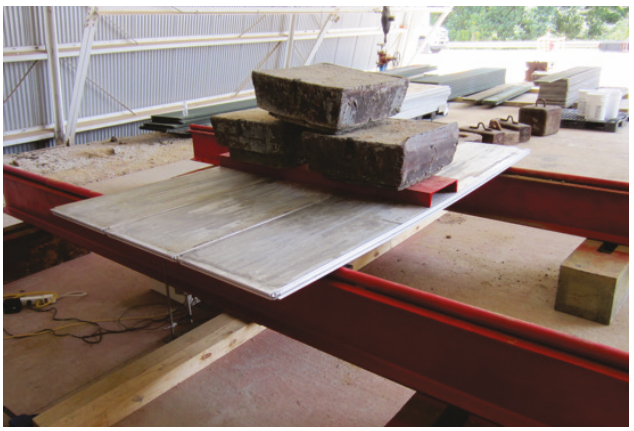

(a) Modified Light-Duty AM2

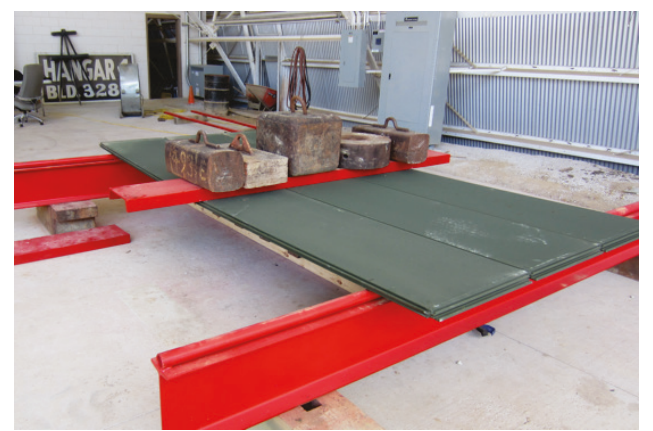

(b) AM2

\subsection{Determination of flexural stiffness}

The deflection data were used to back-calculate the flexural rigidity of each mat by using the rectangular plate solution (Mindlin plate theory; Mindlin 1951). A unit section modulus with a joint (for mats tested in multiple panel configurations) and no joint (for single panel configurations) was determined. Data that included the mat panel dimensions, plate areas in contact with supports (beams), load distribution area, maximum applied load, assumed Poisson's ratio (o.2 for aluminum), and modulus were input in the model. Two loads of equal magnitude were input to represent the two-line loads distributed by the channel (the total load was divided by 2). The modulus of subgrade reaction was input as 1,000 ksi to simulate the fixed parallel beams used for support. An initial modulus of elasticity $(E)$ of the mat was input as 10,000 ksi (modulus of elasticity of aluminum). The modulus of the mat was then varied until the model deflection predicted at the center of the panel was equal to the maximum deflection measured in the field test. A corresponding flexural rigidity $(D)$ was chosen from the results of the model. The flexural rigidity was calculated with Equation 1, where $h$ is the thickness of the mats and $v$ is the Poisson's ratio.

Figure 3.4 shows an example of the input data for a single panel configuration test on AM2. Figure 3.5 shows the output data with the back-calculated flexural stiffness. For additional output and input data for other mats and testing configurations, refer to Appendices C and D.

$$
\mathrm{D}=\mathrm{Eh}^{3} / 12\left(1-\mathrm{v}^{2}\right)
$$


Figure 3.4. Input data of AM2 mat, single panel test.

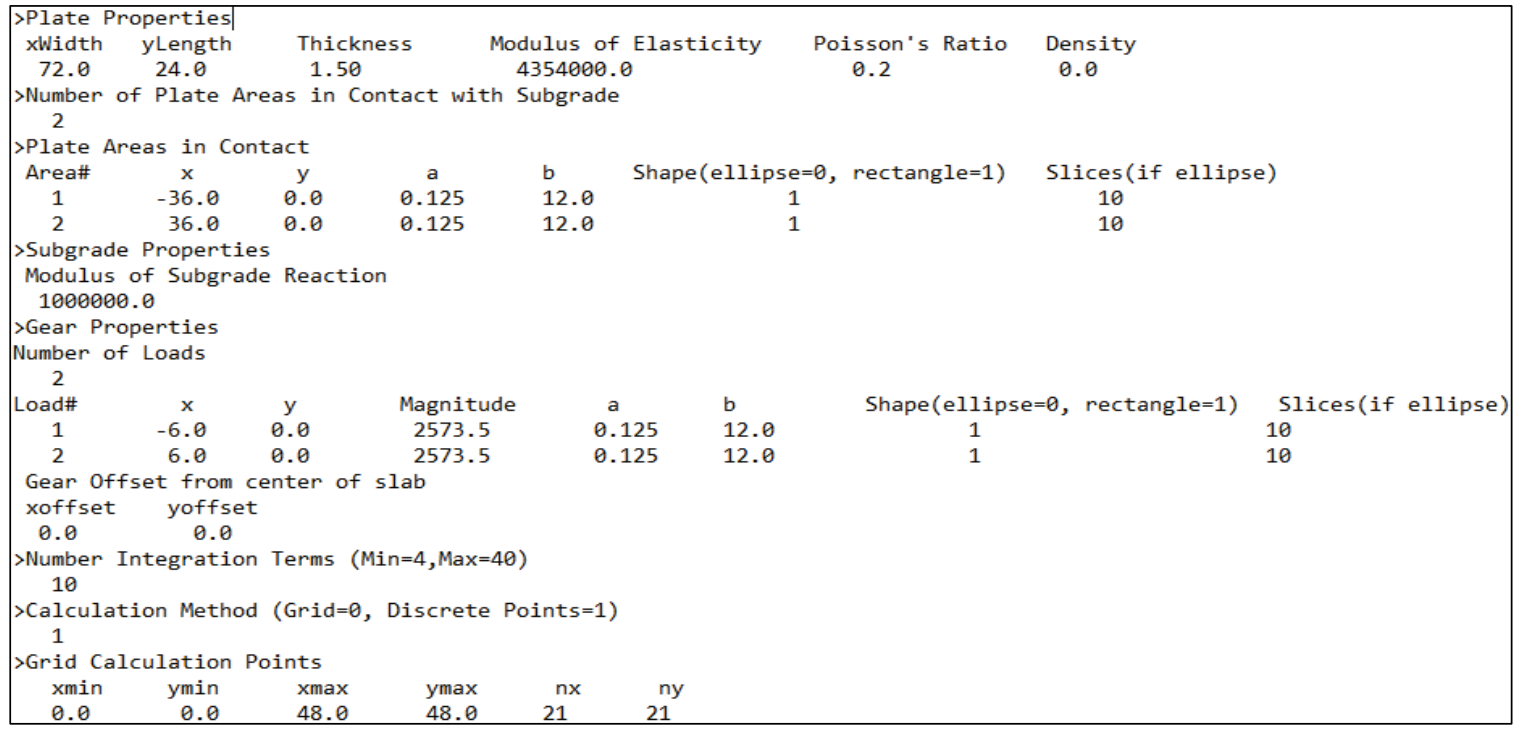

Figure 3.5. Back-calculated flexural rigidity of AM2 mat, single panel test.

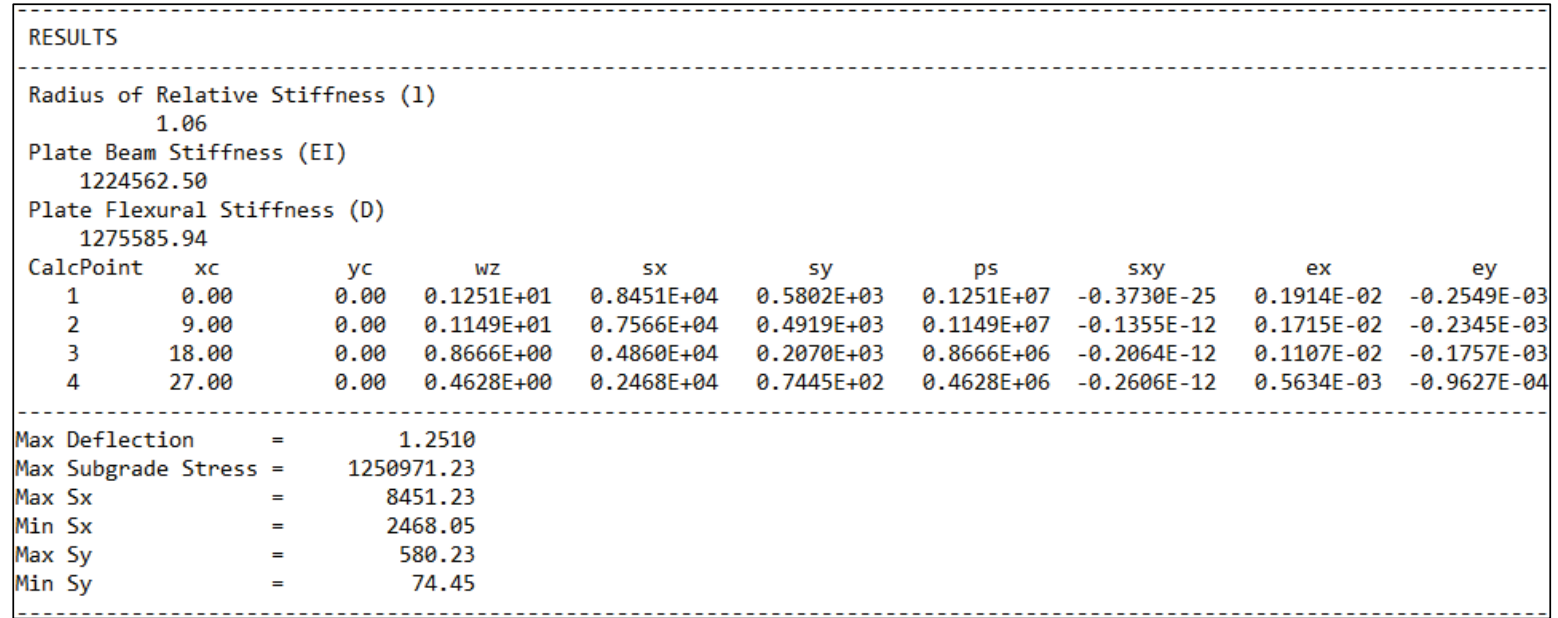




\section{Results and Analysis}

Example results can be found in Figure 4.1, which shows a plot of the deflection data recorded during a field test on one panel of AM2. Each load increment is labeled in the plot. Figure 4.2 is a linear representation of the data shown in Figure 4.1, where deflection was plotted against the applied load for each gauge. Note LVDT_1 was placed at the midpoint and LVDT_4 was closest to the support. The data for the remainder of the matting systems tested are shown in Appendices A and B.

Note how the curves in Figure 4.2 have a non-linear behavior during the first load increments and then continue with a linear behavior. This was observed for all testing configurations and was due to slack in the system at the beginning of the test. Since the maximum deflection was used for back-calculation purposes, the non-linear behavior did not affect the modulus and flexural rigidity determined using the plate theory.

Figure 4.1. AM2 single panel test recorded deflection data (72-in. span).

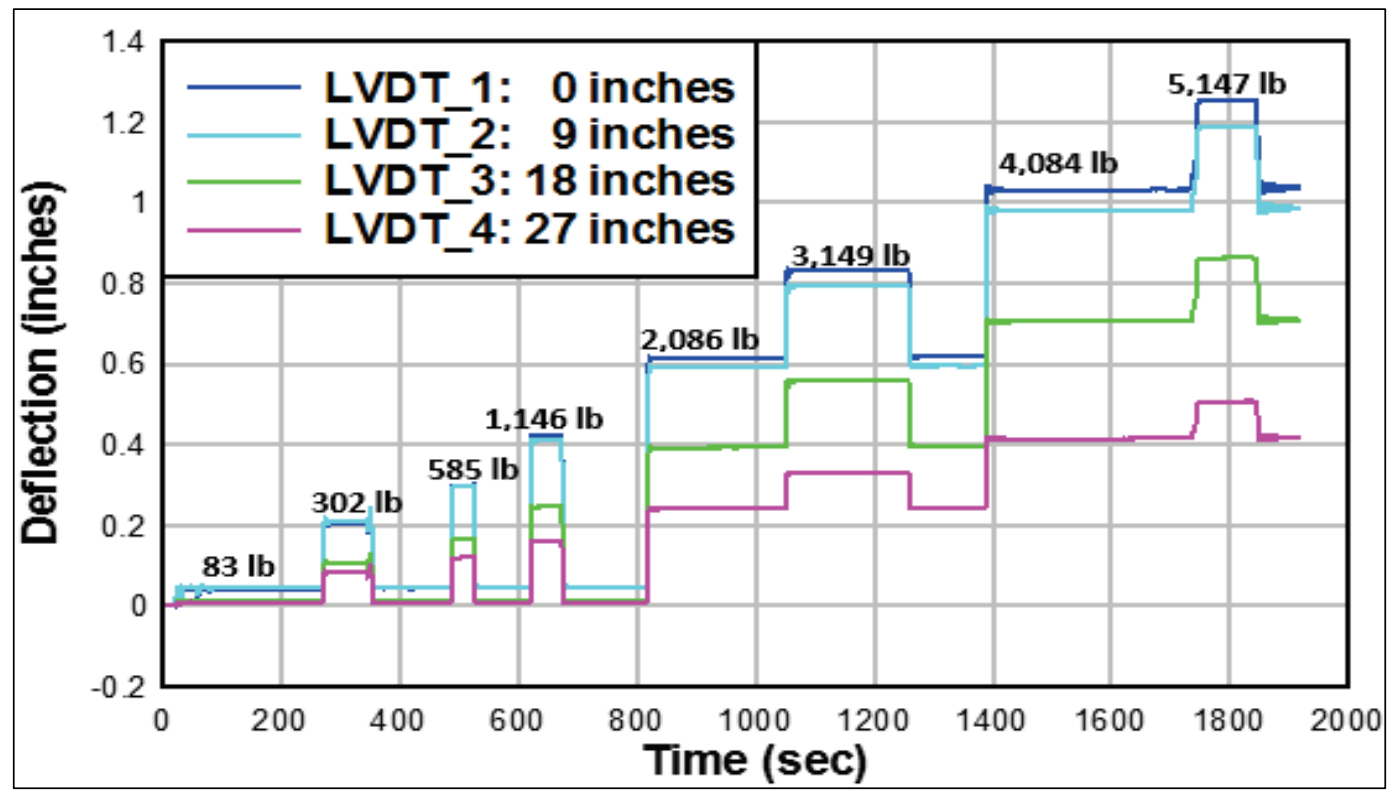


Figure 4.2. AM2 single panel test, deflection vs load plot (72-in. span).

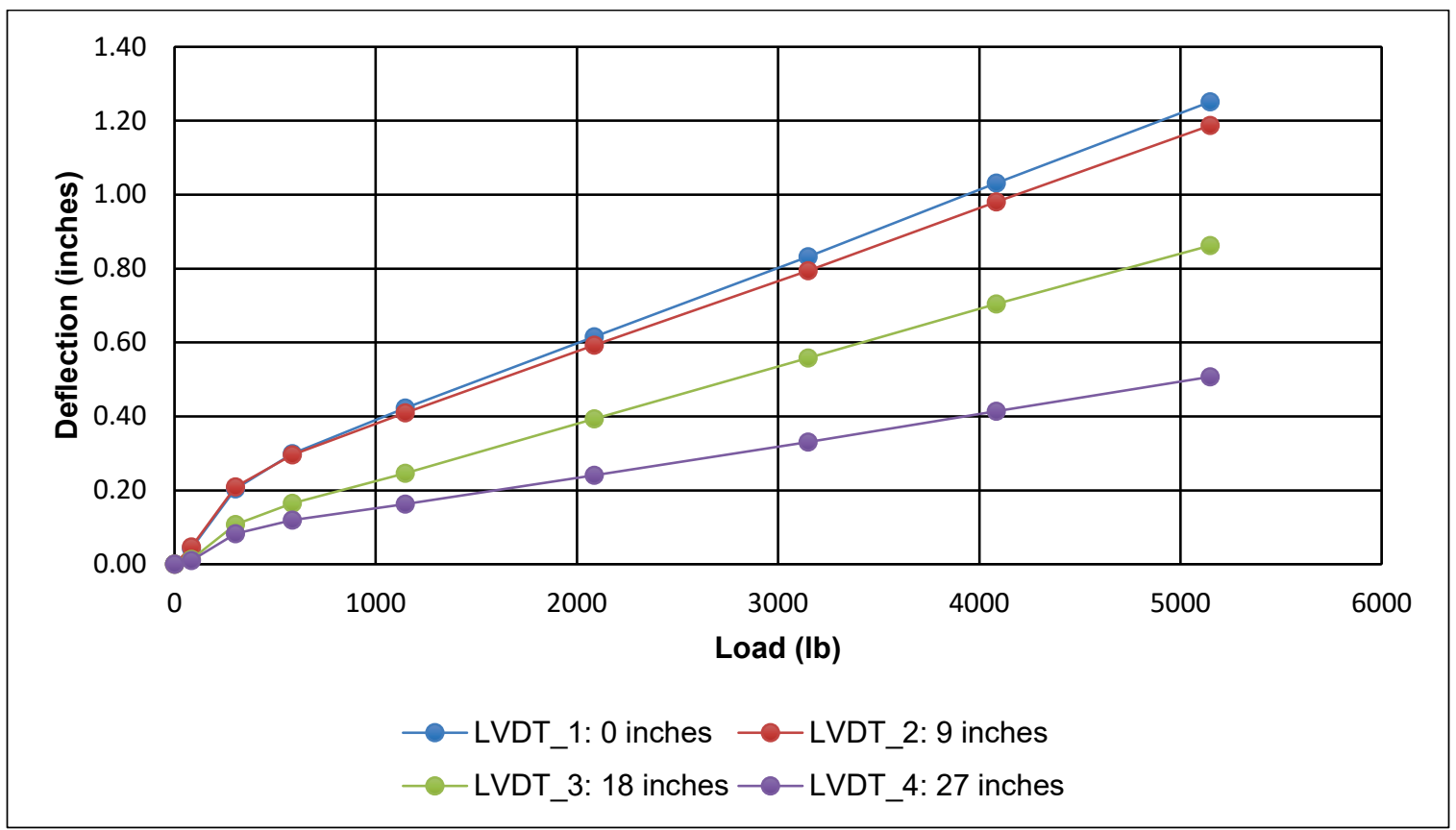

Table 4.1 shows the results of the Mindlin plate solution for all of the mats and test configurations. The best structural properties were exhibited by AM2 with a modulus of elasticity of over 4,00o ksi and a flexural rigidity of around 1,200 kips-in., for both single and multiple panel configurations. These results were expected since AM2 outperformed all other matting systems in field dynamic trafficking tests in terms of passes-to-failure on a CBR of 6 (Rushing and Tingle 2007). ALMATS had a modulus of elasticity very close to that of $\mathrm{AM} 2$, but the flexural rigidity was about $30 \%$ of that of AM2 because of the reduced overall thickness. The thick vertical members of the ALMATS core could have contributed to the high modulus. PSA-FT$\mathrm{R}$ had the lowest modulus and flexural rigidity, which was expected because of the lack of the bottom skin, the narrow width, and the small thickness. The Modified Light-Duty AM2 showed the best flexural rigidity, other than AM2, because of the overall thickness (same as AM2) and the well-designed core. The vertical members of the Modified Light-Duty AM2 are thinner than those of AM2, which was the key contributor to the lower modulus. Although the S46 exhibited a high modulus that can be contributed to its wide width, the flexural rigidity was less than half of AM2's. 
Table 4.1. Back-calculated flexural rigidity for the mats tested.

\begin{tabular}{|c|c|c|c|c|c|c|c|c|c|c|}
\hline Mat & $\begin{array}{l}\text { Width } \\
\text { (in.) }\end{array}$ & $\begin{array}{l}\text { Length } \\
\text { (in.) }\end{array}$ & $\begin{array}{l}\text { Thickne } \\
\text { ss (in.) }\end{array}$ & \begin{tabular}{|l|} 
Unit \\
Surfac \\
e \\
Weight \\
(psf) \\
\end{tabular} & $\begin{array}{l}\text { No. of } \\
\text { Panels } \\
\text { Tested }\end{array}$ & $\begin{array}{l}\text { Supporting } \\
\text { Beam } \\
\text { Distance } \\
\text { (in.) }\end{array}$ & $\begin{array}{l}\text { Modulus } \\
\text { (ksi) }\end{array}$ & $\begin{array}{l}\% \text { of } \\
\text { AM2 }\end{array}$ & $\begin{array}{l}\text { Flexural } \\
\text { Rigidity } \\
\text { (kips-in.) }\end{array}$ & $\%$ of $A M 2$ \\
\hline \multirow{4}{*}{ AM2 } & \multirow{4}{*}{24.00} & \multirow{4}{*}{144.00} & \multirow{4}{*}{1.50} & \multirow{4}{*}{6.10} & 1 & 72 & 4,354 & - & 1,275 & - \\
\hline & & & & & 3 & 72 & 4,291 & - & 1,257 & - \\
\hline & & & & & 1 & 120 & 4,108 & - & 1,203 & - \\
\hline & & & & & 3 & 120 & 4,533 & - & 1,328 & - \\
\hline \multirow{3}{*}{ PSA-FT-R } & \multirow{3}{*}{10.38} & \multirow{3}{*}{103.69} & \multirow{3}{*}{0.92} & \multirow{3}{*}{3.50} & 1 & 72 & 2,267 & $52 \%$ & 153 & $12 \%$ \\
\hline & & & & & 3 & 72 & 2,544 & $59 \%$ & 171 & $14 \%$ \\
\hline & & & & & 6 & 72 & 2,443 & - & 165 & - \\
\hline \multirow{2}{*}{ ALMATS } & \multirow{2}{*}{20.00} & \multirow{2}{*}{103.44} & \multirow{2}{*}{1.00} & \multirow{2}{*}{3.97} & 1 & 72 & 4,222 & $97 \%$ & 366 & $29 \%$ \\
\hline & & & & & 3 & 72 & 4,516 & $105 \%$ & 392 & $31 \%$ \\
\hline \multirow{2}{*}{$\begin{array}{l}\text { Modified } \\
\text { Light-Duty } \\
\text { AM2 }\end{array}$} & \multirow{2}{*}{21.00} & \multirow{2}{*}{102.00} & \multirow{2}{*}{1.50} & \multirow{2}{*}{4.00} & 1 & 72 & 2,987 & $69 \%$ & 875 & $69 \%$ \\
\hline & & & & & 3 & 72 & 3,186 & $74 \%$ & 933 & $74 \%$ \\
\hline \multirow{2}{*}{ S46 } & \multirow{2}{*}{41.75} & \multirow{2}{*}{83.50} & \multirow{2}{*}{1.17} & \multirow{2}{*}{4.29} & 1 & 60 & 4,115 & $95 \%$ & 572 & $45 \%$ \\
\hline & & & & & 3 & 60 & 4,018 & $94 \%$ & 558 & $44 \%$ \\
\hline
\end{tabular}

The results obtained from this test program generally agreed with field performance. In full-scale testing described by Garcia et al. (2017), ALMATS performed better compared to the PSA-FT-R when trafficked under RPA loads. Notably, the ALMATS had a flexural rigidity of 392 kipsin. for the multiple panel configuration compared to 171 kips-in. for the PSA-FT-R. Additionally, Hoffman et al. (2018) reported that the Modified Light-Duty AM2 provided excellent performance with RPA loads. Garcia and Hoffman (2018) reported poor performance of the S46 and ALMATS when tested on a CBR of 6 and trafficked under F-15E traffic. Fewer than 50 passes to failure were supported by either mat system. Similarly, the Modified Light-Duty AM2 performed poorly with just over 100 passes for a reduced F-15E load over a 6 CBR subgrade (Hoffman and Garcia 2018). The results shown in Table 4.1 suggest that the full-scale performance of the Modified Light-Duty AM2 should have been closer to AM2's; however, the simply supported beam test does not consider the properties of the joint at the short end, which was where most failures of the S46, ALMATS, and Modified Light-Duty AM2 mat systems occurred during full-scale testing. This is a limitation of the testing program described in this report in characterizing airfield mat structural properties. Different end connectors and joint styles limit the direct comparison of core structural 
characteristics. Additional testing for characterization of joint performance at a laboratory scale should be performed to fully understand the relationship between measured structural properties and field performance under different dynamic load. Rushing et al. (2016) developed a laboratory experiment that seems promising in accomplishing this objective, but it is still limited to F-15E loading conditions. 


\section{Conclusions}

This report presented data collected from a medium-scale simply supported bending test performed on new matting systems that were previously evaluated in full-scale test sections under the AMX and RPA lightweight mat programs. The experiments were performed to determine the structural properties of the new matting and compare the data to the AM2 airfield mat system properties.

The experiments involved putting a panel on a simply supported beam setup with four deflection gauges placed underneath the mat panel from the support to midspan, while the panel was incrementally loaded at midspan. Deflection data were recorded continuously by a computer program for the duration of the test to capture the responses of the mat panels during all loading and unloading cycles. Mats were tested in single and multiple panel configurations to evaluate the influence of the panel transverse joint system. The unit section modulus and flexural stiffness were back-calculated by using the finite element implementation of the Mindlin plate solution.

Based on the comparison and analysis of results, the following conclusions were developed:

1. AM2 mat exhibited the best structural properties compared to the lightweight mat systems. The weakest system in terms of flexural rigidity was PSA-FT-R, since it did not have a bottom skin and had the thinnest, narrowest cross section of the mats investigated. ALMATS and S46 had moduli close to AM2's modulus, but had lower flexural rigidity because of their reduced thickness. The Modified Light-Duty AM2 system exhibited good structural properties compared to those of AM2.

2. Structural properties determined through the test program described in this report generally agreed with full-scale performance of the matting systems under dynamic loading. However, the experiments are limited in that they do not characterize the joint on the longitudinal end of the mat panels. Characterization requires additional laboratory testing of joint fatigue performance to fully understand the relationship between structural properties and performance under dynamic loads.

3. The data collected in this test program can potentially be used to refine design curves developed for predicting airfield mat performance under 
F-15E aircraft traffic. It can also be used to create curves for predicting subgrade soil deformation resulting from RPA aircraft. This information is useful for conducting preliminary analyses of alternative mat systems in order to mitigate the costs associated with full-scale testing of new submittals.

4. The measured/calculated flexural rigidity of the matting systems was the most significant indicator of performance under heavy aircraft loads. Mats with higher values are less subjective to bending and permanent deformation; however, the loading applied (i.e. aircraft type) must be considered when selecting the proper matting system to support aircraft operations. 


\section{References}

Berney, E. S., W. D. Hodo, and J. A. Vera. 2006. Determination of unit section modulus for finite element modeling of matting systems. ERDC/GSL TR-06-10. Vicksburg, MS: U.S. Army Engineer Research and Development Center.

Garcia, L., and I. L. Howard. 2016. Full-scale instrumented testing of multiple airfield matting systems on soft soil to characterize permanent deformation.

Transportation Geotechnics 9:80-95.

Garcia, L., and N. Hoffman. 2018. Evaluation of lightweight airfield matting for the AMX program. ERDC/GSL TR-18-13. Vicksburg, MS: U.S. Army Engineer Research and Development Center.

Garcia, L., T. W. Rushing, and C. A. Rutland. 2017. Evaluation of expedient surfaces for remote piloted aircraft. ERDC/GSL TR-17-27. Vicksburg, MS: U.S. Army Engineer Research and Development Center.

Garcia, L., T. W. Rushing, and Q. S. Mason. 2012. Evaluation of Webcore prototype AMX mat system. ERDC/GSL TR-12-14. Vicksburg, MS: U.S. Army Engineer Research and Development Center.

Garcia, L., T. W. Rushing, Q. Mason, J. S. Tingle, and C. A. Rutland. 2015. AM2 mat end connector modeling and performance validation. ERDC/GSL TR-15-28. Vicksburg, MS: U.S. Army Engineer Research and Development Center.

Gonzalez, C. R., and T. W. Rushing. 2010. Development of a new design methodology for structural airfield mats. International Journal of Pavement Research and Technology 3(3):102-109.

Hoffman, N., and L. Garcia. 2018. Modified Light-Duty AM2 capability assessment. ERDC/GSL TR-18-10. Vicksburg, MS: U.S. Army Engineer Research and Development Center.

Hoffman, N., L. Garcia, T. W. Rushing, J. B. Jordon, and P. G. Allison. 2018. Development and evaluation of Modified Light-Duty AM2 airfield matting. ERDC/GSL TR-18-8. Vicksburg, MS: U.S. Army Engineer Research and Development Center.

Mindlin, R. D. 1951. Influence of rotatory inertia and shear on flexural motions of isotropic elastic plates. Journal of Applied Mechanics 18:31-38.

Rushing, T. W., and J. S. Tingle. 2007. AM2 and M19 airfield mat evaluation for the Rapid Parking Ramp Expansion Program. ERDC/GSL TR-07-5. Vicksburg, MS: U.S. Army Engineer Research and Development Center.

Rushing, T. W., I. L. Howard, J. B. Jordon, and P. G. Allison. 2016. Laboratory characterization of fatigue performance of AM2 aluminum airfield matting. Journal of Materials in Civil Engineering 28(11). 
Rushing, T. W., J. S. Tingle, and L. I. Garcia. 2009. Small-scale prototype mat system evaluation for the AMX program. ERDC/GSL TR-09-1. Vicksburg, MS: U.S. Army Engineer Research and Development Center.

Rushing, T. W., L. Garcia, and Q. S. Mason. 2012. Evaluation of Faun aluminum mat systems. ERDC/GSL TR-12-32. Vicksburg, MS: U.S. Army Engineer Research and Development Center. 


\section{Appendix A: Single Mats Results of Field Data}

This appendix shows the data for the single panel tests of the PSA-FT-R, ALMATS, Modified Light-Duty AM2, and S46 mat systems. Figures A.1 through A. 5 show the deflection data recorded during the tests. Figures A.6 through A.10 show the deflection plotted against the applied load.

Figure A.1. AM2 single panel test recorded deflection (120-in. span).

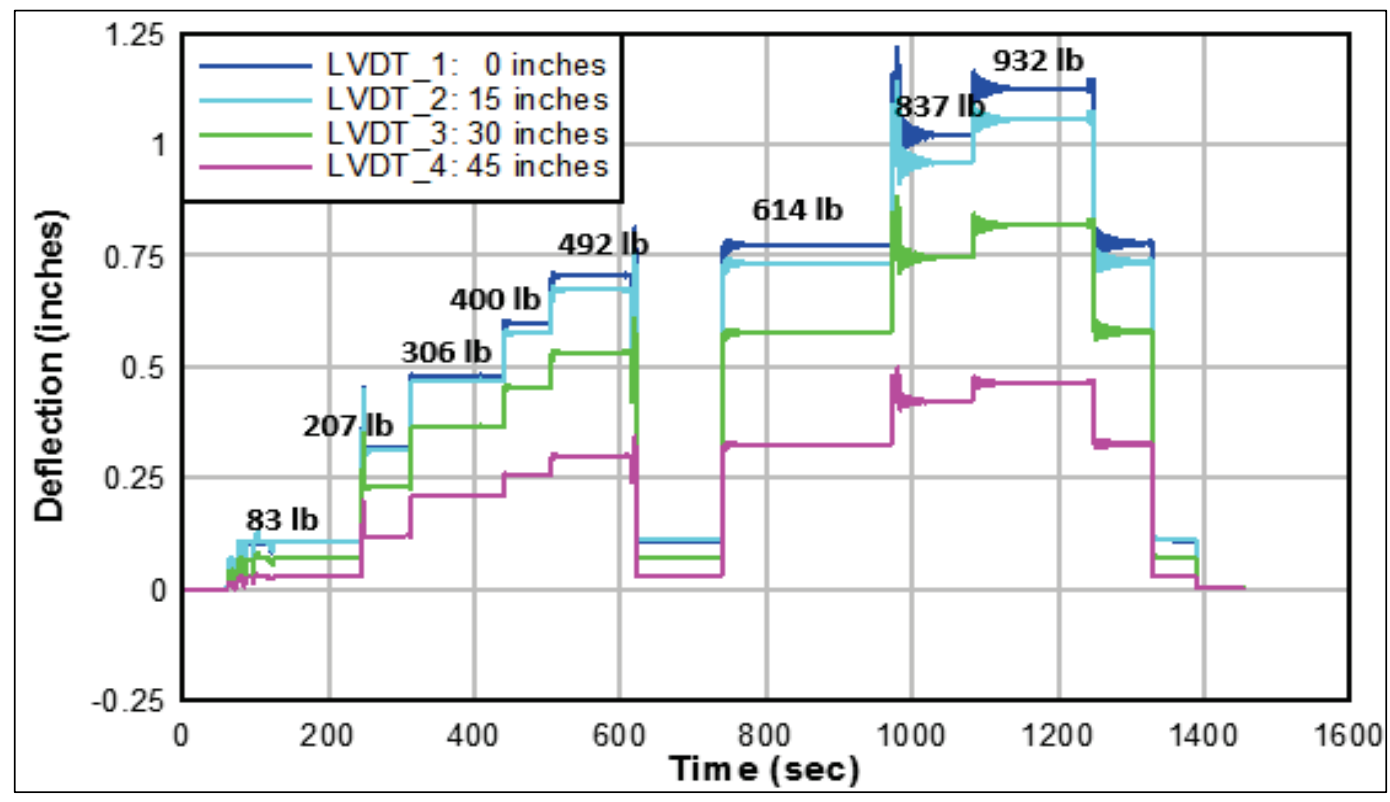

Figure A.2. ALMATS single panel test recorded deflection.

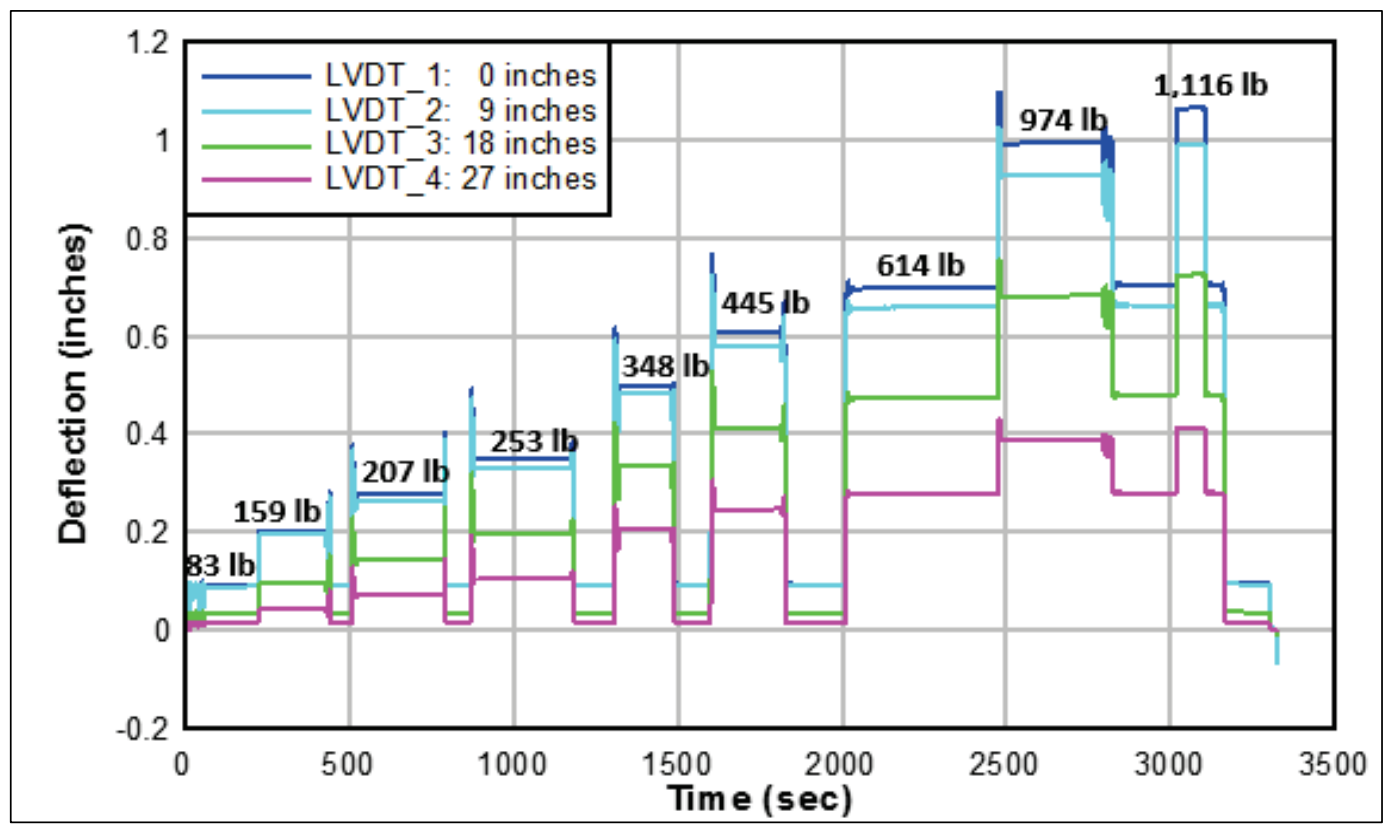


Figure A.3. PSA-FT-R single panel test recorded deflection.

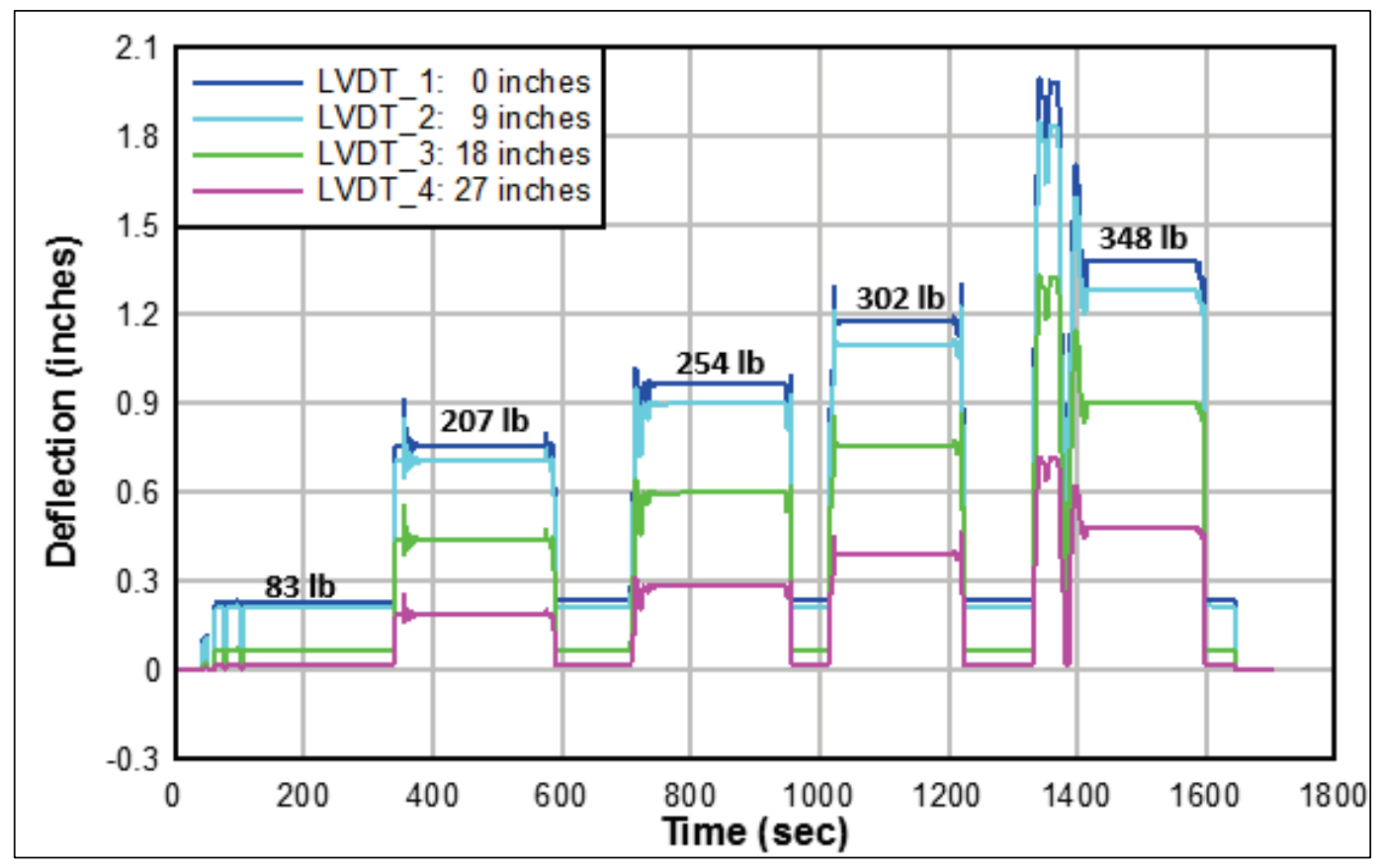

Figure A.4. Modified Light-Duty AM2 single panel test recorded deflection.

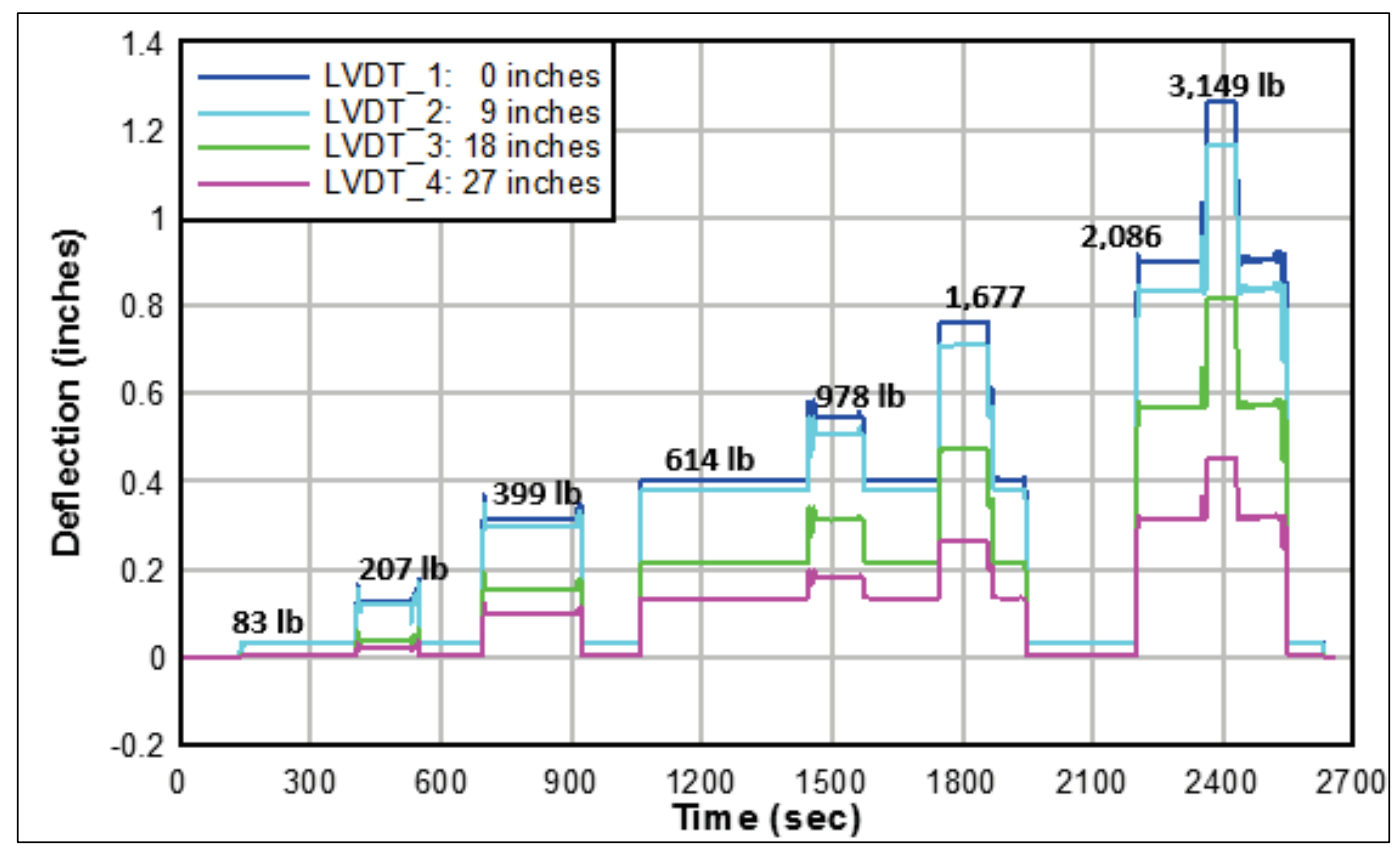


Figure A.5. S46 single panel test recorded deflection.

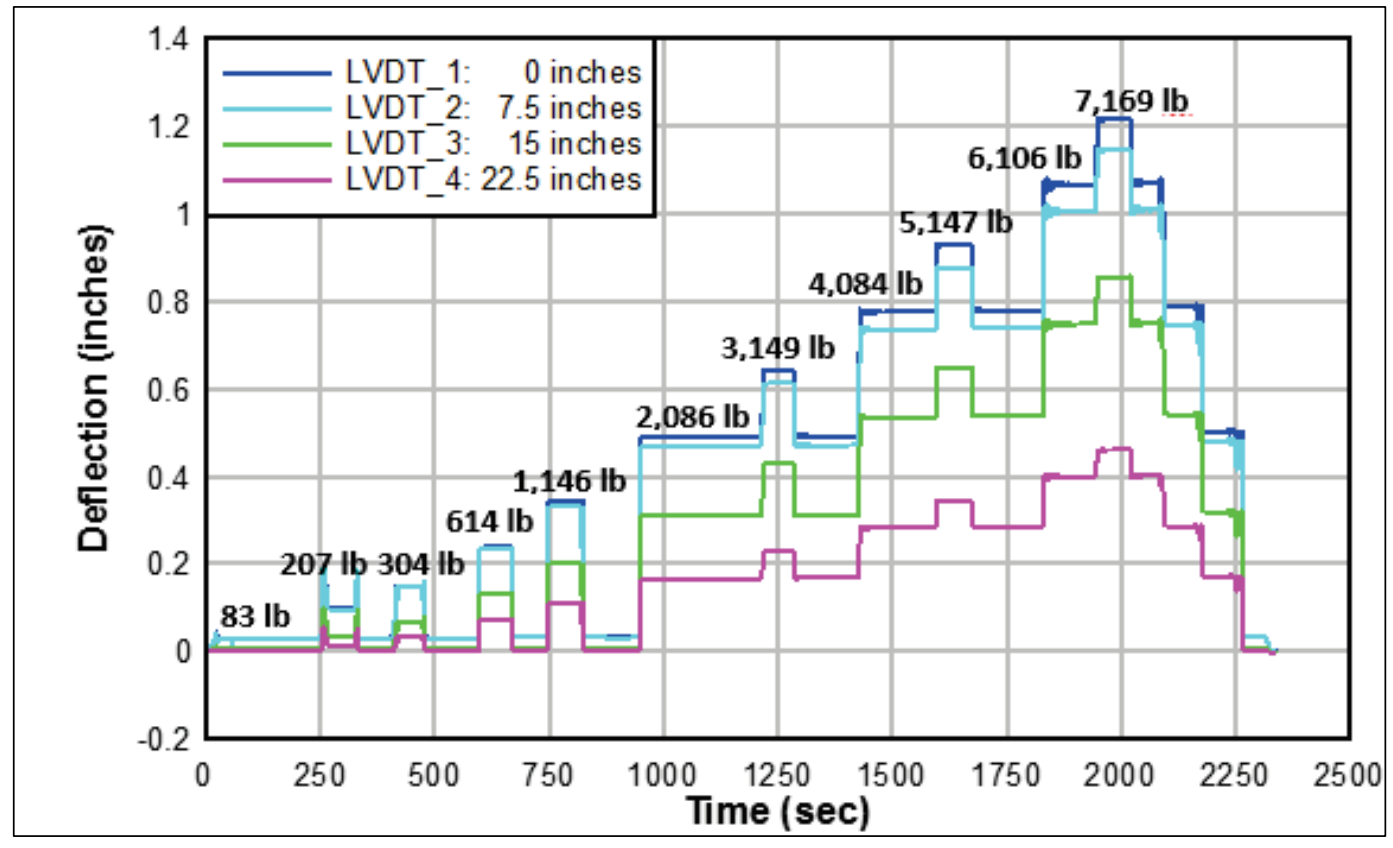

Figure A.6. AM2 single panel test, deflection vs load (120-in. span).

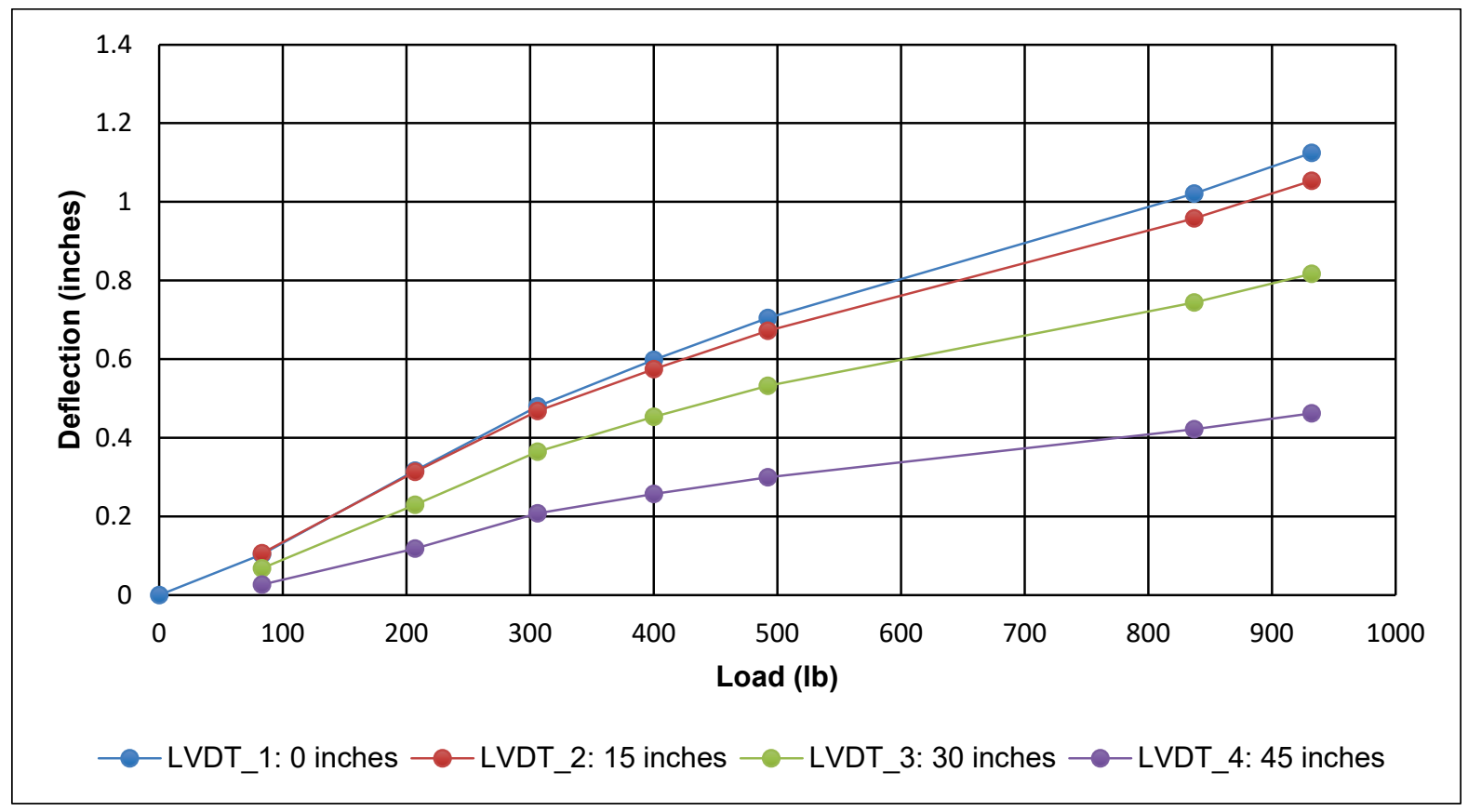


Figure A.7. ALMATS single panel test, deflection vs. load.

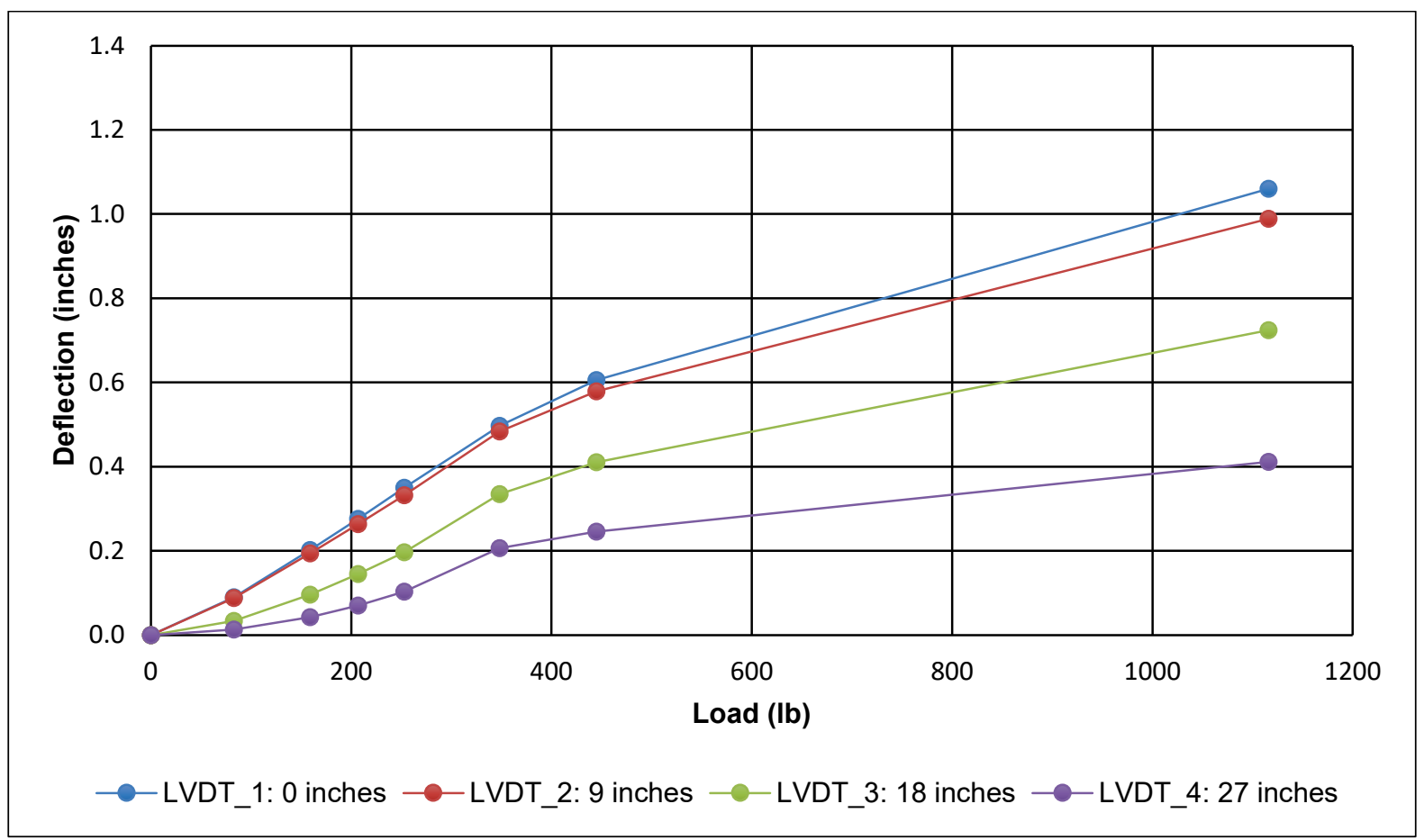

Figure A.8. PSA-FT-R single panel test, deflection vs. load.

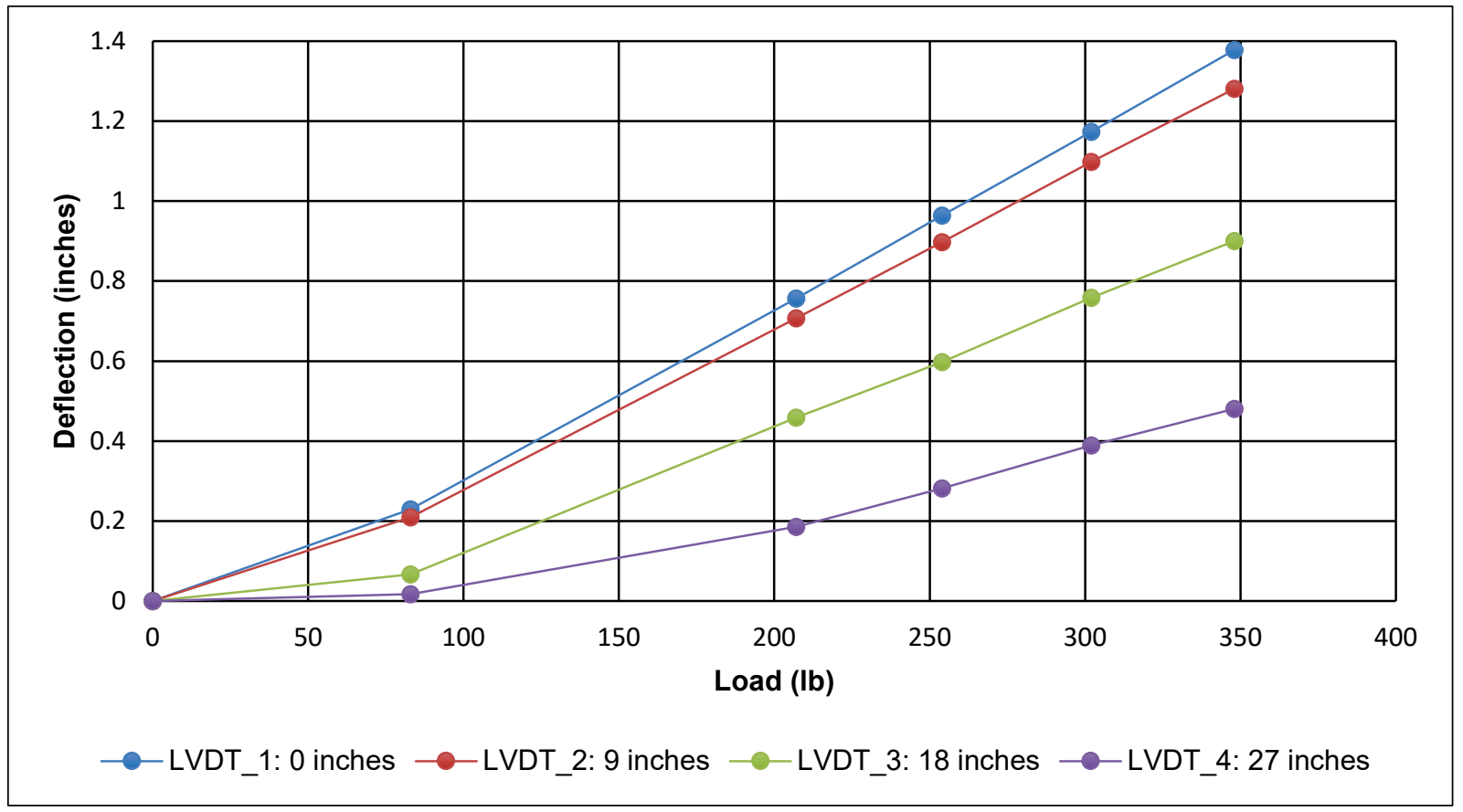


Figure A.9. Modified Light-Duty AM2 single panel test, deflection vs. load.

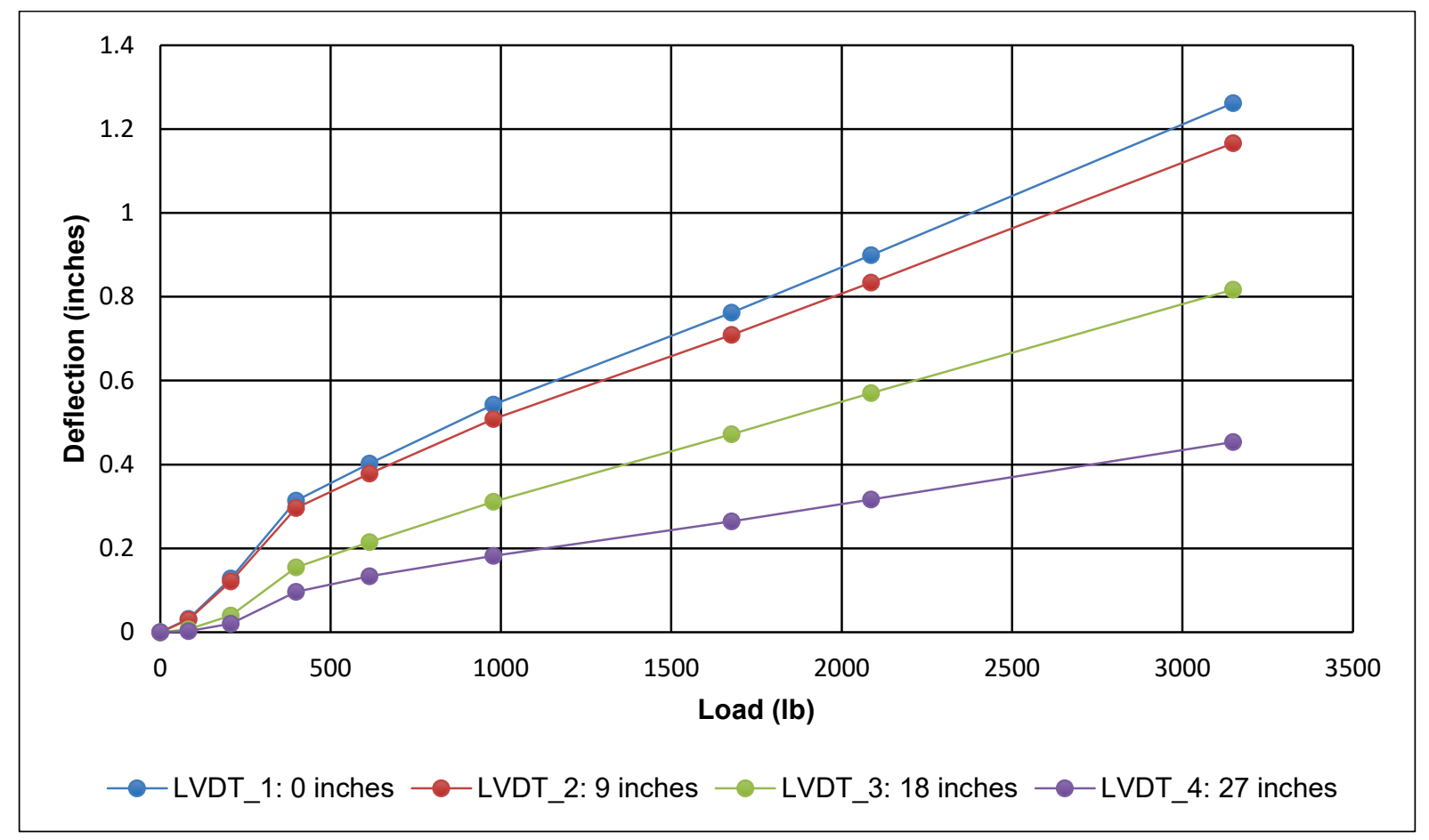

Figure A.10. S46 single panel test, deflection vs. load.

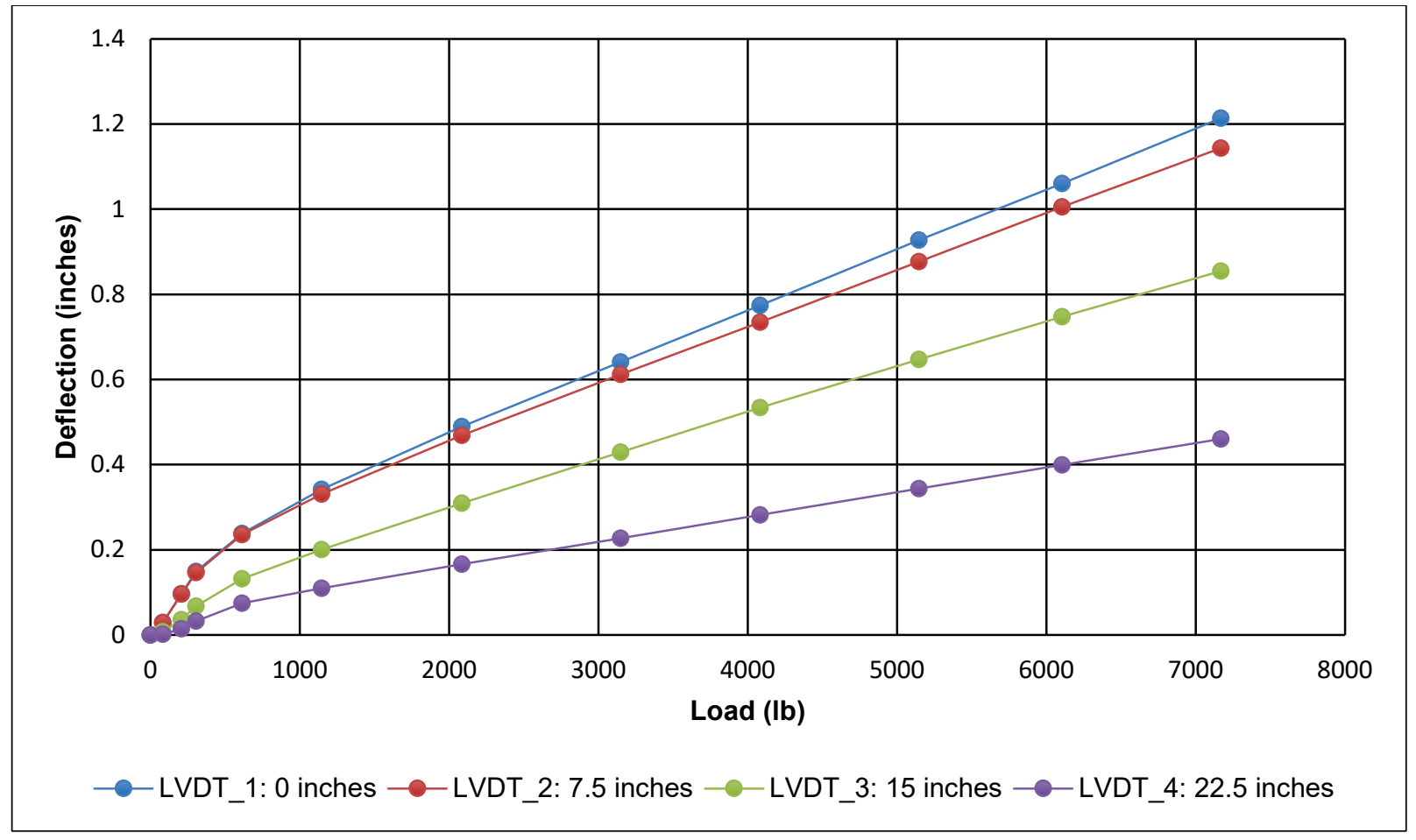




\section{Appendix B: Multiple Mats Results of Field Data}

This appendix shows the data for the multiple panel configuration tests of the PSA-FT-R, ALMATS, Modified Light-Duty AM2, and S46 mat systems. Figure B.1 through B.7 show the deflection data recorded during the tests. Figures B.8 through B.14 show the deflection plotted against the applied load.

Figure B.1. AM2 multiple panel test, recorded deflection (72-in. span).

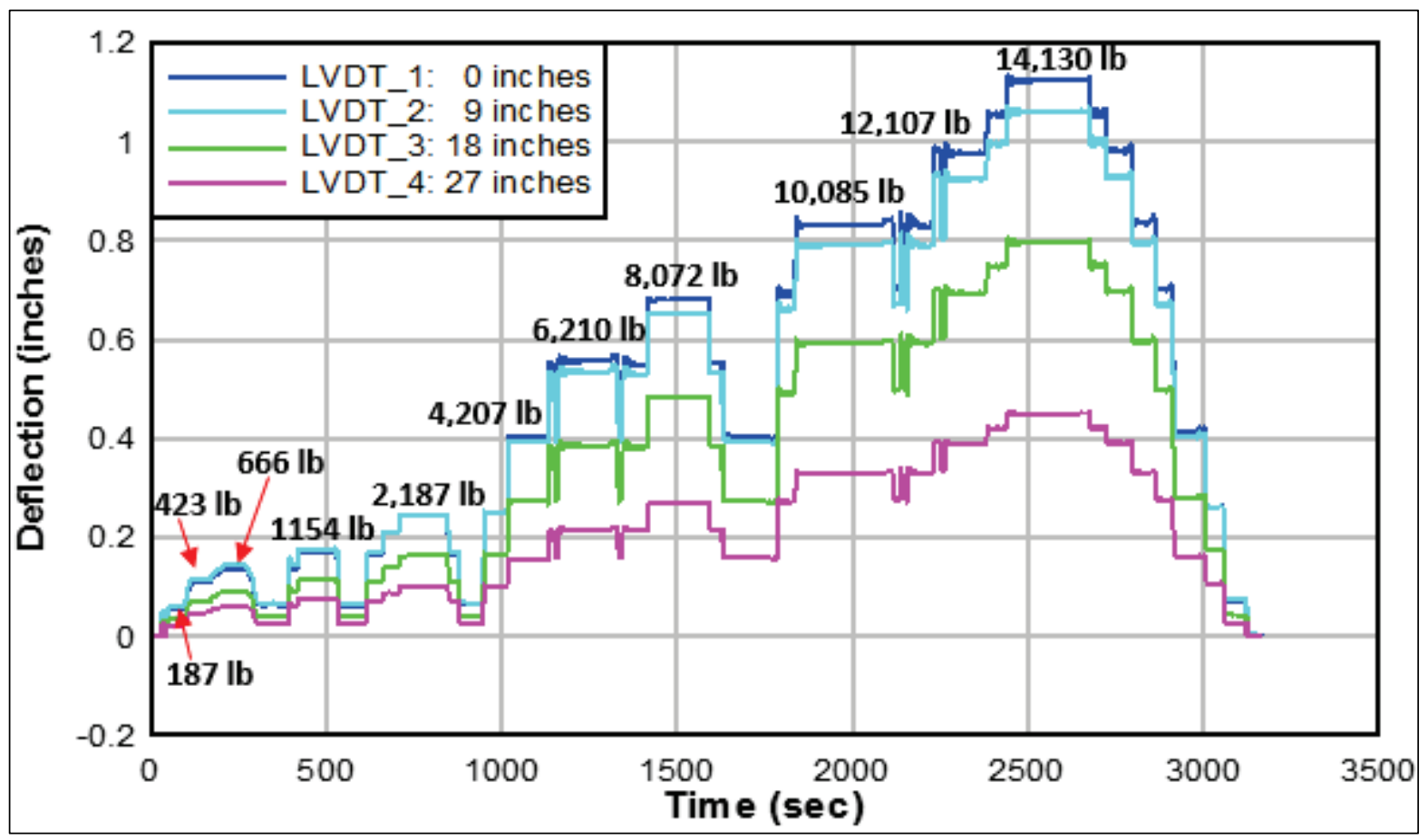


Figure B.2. AM2 multiple panel test, recorded deflection (120-in. span).

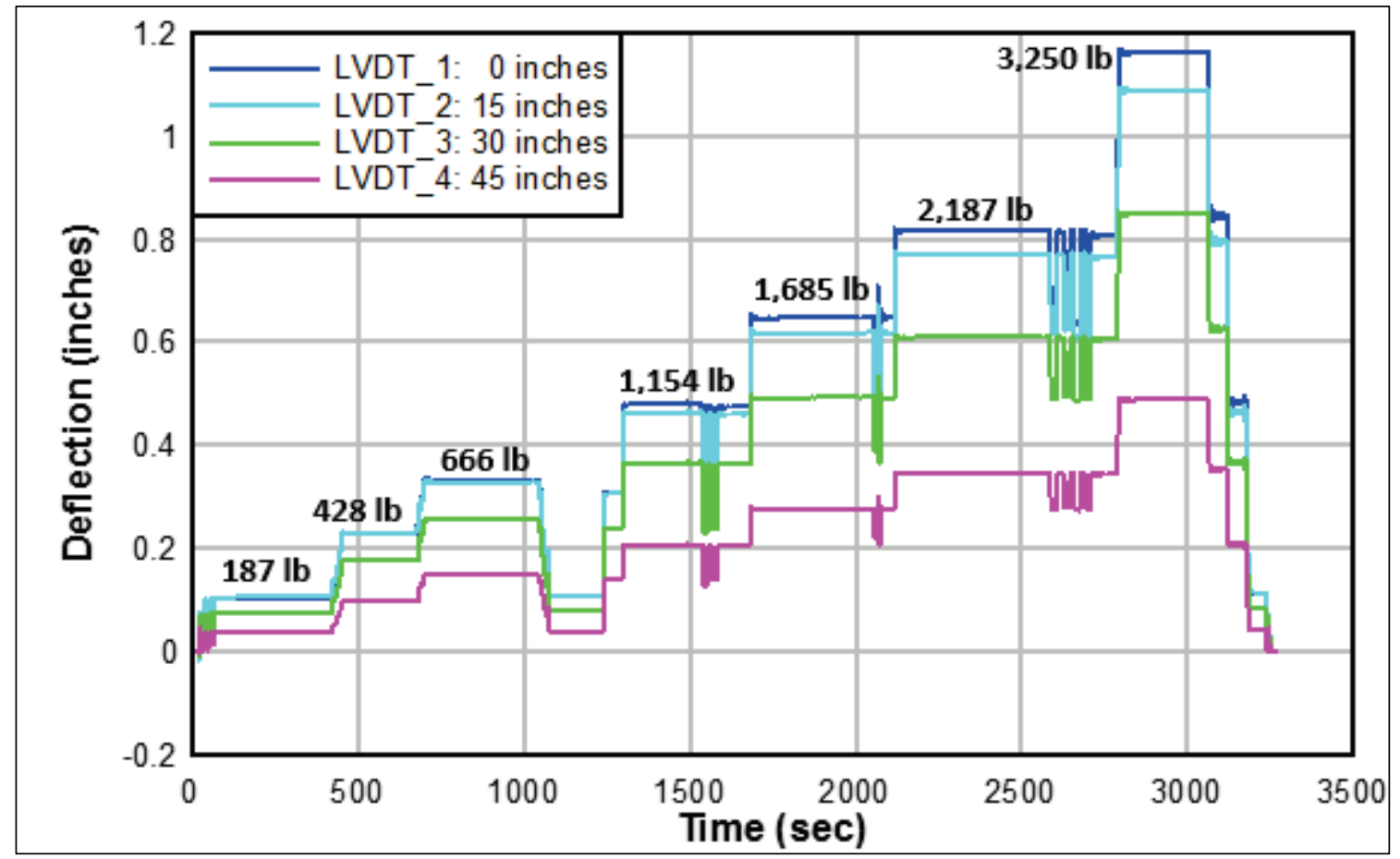

Figure B.3. ALMATS multiple panel test, recorded deflection.

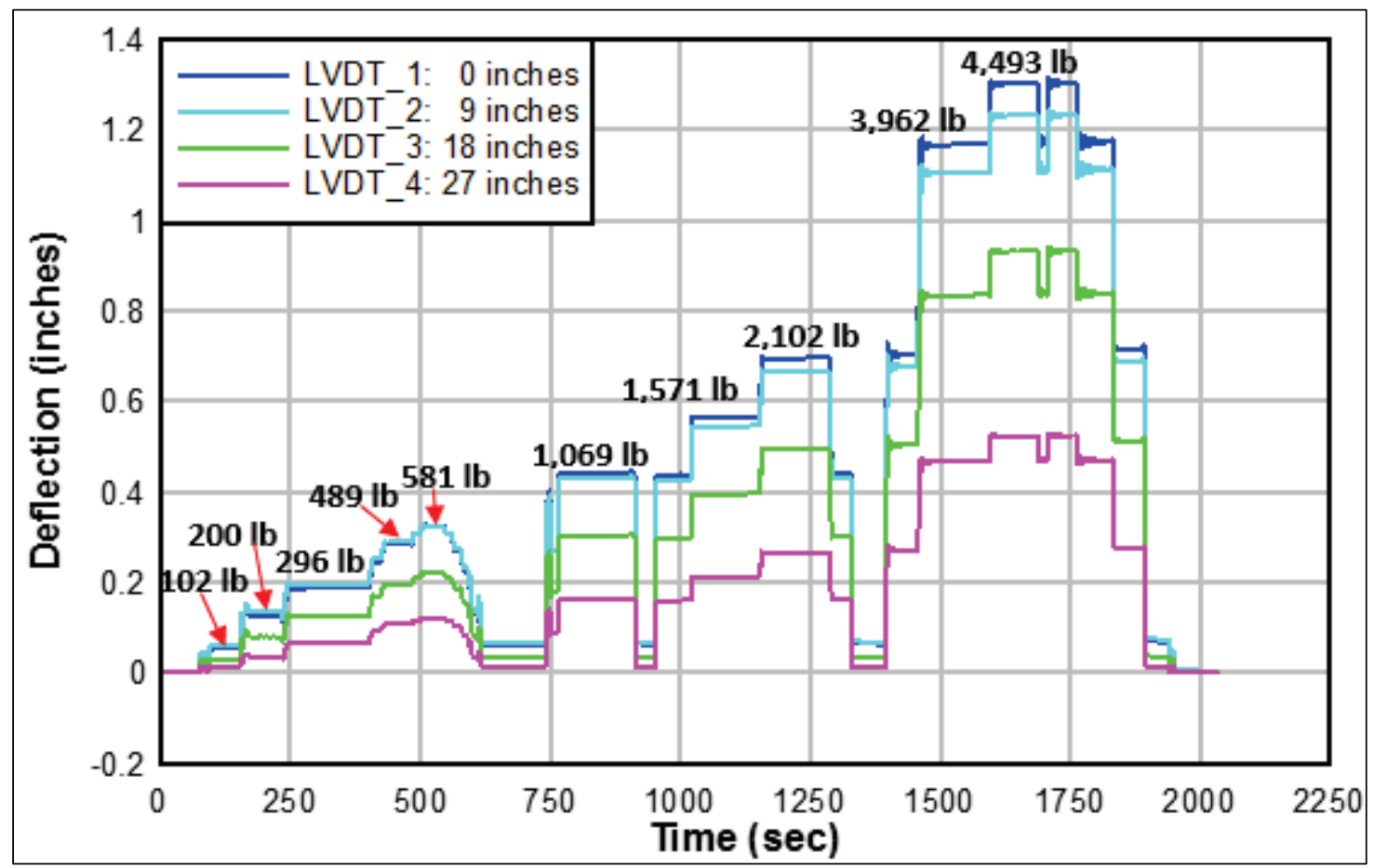


Figure B.4. PSA-FT-R multiple panel test, recorded deflection (3 panels).

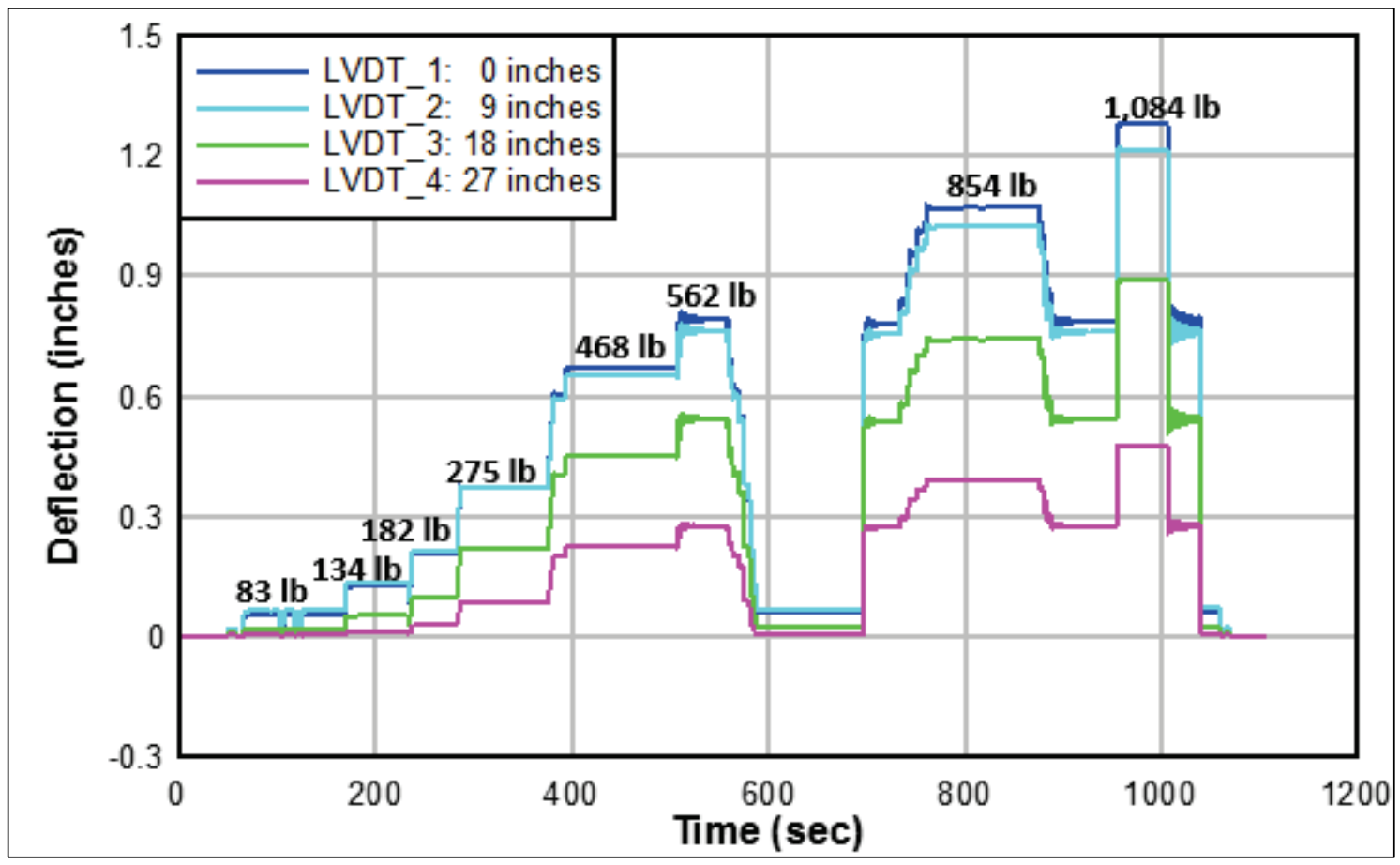

Figure B.5. PSA-FT-R multiple panel test, recorded deflection (6 panels).

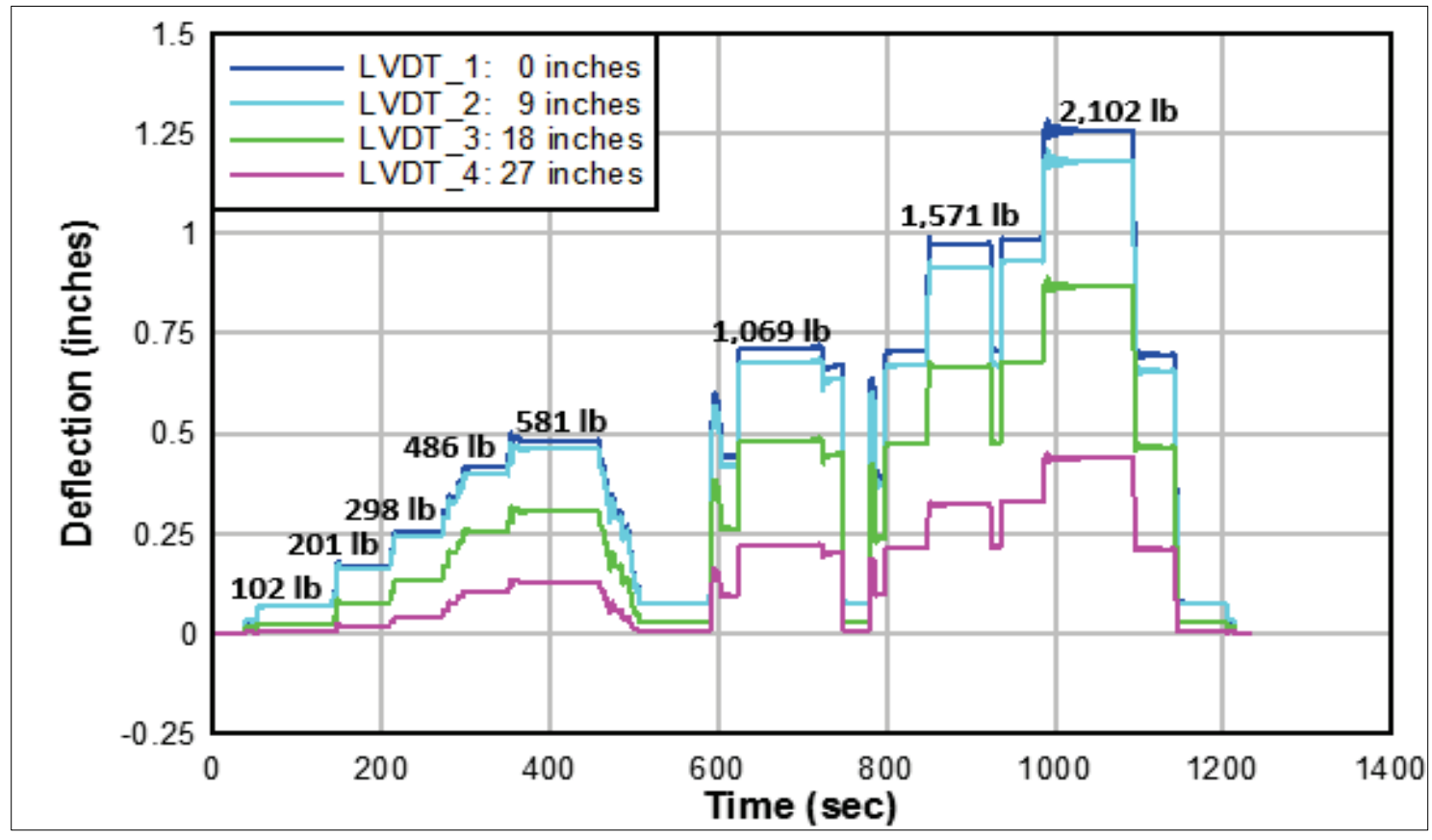


Figure B.6. Modified Light-Duty AM2 multiple panel test, recorded deflection.

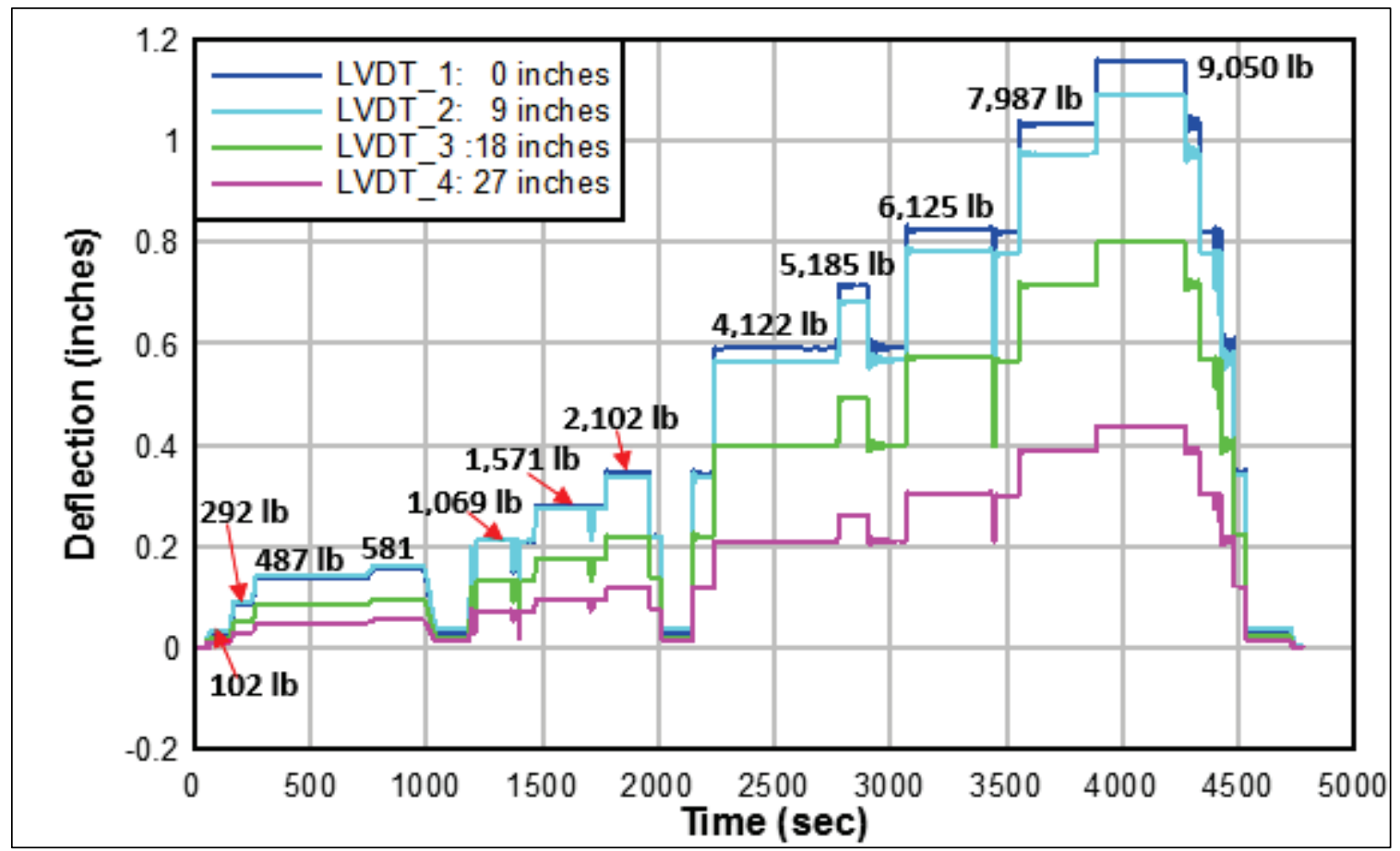

Figure B.7. S46 multiple panel test, recorded deflection.

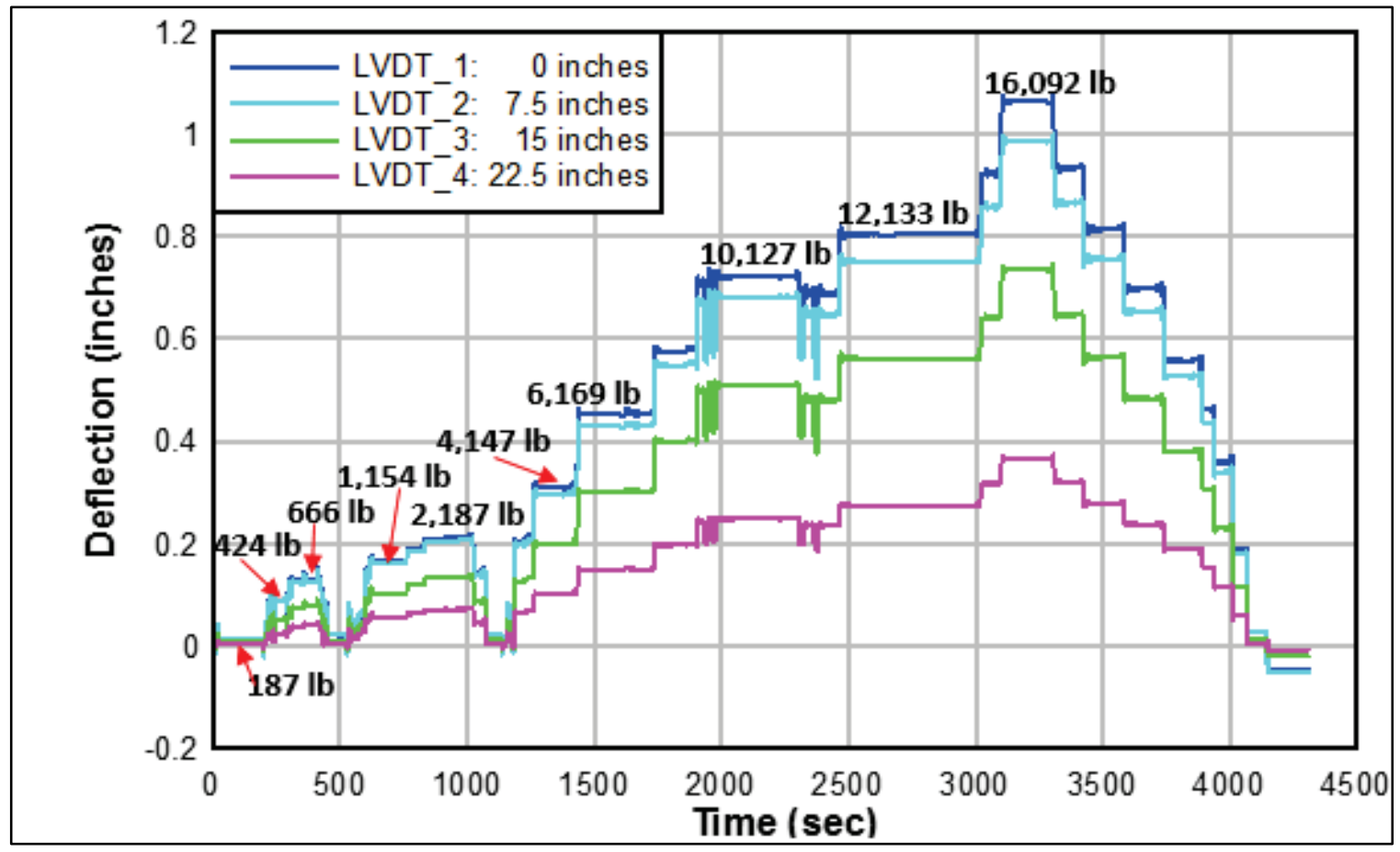


Figure B.8. AM2 multiple panel test, deflection vs. load (72-in. span)

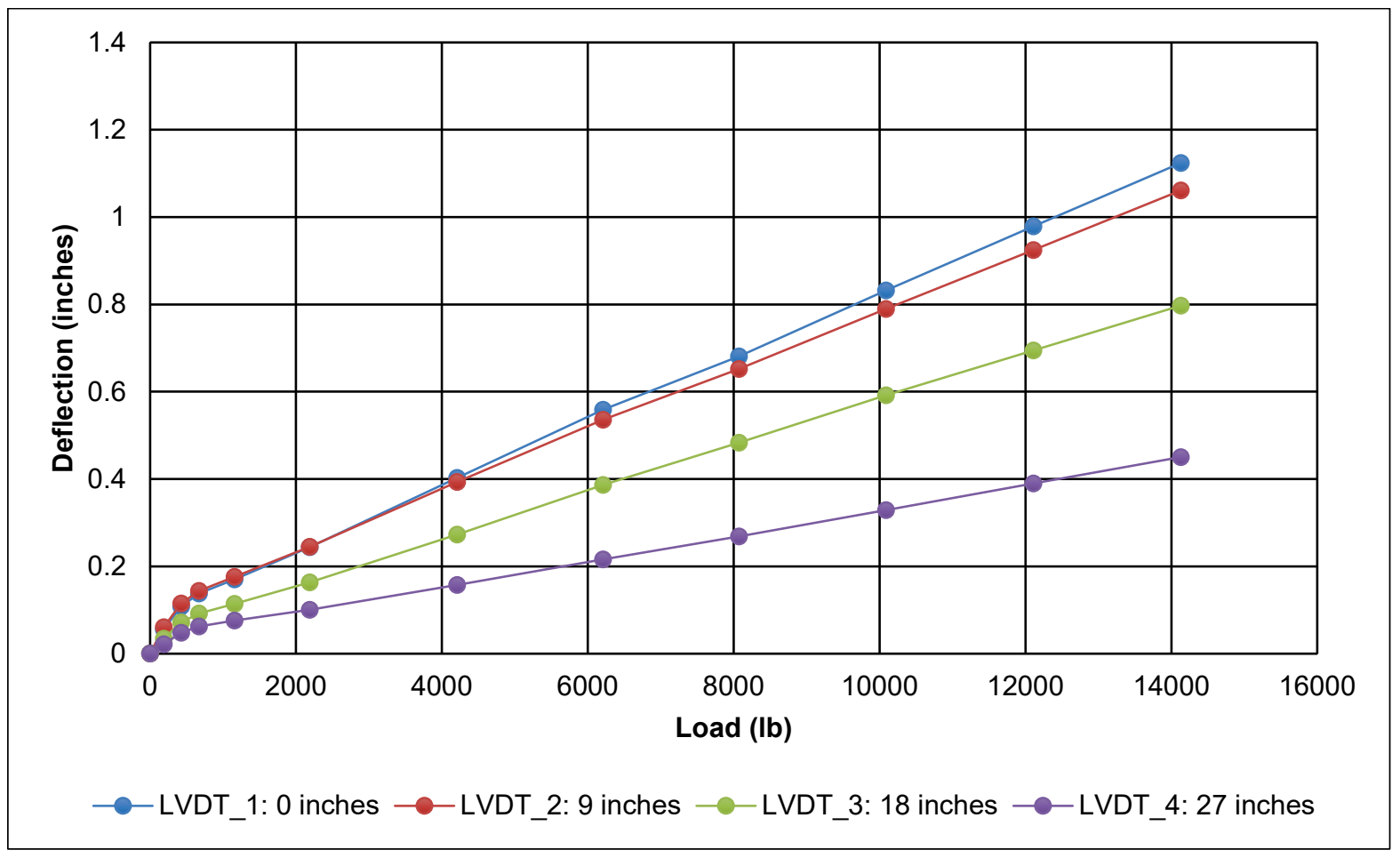

Figure B.9. AM2 multiple panel test, deflection vs. load (120-in. span)

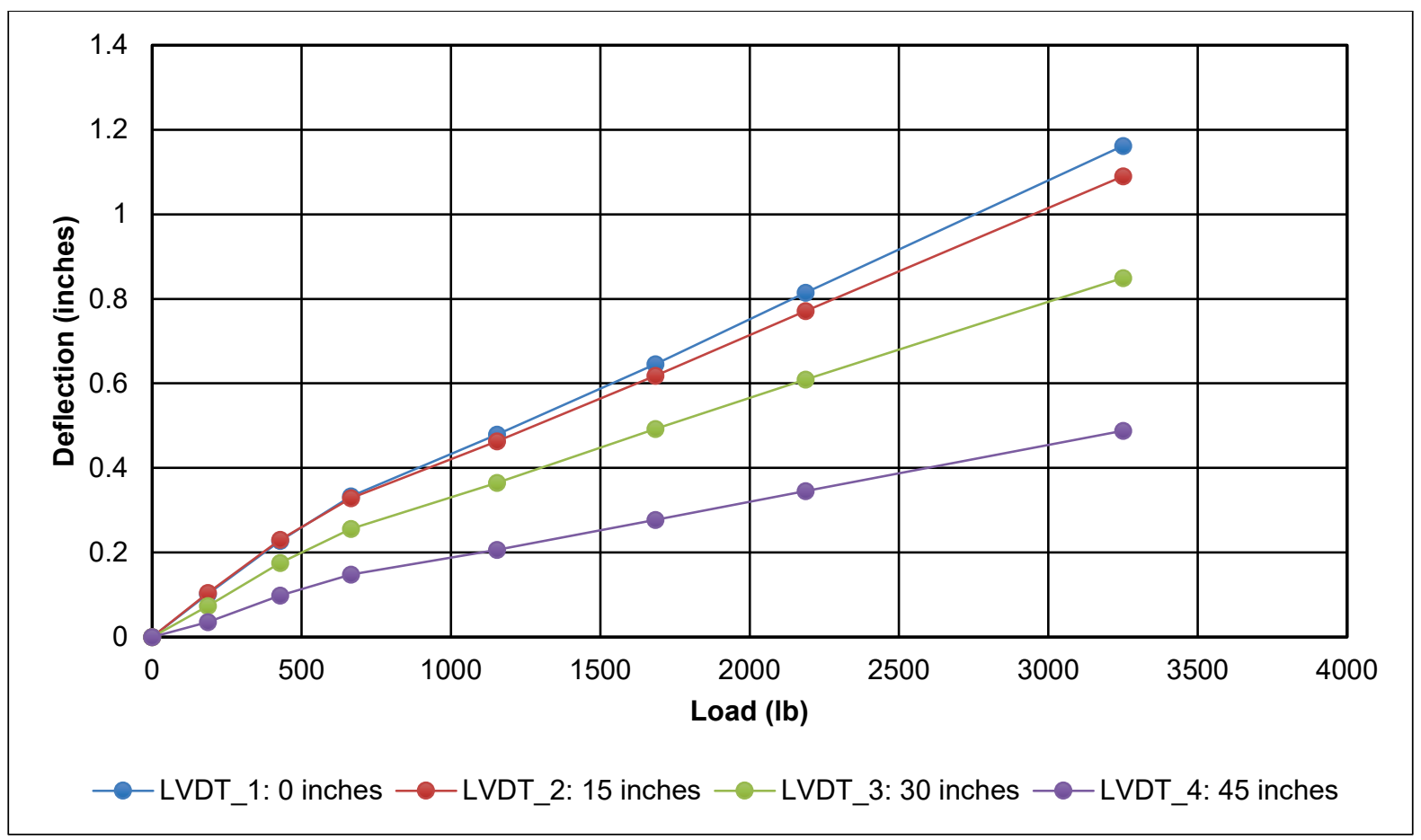


Figure B.10. ALMATS multiple panel test, deflection vs. load.

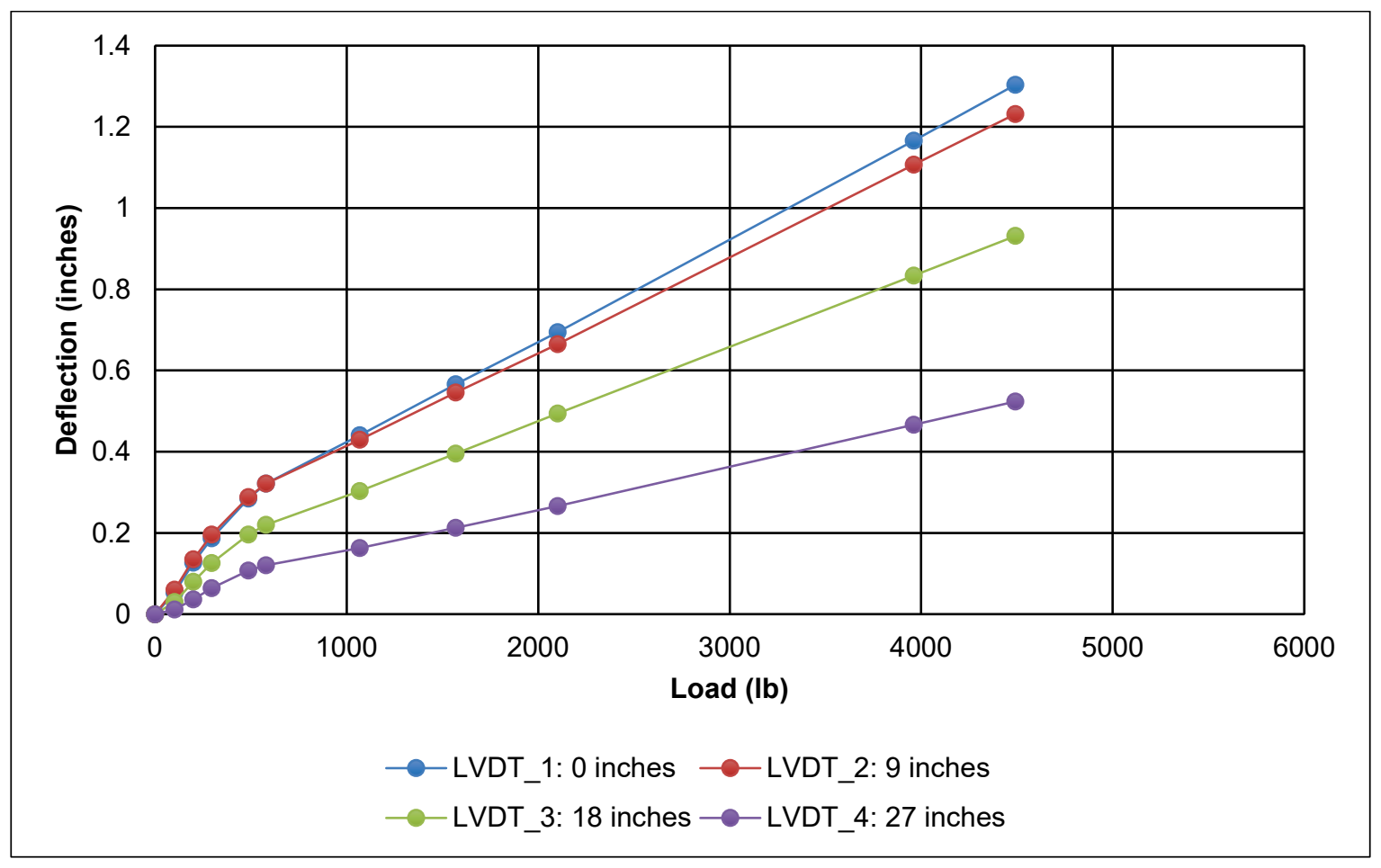

Figure B.11. Modified Light-Duty AM2 multiple panel test, deflection vs. load.

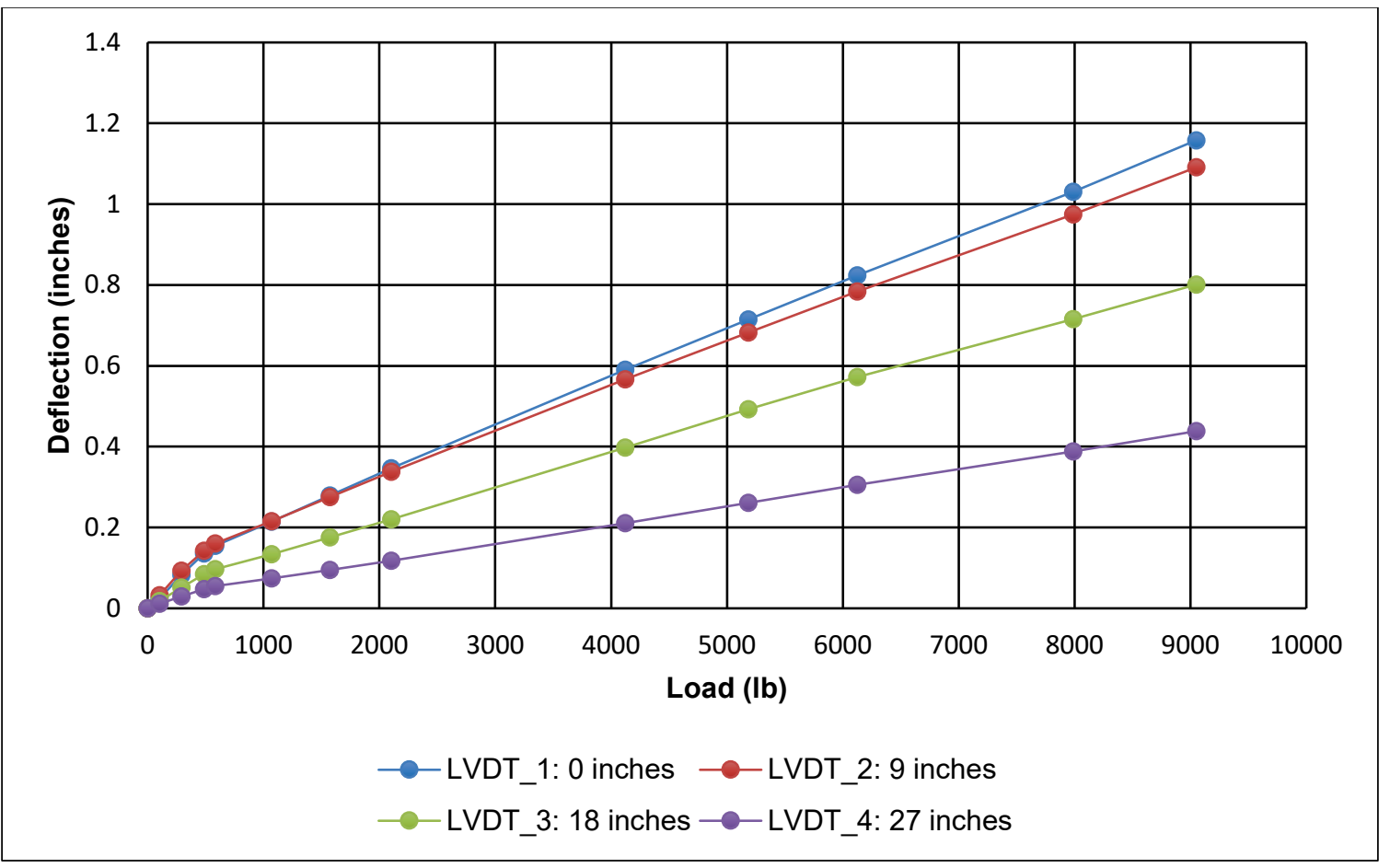


Figure B.12. S46 multiple panel test, deflection vs. load.

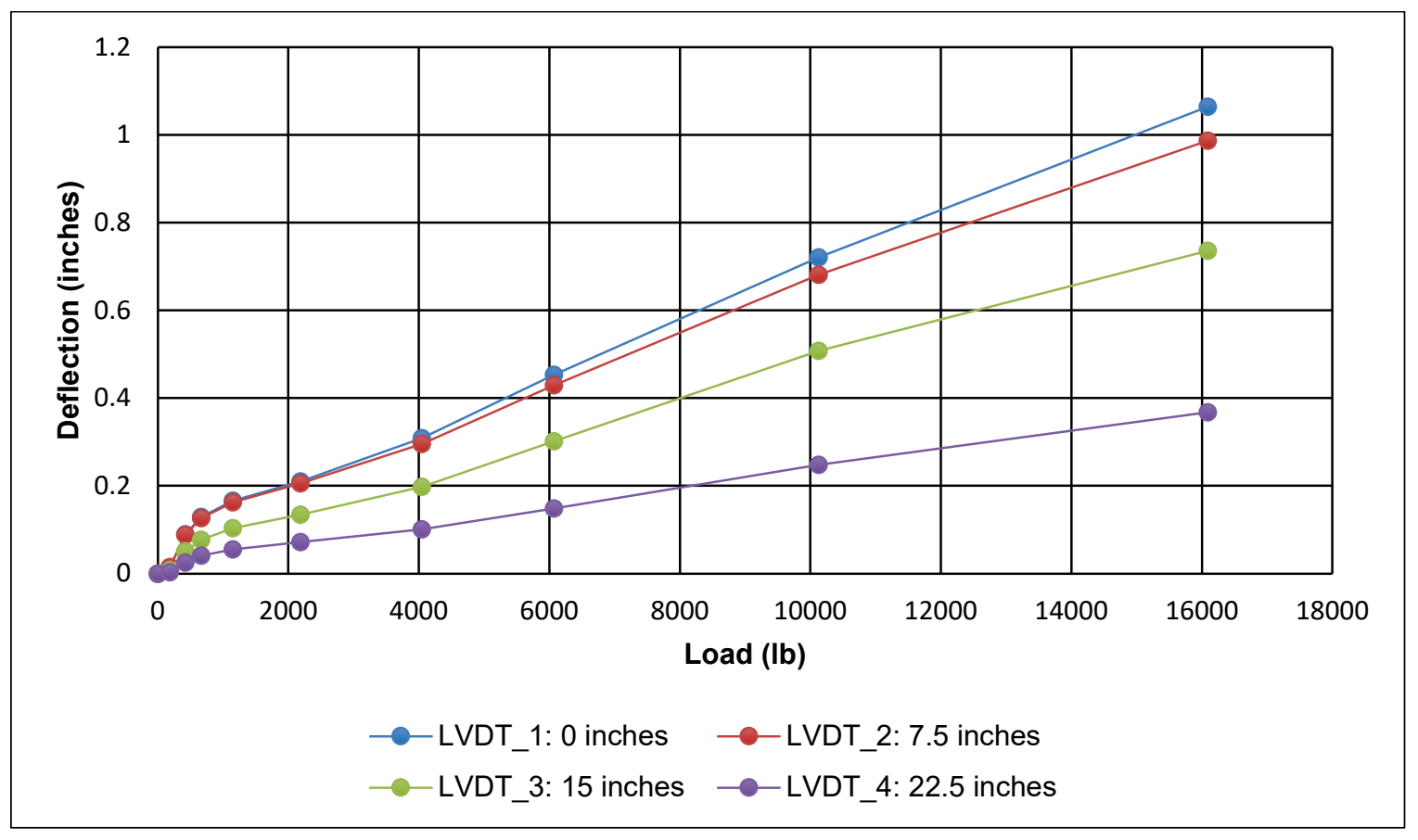

Figure B.13. PSA-FT-R multiple panel test, deflection vs. load (3 panels).

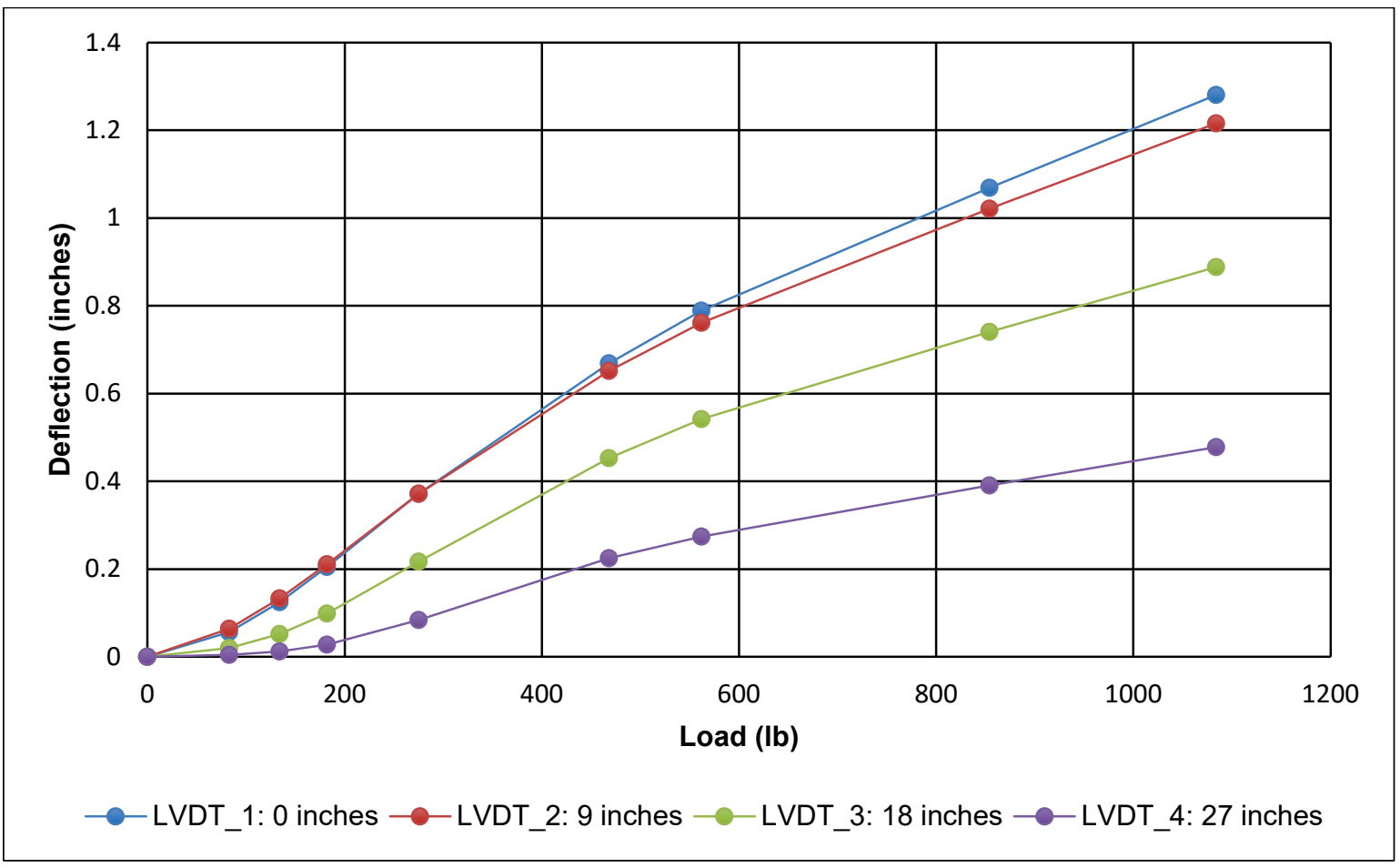


Figure B.14. PSA-FT-R multiple panel test, deflection vs. load (6 panels).

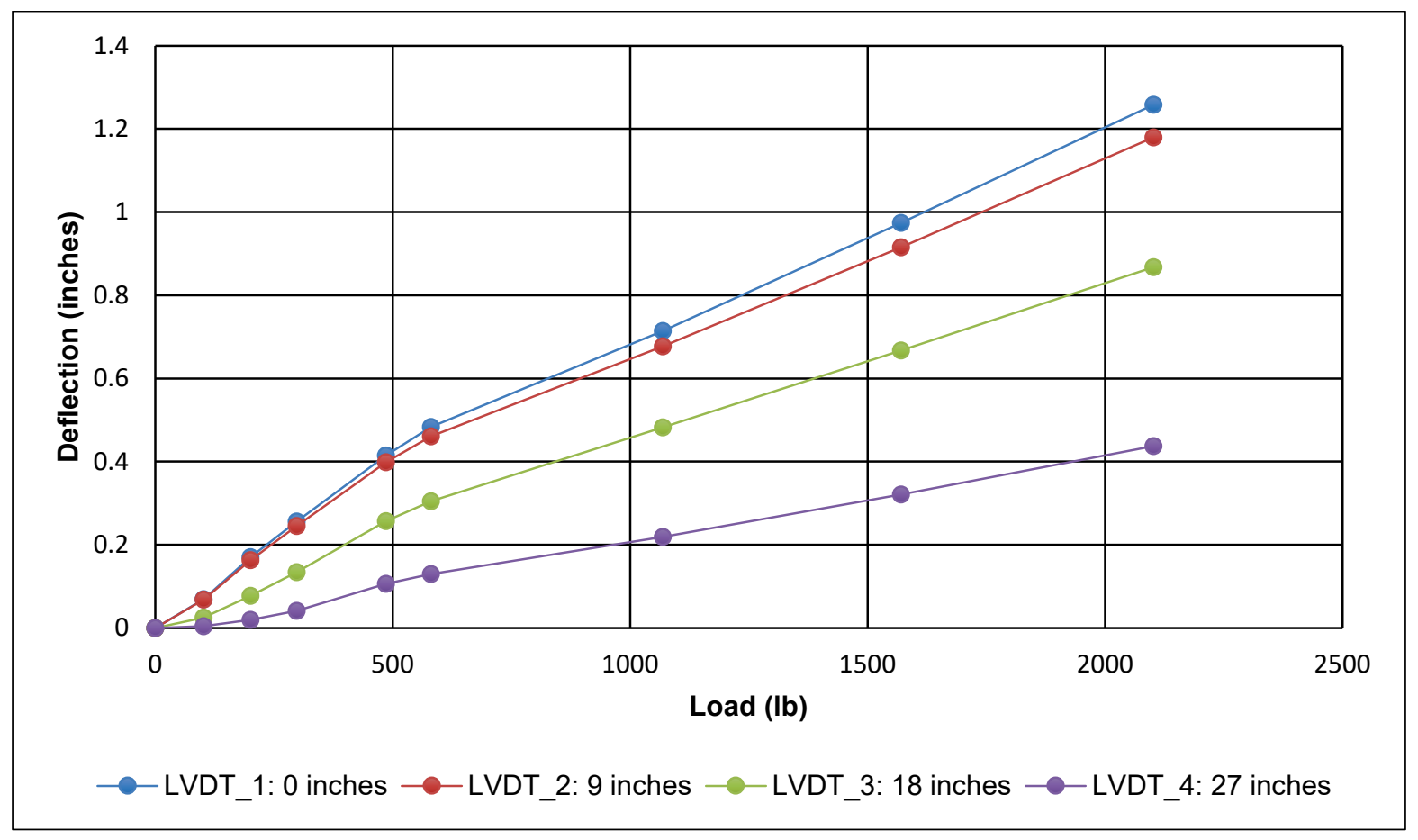




\section{Appendix C: Rectangular Plate Model Solution for Single Panel Configuration Tests}

This appendix reports the input and output data from the rectangular plate model for all of the matting systems tested in a single panel configuration.

Figure C.1. Input data for AM2 single panel test (120-in. span).

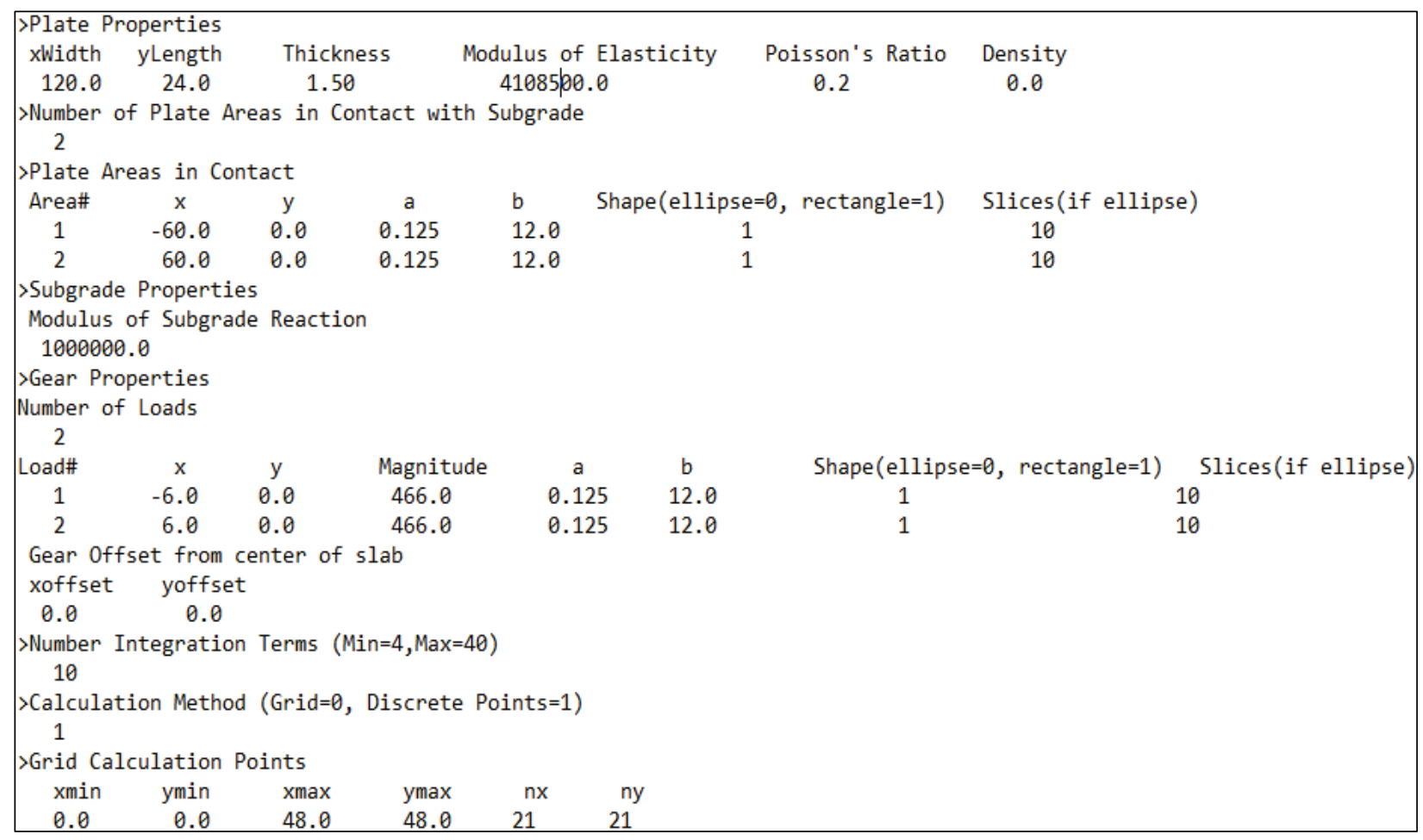


Figure C.2. Output data for AM2 single panel test (120-in. span).

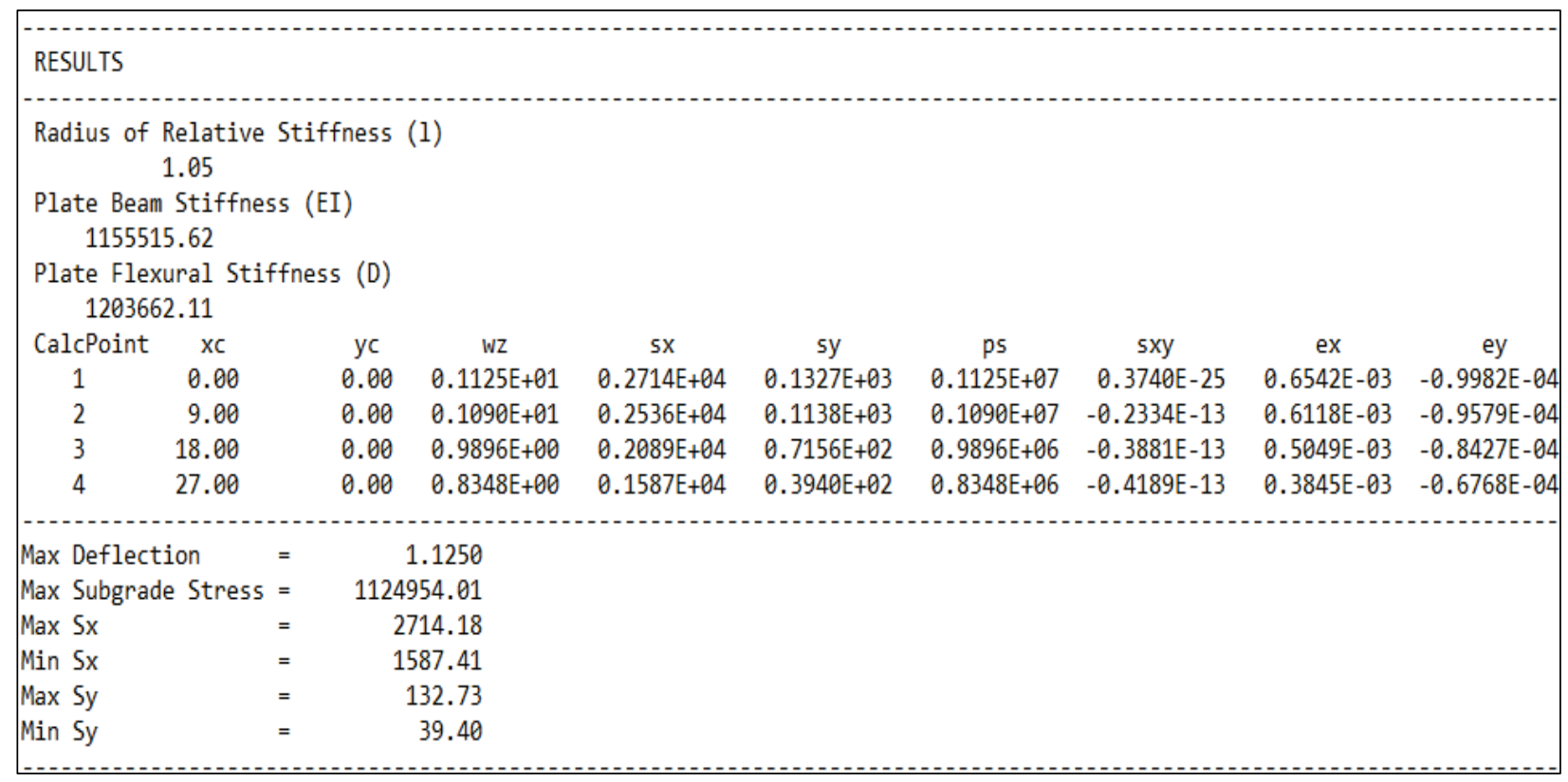

Figure C.3. Input data for PSA-FT-R single panel test.

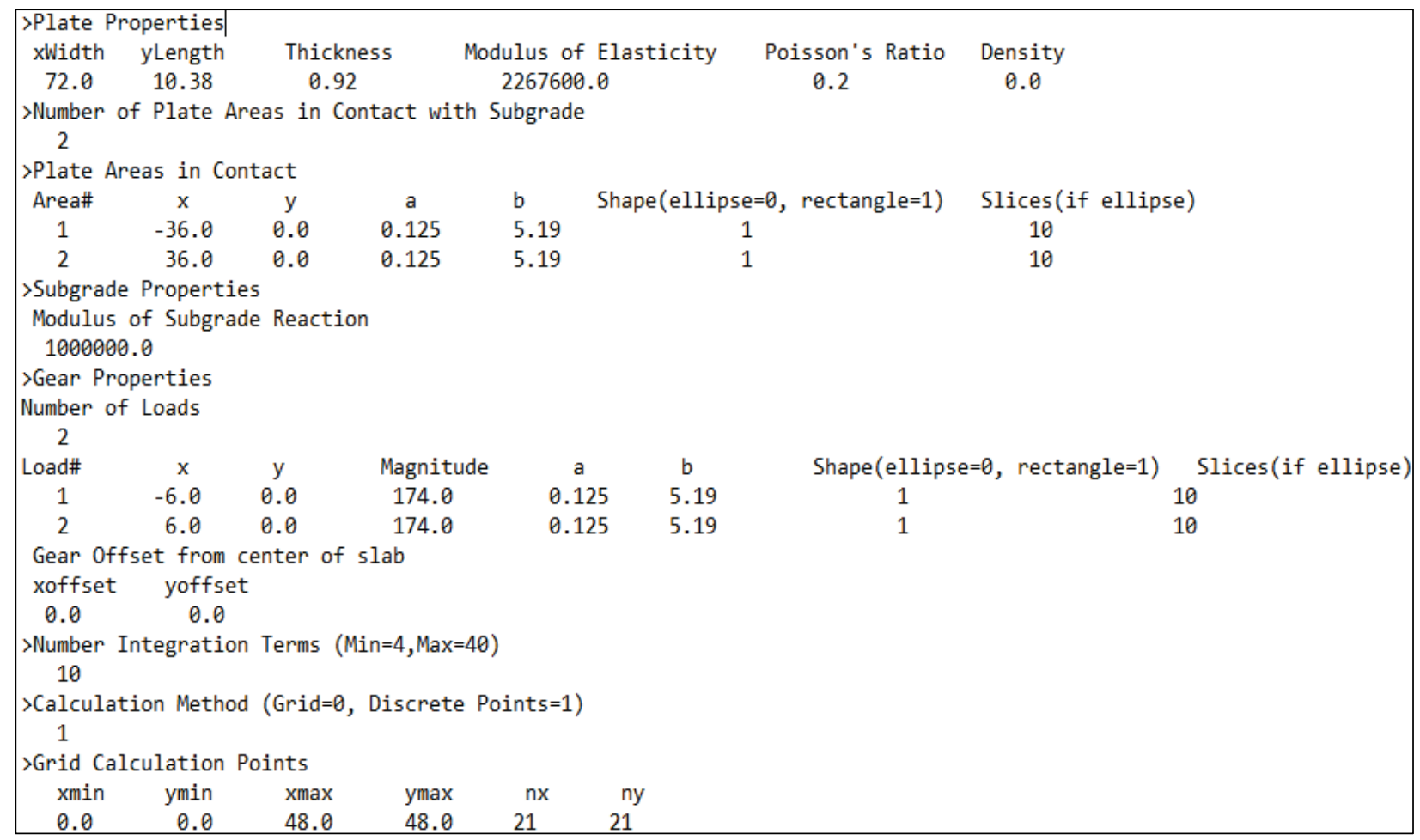


Figure C.4. Output data for PSA-FT-R single panel test.

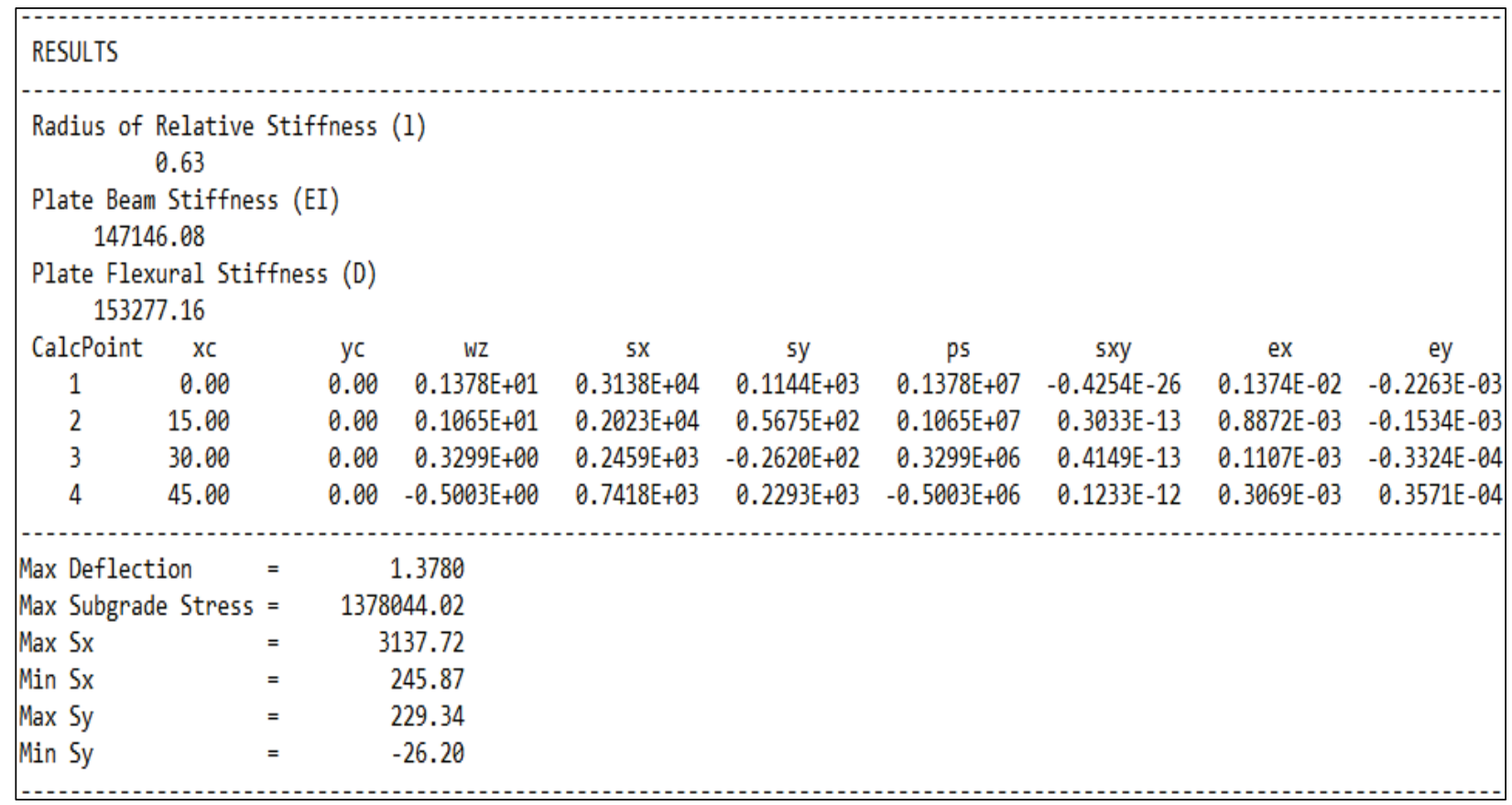

Figure C.5. Input data for ALMATS single panel test.

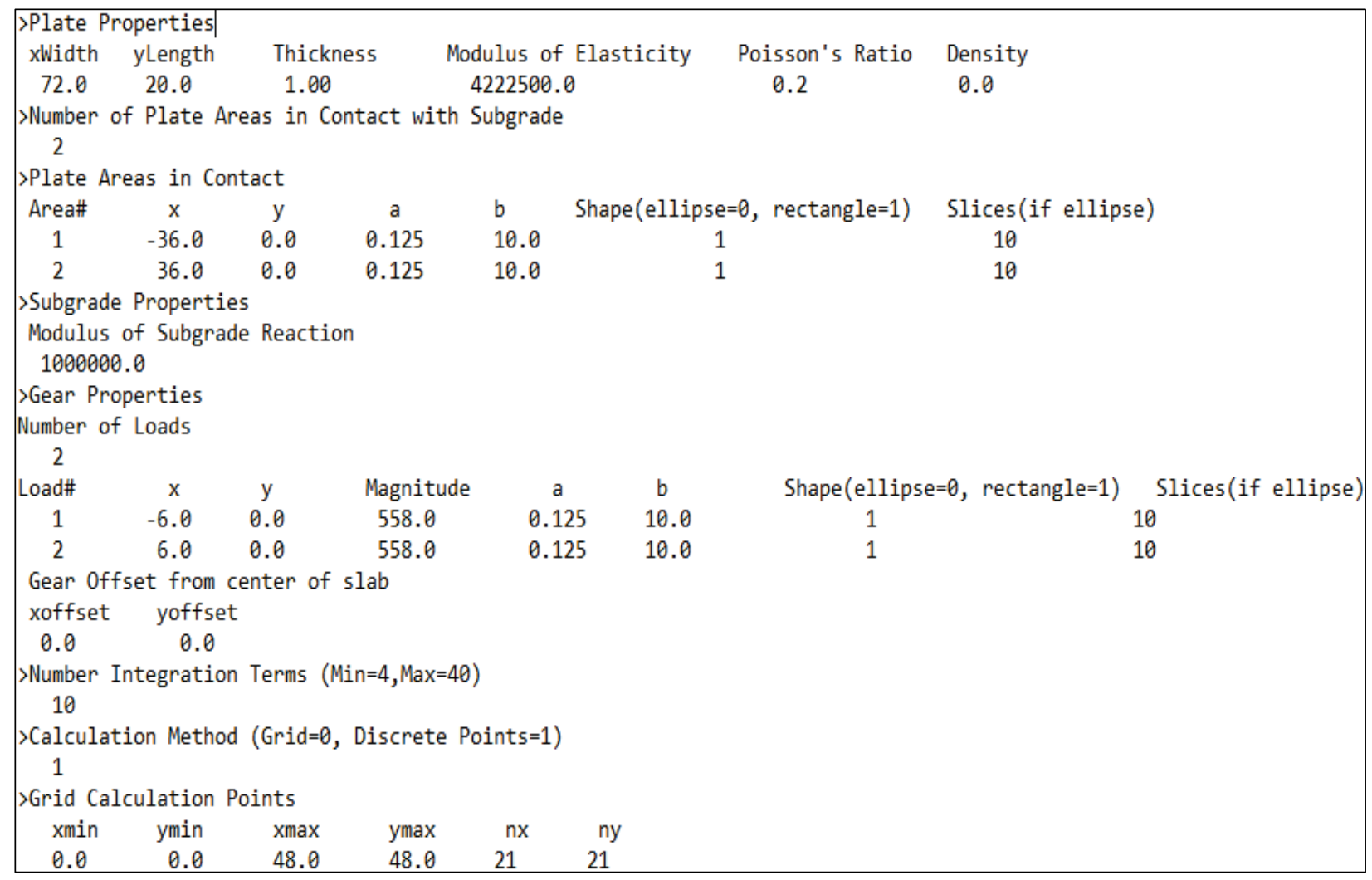


Figure C.6. Output data for ALMATS single panel test.

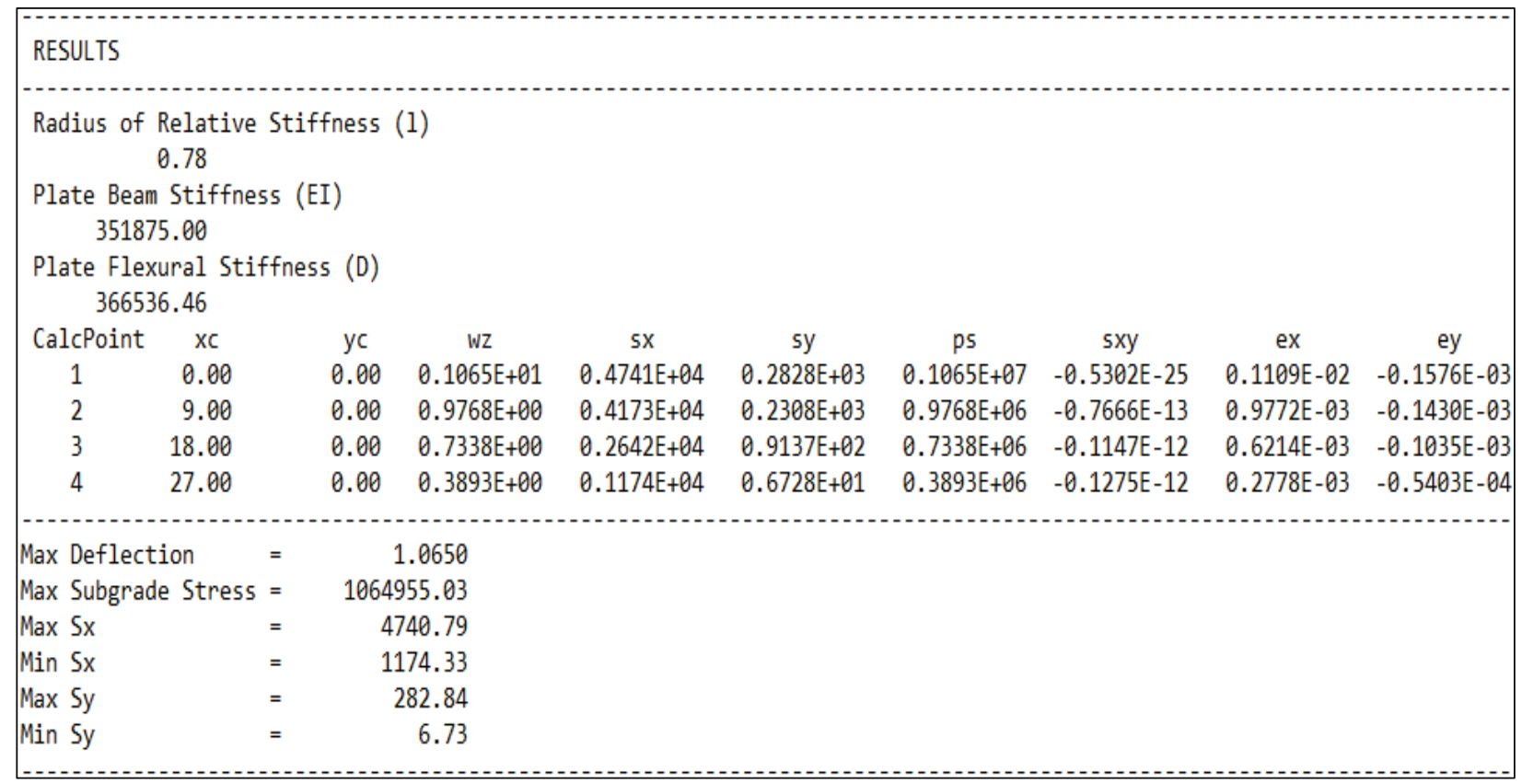

Figure C.7. Input data for Modified Light-Duty AM2 single panel test.

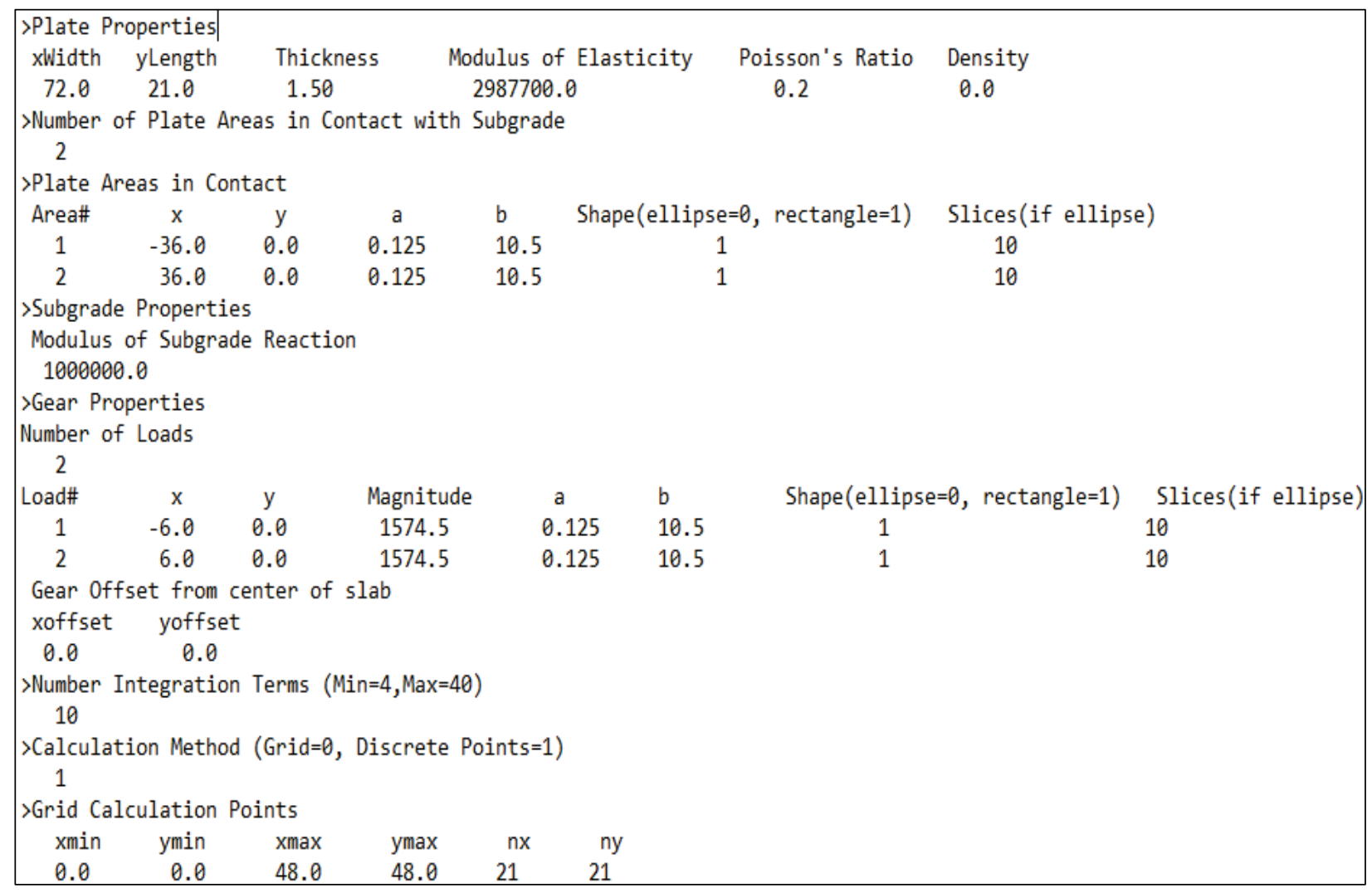


Figure C.8. Output data for Modified Light-Duty AM2 single panel test.

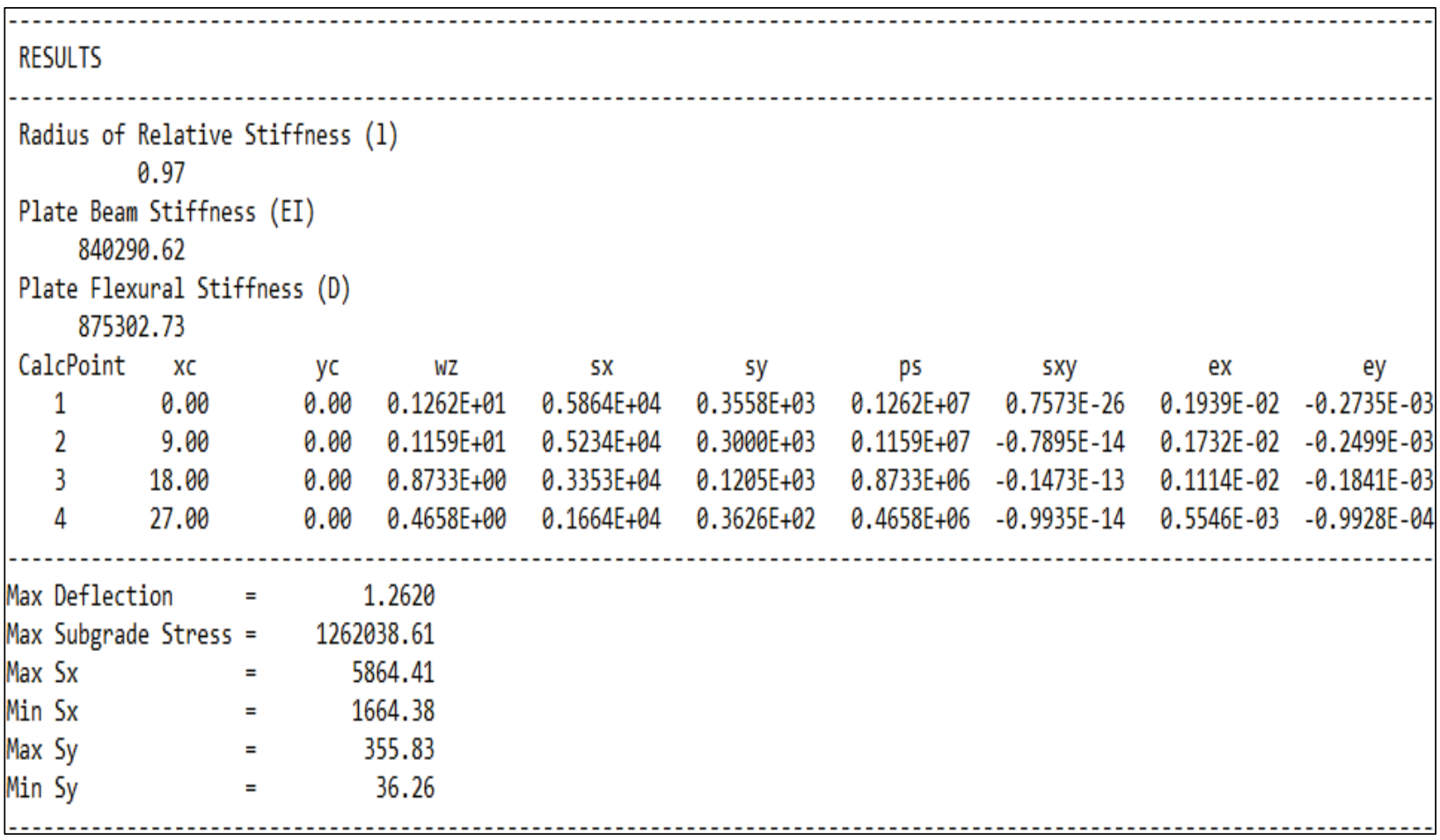

Figure C.9. Input data for \$46 single panel test.

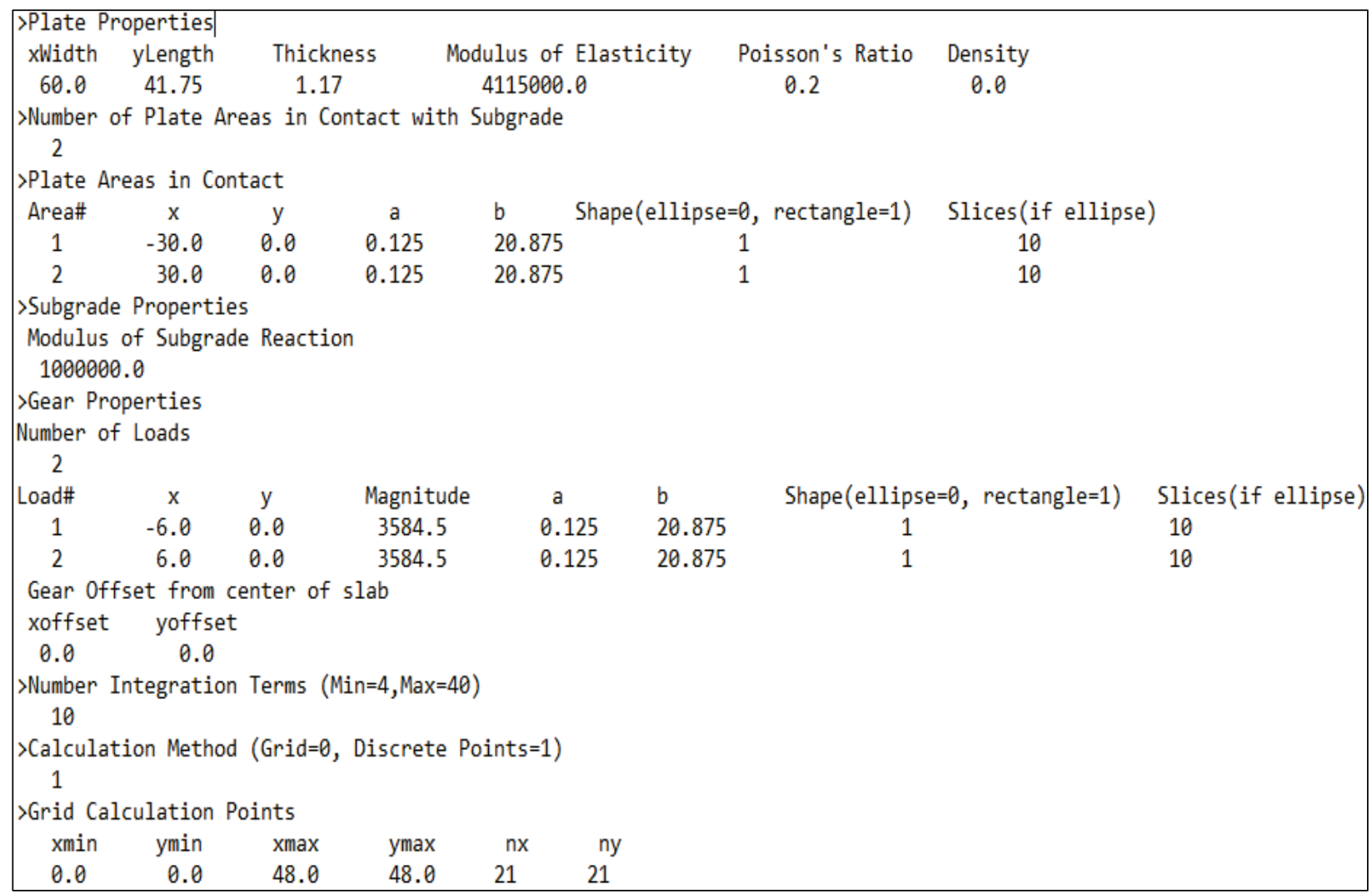


Figure C.10. Output data for $\$ 46$ single panel test.

\begin{tabular}{|c|c|c|c|c|c|c|c|c|c|c|}
\hline \multicolumn{11}{|l|}{ RESULTS } \\
\hline \multicolumn{11}{|c|}{$\begin{array}{c}\text { Radius of Relative Stiffness (1) } \\
0.87\end{array}$} \\
\hline \multicolumn{11}{|c|}{ Plate Beam Stiffness (EI) } \\
\hline \multicolumn{11}{|c|}{$\begin{array}{l}\text { Plate Flexural Stiffness (D) } \\
572103.95\end{array}$} \\
\hline CalcPoint & $x c$ & & yc & WZ & $5 x$ & sy & ps & sxy & ex & ey \\
\hline 1 & 0.00 & & 0.00 & $0.1214 \mathrm{E}+01$ & $0.8654 \mathrm{E}+04$ & $0.1180 \mathrm{E}+04$ & $0.1214 \mathrm{E}+07$ & $-0.1296 \mathrm{E}-24$ & $0.2046 \mathrm{E}-02$ & $-0.1339 \mathrm{E}-03$ \\
\hline 2 & 7.50 & & 0.00 & $0.1117 \mathrm{E}+01$ & $0.8002 E+04$ & $0.1084 \mathrm{E}+04$ & $0.1117 \mathrm{E}+07$ & $-0.2388 \mathrm{E}-12$ & $0.1892 \mathrm{E}-02$ & $-0.1255 E-03$ \\
\hline 3 & 15.00 & & 0.00 & $0.8423 \mathrm{E}+00$ & $0.5149 \mathrm{E}+04$ & $0.6260 \mathrm{E}+03$ & $0.8423 \mathrm{E}+06$ & $-0.4341 \mathrm{E}-12$ & $0.1221 \mathrm{E}-02$ & $-0.9812 E-04$ \\
\hline 4 & 22.50 & & 0.00 & $0.4492 \mathrm{E}+00$ & $0.2506 \mathrm{E}+04$ & $0.2741 E+03$ & $0.4492 \mathrm{E}+06$ & $-0.5407 \mathrm{E}-12$ & $0.5956 \mathrm{E}-03$ & $-0.5518 \mathrm{E}-04$ \\
\hline \multicolumn{11}{|c|}{ Max Deflection $\quad=\quad 1.2141$} \\
\hline \multicolumn{11}{|c|}{ Max Subgrade Stress $=\quad 1214120.17$} \\
\hline \multicolumn{3}{|c|}{$\operatorname{Max} 5 x$} & & 553.91 & & & & & & \\
\hline \multicolumn{2}{|l|}{ Min Sx } & $=$ & & 505.64 & & & & & & \\
\hline \multicolumn{2}{|l|}{ Max Sy } & $=$ & & 179.85 & & & & & & \\
\hline \multicolumn{2}{|l|}{ Min Sy } & $=$ & & 274.08 & & & & & & \\
\hline
\end{tabular}




\section{Appendix D: Rectangular Plate Model Solution for Multiple Panel Configuration Tests}

This appendix reports the input and output data from the rectangular plate model for all of the matting systems tested in a multiple panel configuration.

Figure D.1. Input data for AM2 multiple panel test (72-in. span).

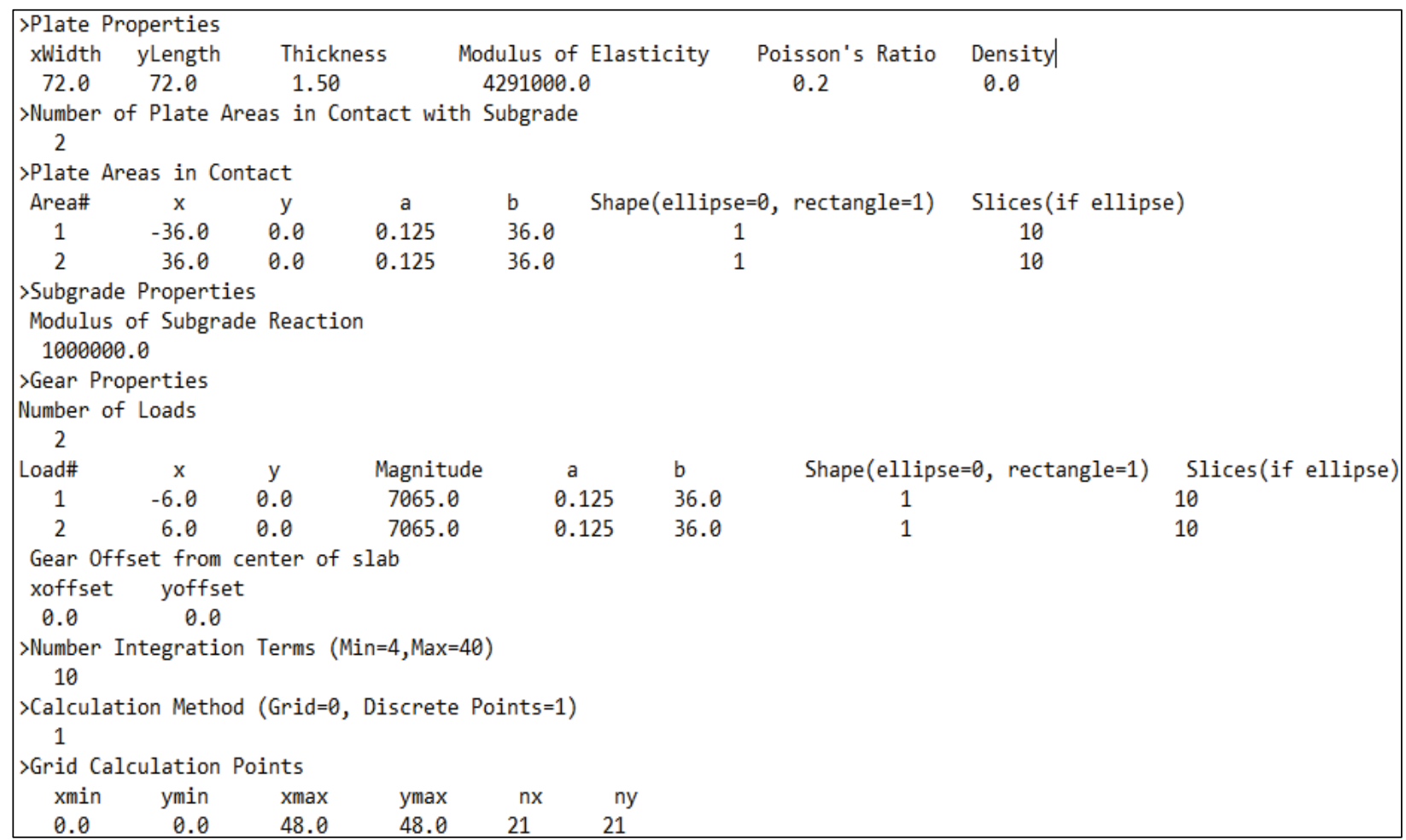


Figure D.2. Output data for AM2 multiple panel test (72-in. span).

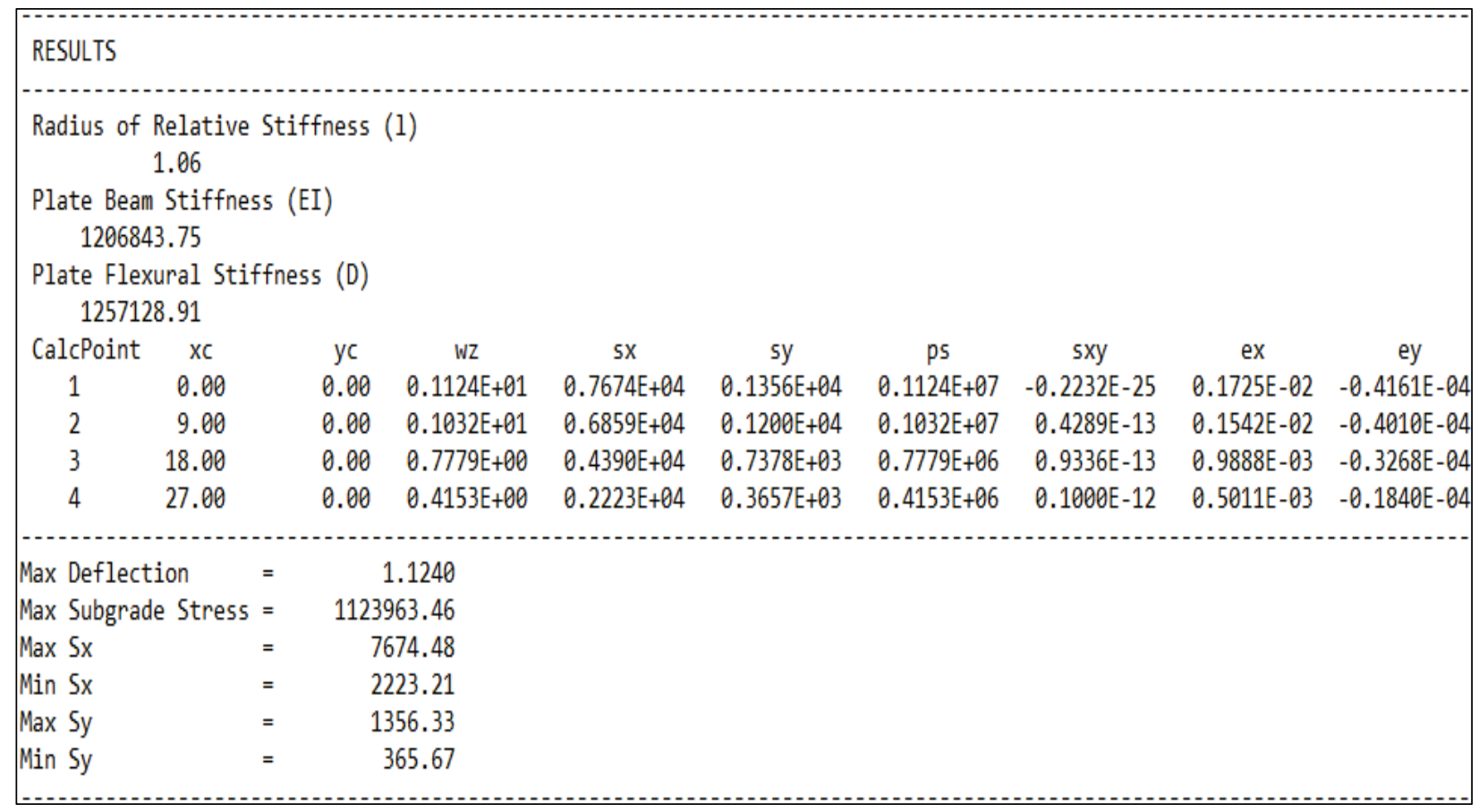

Figure D.3. Input data for AM2 multiple panel test (120-in. span).

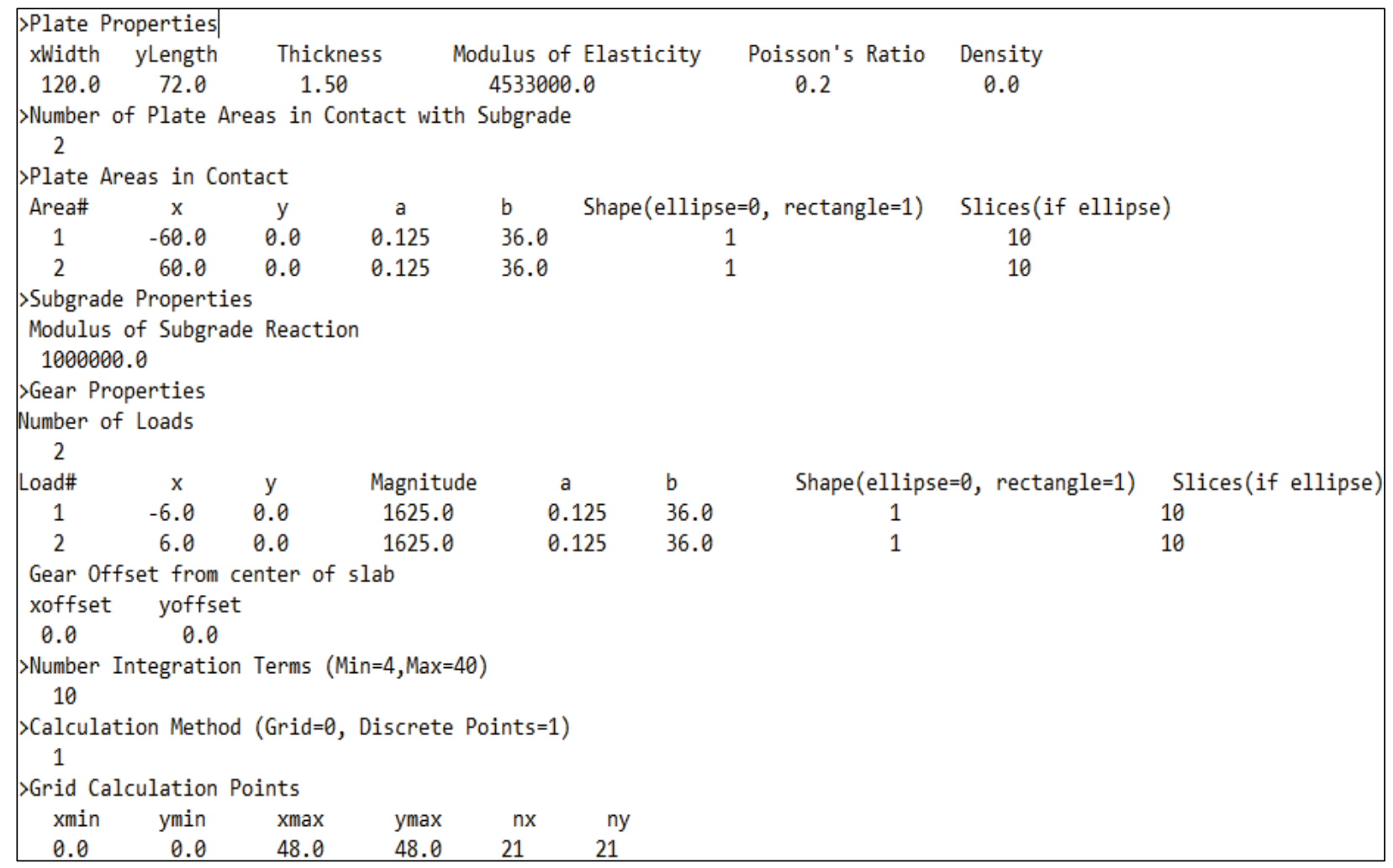


Figure D.4. Output data for AM2 multiple panel test (120-in. span).

\begin{tabular}{|c|c|c|c|c|c|c|c|c|c|c|}
\hline \multicolumn{11}{|l|}{ RESULTS } \\
\hline \multicolumn{11}{|c|}{$\begin{array}{c}\text { Radius of Relative Stiffness (1) } \\
1.07\end{array}$} \\
\hline & \multicolumn{3}{|c|}{ Plate Beam Stiffness (EI) } & & \multicolumn{6}{|c|}{1274906.25} \\
\hline \multicolumn{11}{|c|}{ Plate Flexural Stiffness (D) } \\
\hline CalcPoint & $\mathrm{xc}$ & & yc & Wz & sx & sy & ps & sxy & ex & ey \\
\hline 1 & 0.00 & & 0.00 & $0.1162 E+01$ & $0.3143 \mathrm{E}+04$ & $0.3995 \mathrm{E}+03$ & $0.1162 E+07$ & $0.1301 E-24$ & $0.6757 \mathrm{E}-03$ & $-0.5054 \mathrm{E}-04$ \\
\hline 2 & 15.00 & & 0.00 & $0.1064 \mathrm{E}+01$ & $0.2610 \mathrm{E}+04$ & $0.3049 \mathrm{E}+03$ & $0.1064 \mathrm{E}+07$ & $0.1087 \mathrm{E}-13$ & $0.5623 \mathrm{E}-03$ & $-0.4789 \mathrm{E}-04$ \\
\hline 3 & 30.00 & & 0.00 & $0.7989 \mathrm{E}+00$ & $0.1665 \mathrm{E}+04$ & $0.1638 \mathrm{E}+03$ & $0.7989 \mathrm{E}+06$ & $0.2355 E-13$ & $0.3600 \mathrm{E}-03$ & $-0.3732 E-04$ \\
\hline 4 & 45.00 & & 0.00 & $0.4252 \mathrm{E}+00$ & $0.8064 \mathrm{E}+03$ & $0.6746 \mathrm{E}+02$ & $0.4252 E+06$ & $0.1918 \mathrm{E}-13$ & $0.1749 \mathrm{E}-03$ & $-0.2070 \mathrm{E}-04$ \\
\hline Max Deflec & cion & $=$ & & 1.1620 & & & & & & \\
\hline Max Subgra & le Stress & $=$ & 1161 & 995.59 & & & & & & \\
\hline $\operatorname{Max} 5 \mathrm{x}$ & & $=$ & & 142.76 & & & & & & \\
\hline Min $5 x$ & & $=$ & & 806.39 & & & & & & \\
\hline Max Sy & & $=$ & & 399.47 & & & & & & \\
\hline Min Sy & & $=$ & & 67.46 & & & & & & \\
\hline
\end{tabular}

Figure D.5. Input data for PSA-FT-R multiple panel test (3 panels).

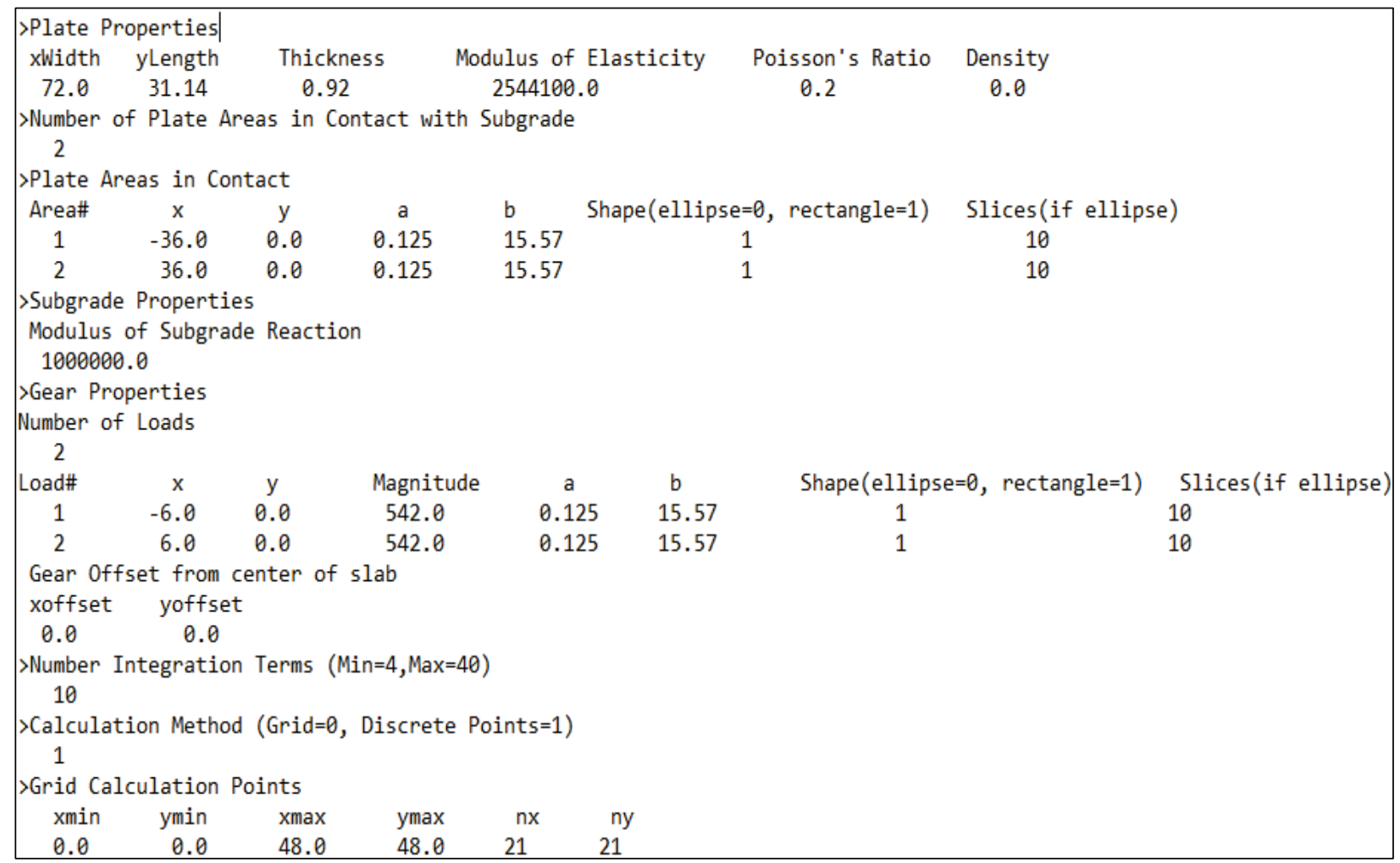


Figure D.6. Output data for PSA-FT-R multiple panel test (3 panels).

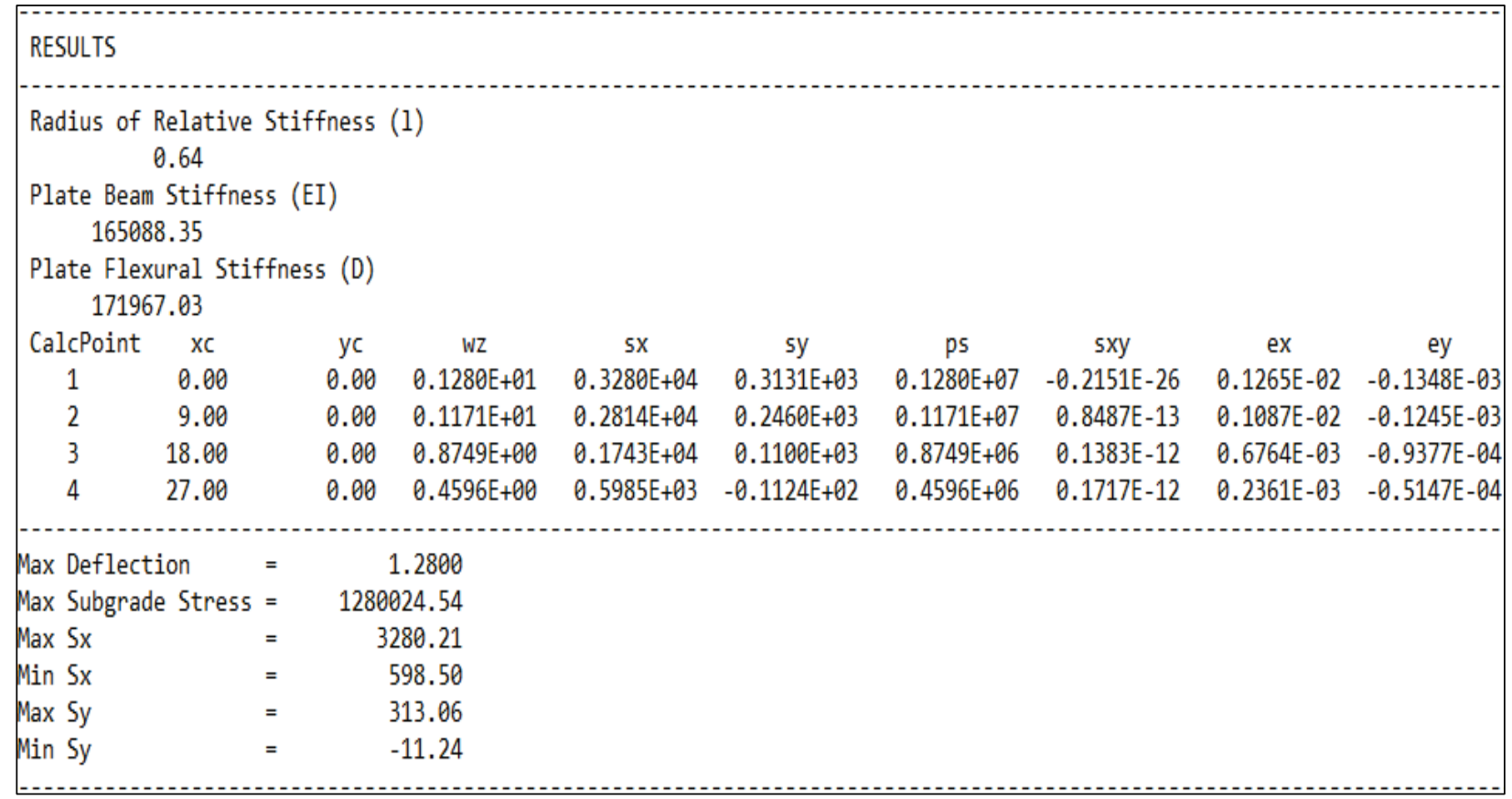

Figure D.7. Input data for PSA-FT-R multiple panel test (6 panels).

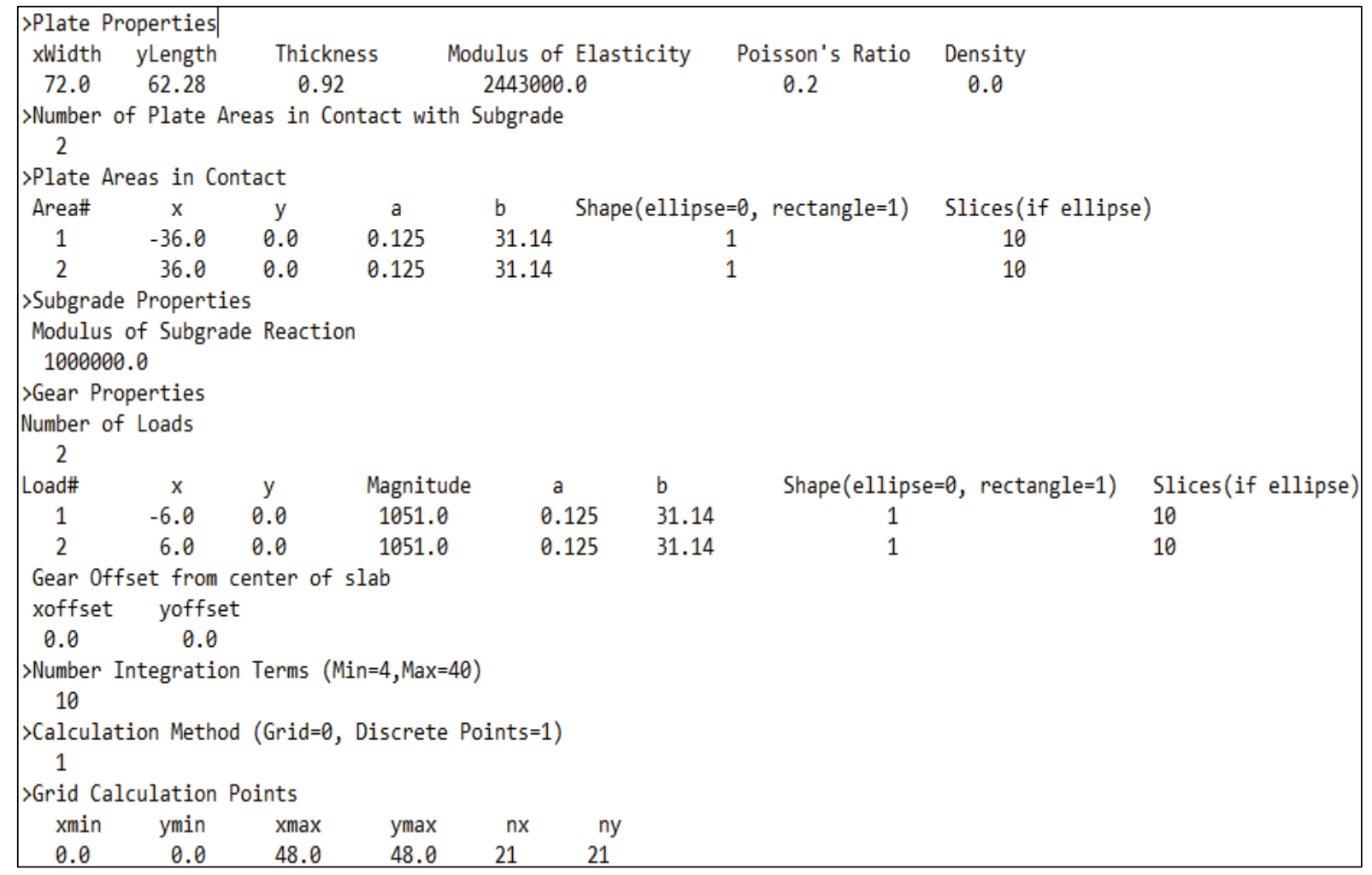


Figure D.8. Output data for PSA-FT-R multiple panel test (6 panels).

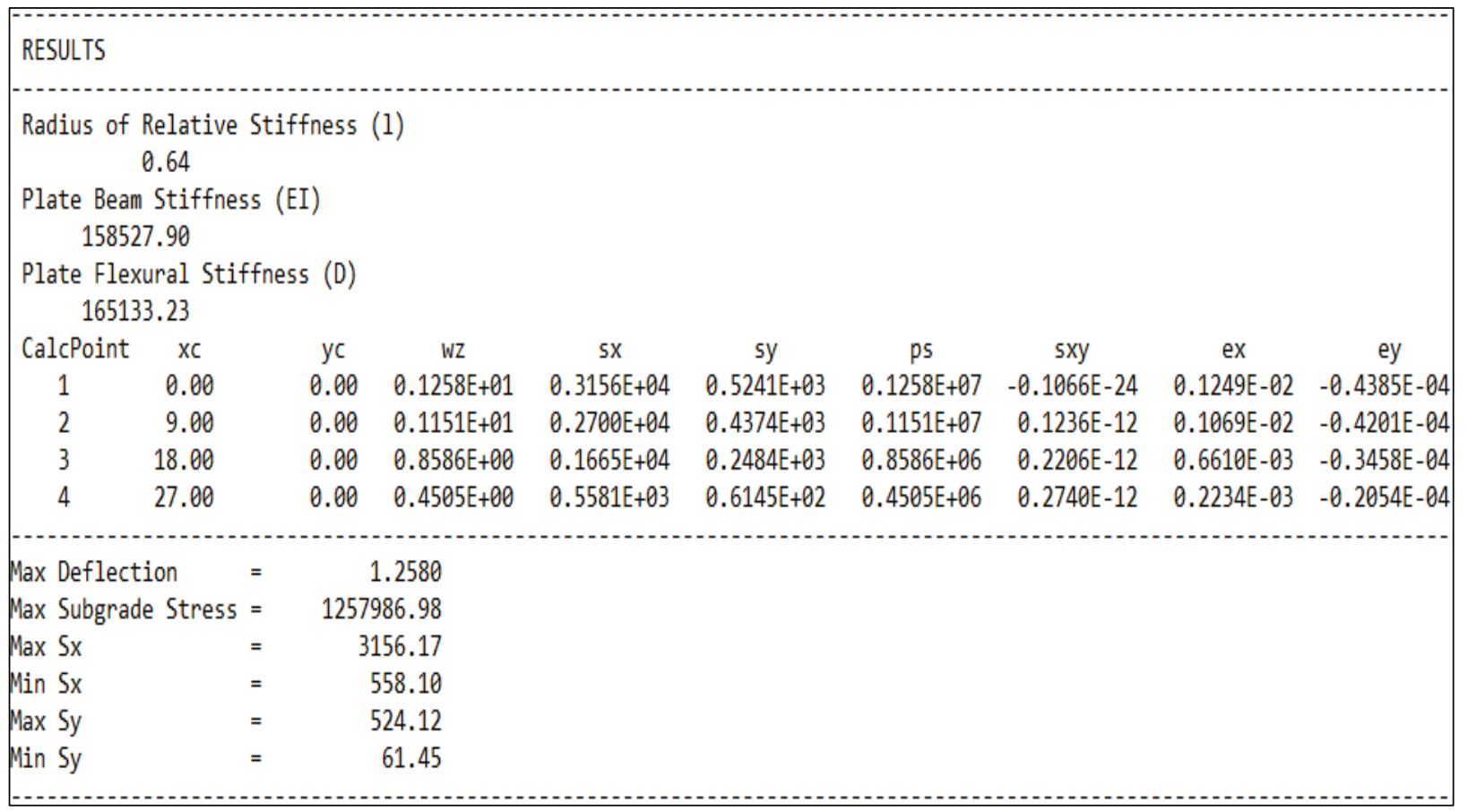

Figure D.9. Input data for ALMATS multiple panel test.

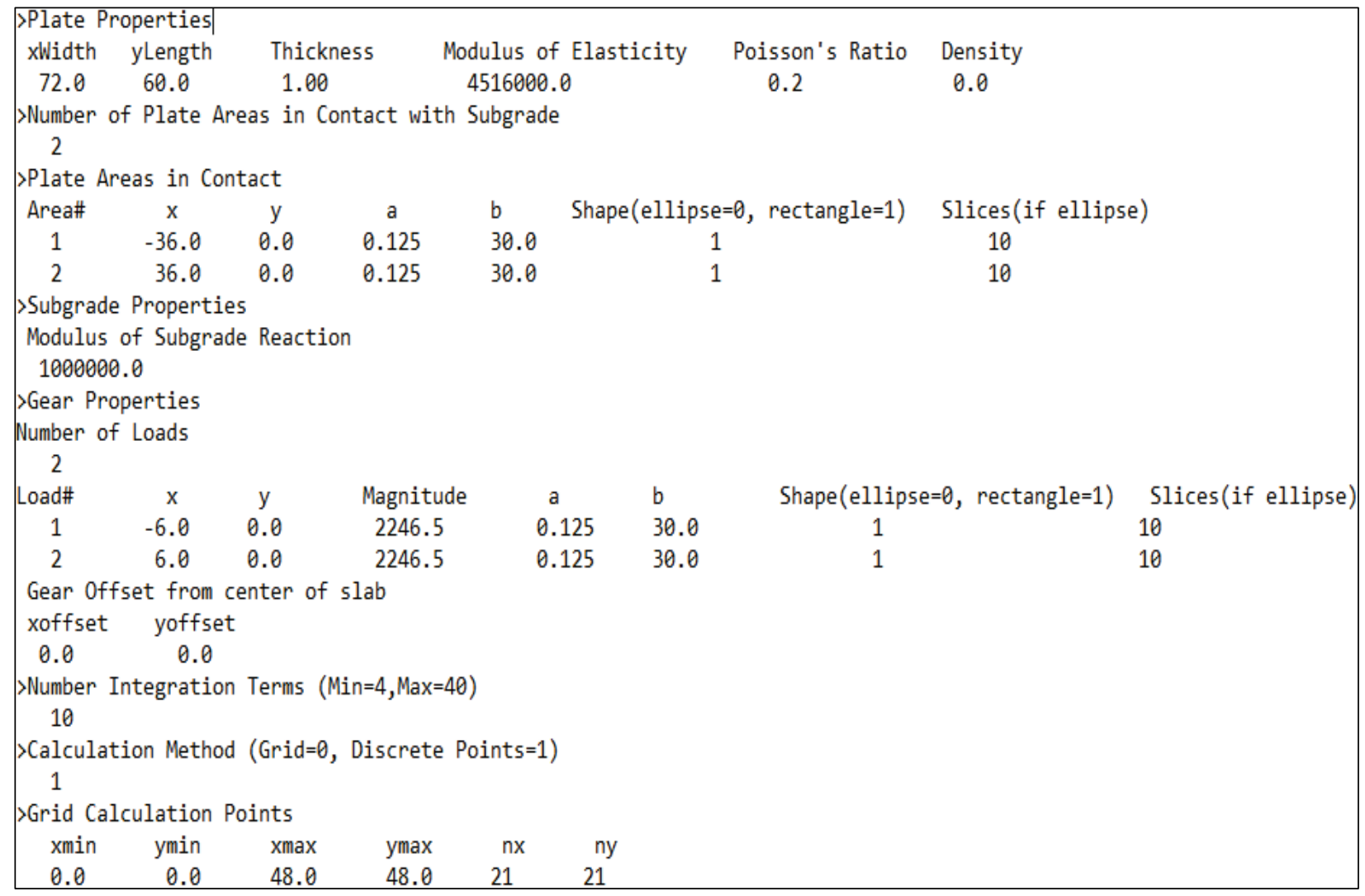


Figure D.10. Output data for ALMATS multiple panel test.

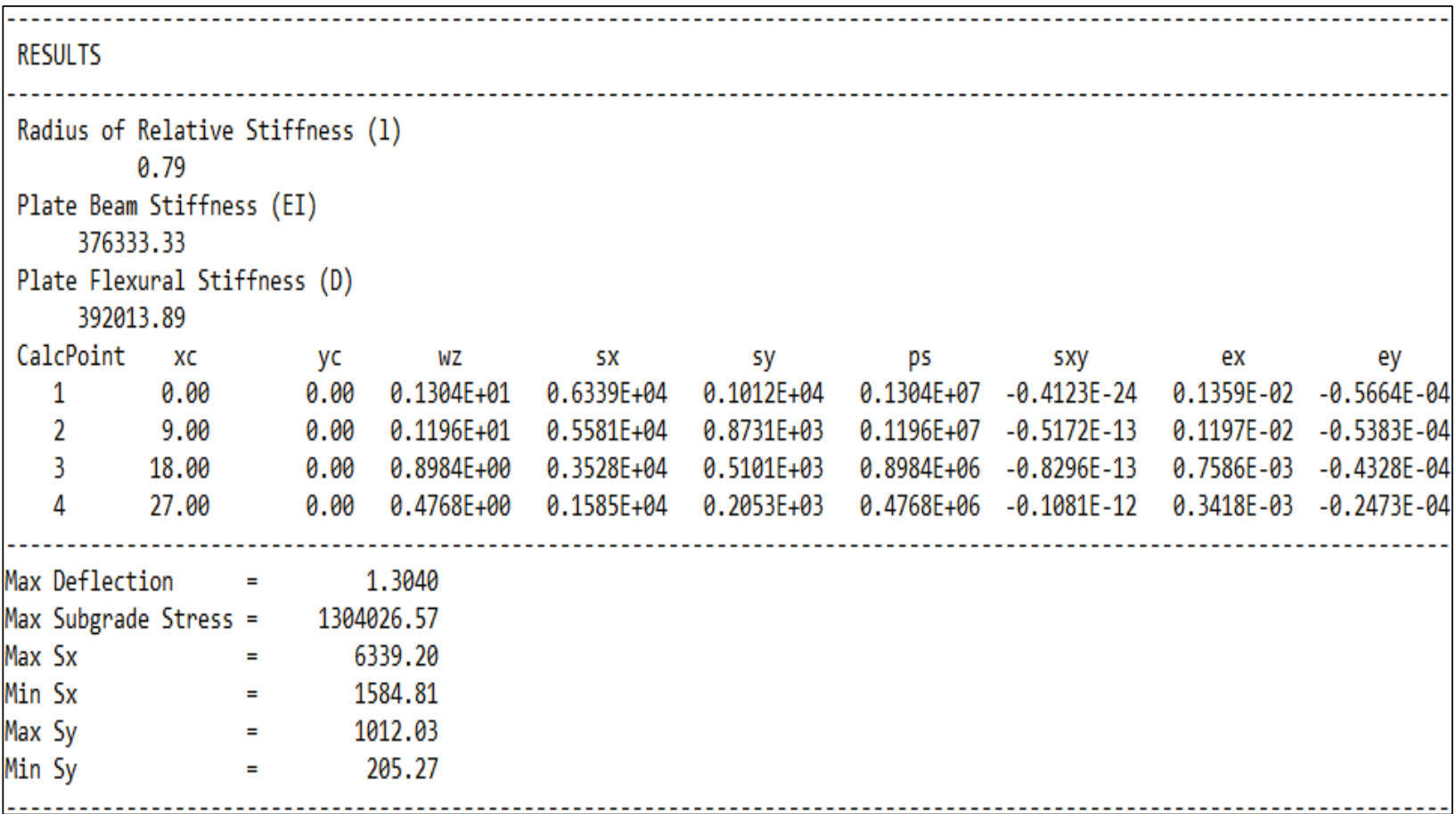

Figure D.11. Input data for Modified Light-Duty AM2 multiple panel test.

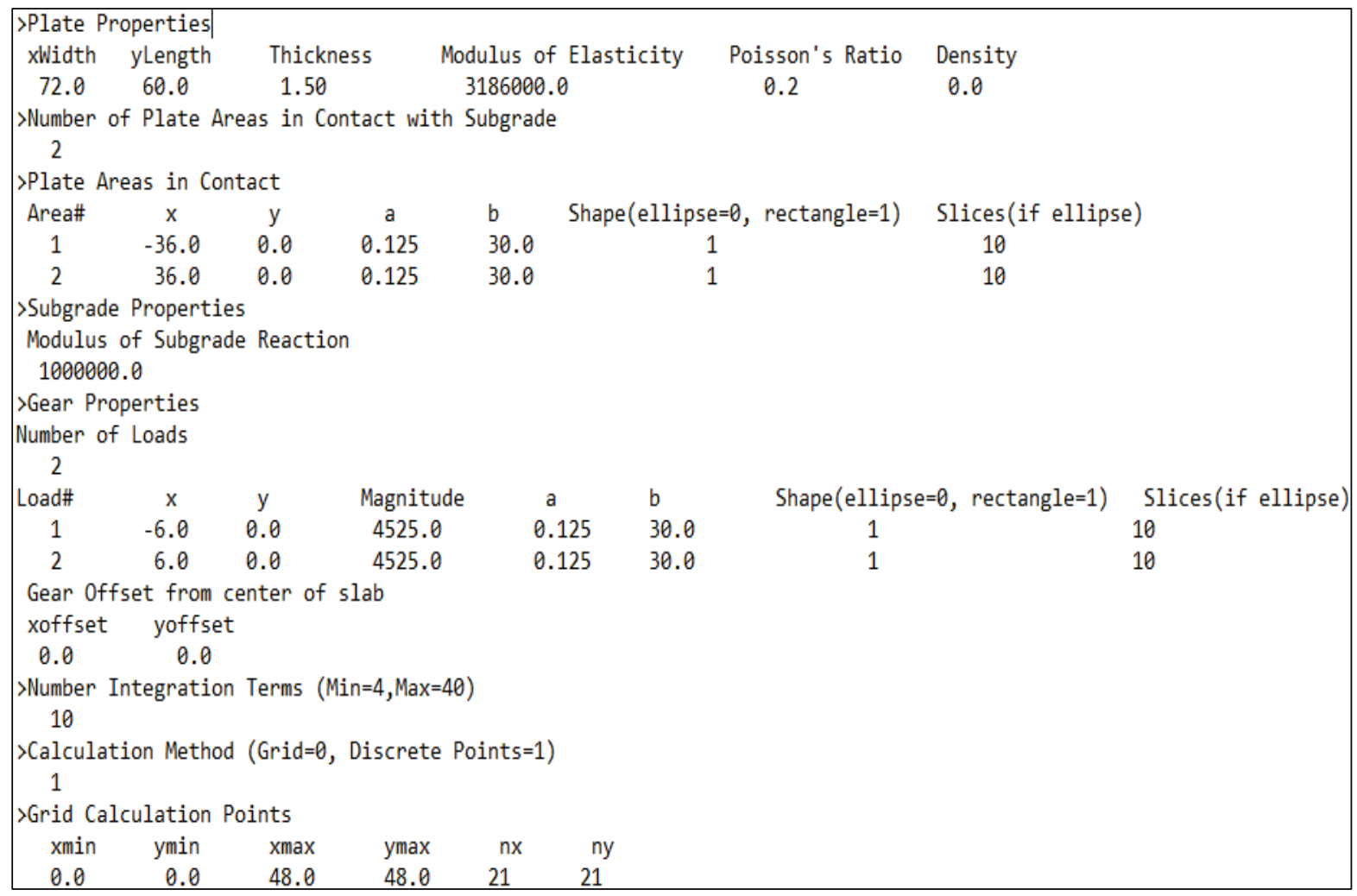


Figure D.12. Output data for Modified Light Duty AM2 multiple panel test.

\begin{tabular}{|c|c|c|c|c|c|c|c|c|c|c|}
\hline \multicolumn{11}{|l|}{ RESULTS } \\
\hline \multicolumn{11}{|c|}{$\begin{array}{c}\text { Radius of Relative Stiffness (1) } \\
0.98\end{array}$} \\
\hline \multicolumn{11}{|c|}{ Plate Beam Stiffness (EI) } \\
\hline \multicolumn{11}{|c|}{$\begin{array}{l}\text { Plate Flexural Stiffness (D) } \\
\quad 933398.44\end{array}$} \\
\hline CalcPoint & $\mathrm{xc}$ & & yc & WZ & sx & sy & ps & sxy & ex & ey \\
\hline 1 & 0.00 & & 0.00 & $0.1158 \mathrm{E}+01$ & $0.5863 \mathrm{E}+04$ & $0.9280 \mathrm{E}+03$ & $0.1158 \mathrm{E}+07$ & $-0.1641 E-24$ & $0.1782 \mathrm{E}-02$ & $-0.7676 \mathrm{E}-04$ \\
\hline 2 & 9.00 & & 0.00 & $0.1063 \mathrm{E}+01$ & $0.5228 \mathrm{E}+04$ & $0.8132 \mathrm{E}+03$ & $0.1063 \mathrm{E}+07$ & $-0.5130 \mathrm{E}-13$ & $0.1590 \mathrm{E}-02$ & $-0.7295 E-04$ \\
\hline 3 & 18.00 & & 0.00 & $0.8010 \mathrm{E}+00$ & $0.3341 E+04$ & $0.4833 \mathrm{E}+03$ & $0.8010 \mathrm{E}+06$ & $-0.8287 \mathrm{E}-13$ & $0.1018 \mathrm{E}-02$ & $-0.5805 E-04$ \\
\hline 4 & 27.00 & & 0.00 & $0.4272 E+00$ & $0.1662 E+04$ & $0.2284 \mathrm{E}+03$ & $0.4272 E+06$ & $-0.1238 \mathrm{E}-12$ & $0.5074 \mathrm{E}-03$ & $-0.3267 E-04$ \\
\hline \multicolumn{11}{|c|}{ Max Deflection $\quad=\quad 1.1580$} \\
\hline \multicolumn{11}{|c|}{ Max Subgrade Stress $=1158028.06$} \\
\hline \multicolumn{10}{|c|}{$\mid \begin{array}{rrr}\text { Max Subgrade Stress } & = & 1158028.06 \\
\operatorname{Max} \text { Sx } & = & 5863.00\end{array}$} & \\
\hline \multicolumn{2}{|l|}{ Min Sx } & $=$ & & 662.16 & & & & & & \\
\hline \multicolumn{2}{|l|}{ Max Sy } & $=$ & & 928.03 & & & & & & \\
\hline \multicolumn{2}{|l|}{ Min Sy } & $=$ & & 228.36 & & & & & & \\
\hline
\end{tabular}

Figure D.13. Input data for \$46 multiple panel test.

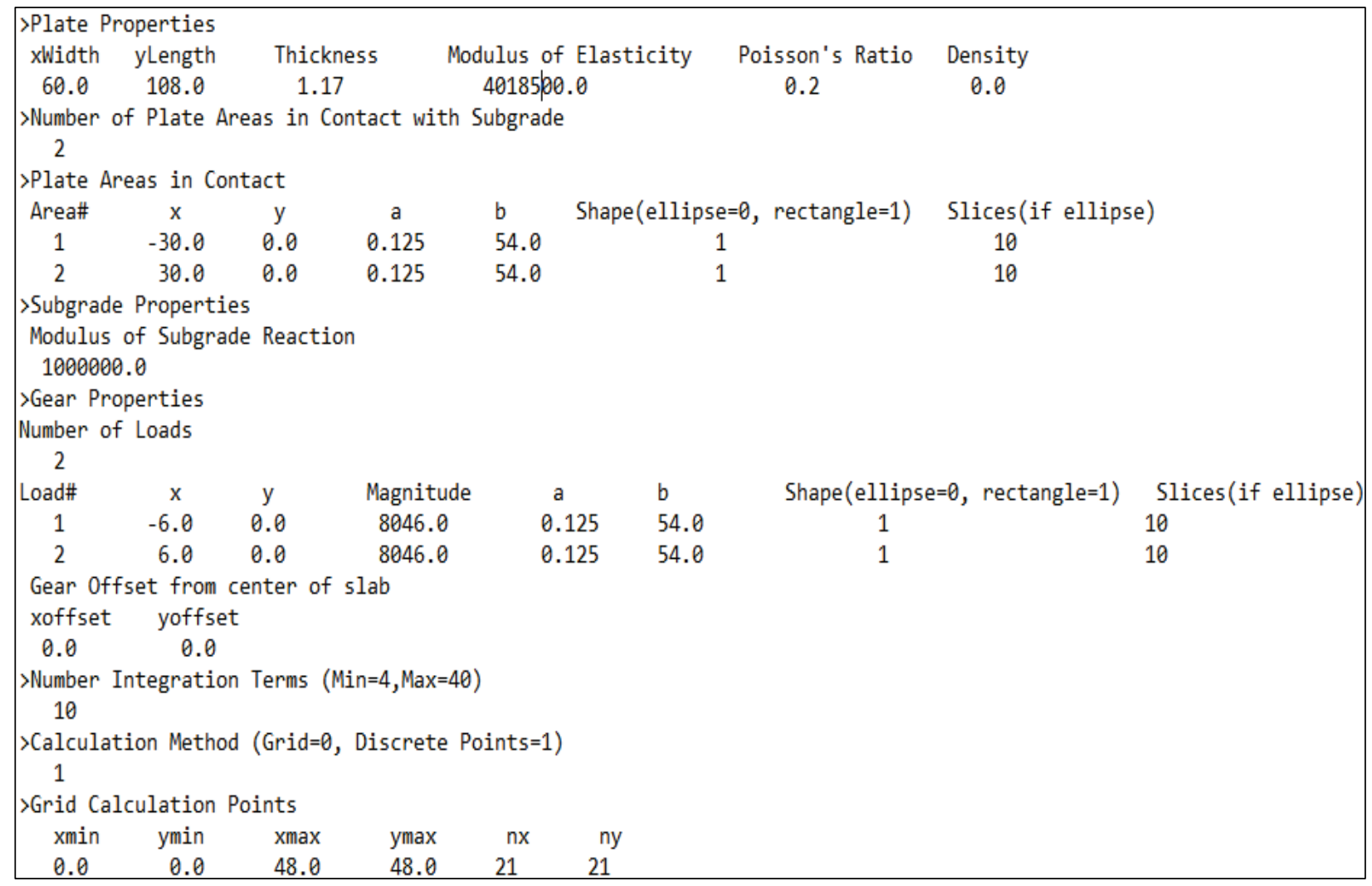


Figure D.14. Output data for $\$ 46$ multiple panel test.

\begin{tabular}{|c|c|c|c|c|c|c|c|c|c|c|}
\hline \multicolumn{11}{|l|}{ RESULTS } \\
\hline \multicolumn{11}{|c|}{$\begin{array}{c}\text { Radius of Relative Stiffness (1) } \\
0.86\end{array}$} \\
\hline \multicolumn{11}{|c|}{ Plate Beam Stiffness (EI) } \\
\hline \multicolumn{11}{|c|}{536340.15} \\
\hline \multicolumn{11}{|c|}{$\begin{array}{l}\text { Plate Flexural Stiffness (D) } \\
\quad 558687.66\end{array}$} \\
\hline CalcPoint & $\mathrm{xc}$ & & yc & WZ & $5 x$ & sy & ps & sxy & ex & ey \\
\hline 1 & 0.00 & & 0.00 & $0.1064 \mathrm{E}+01$ & $0.7537 \mathrm{E}+04$ & $0.1608 \mathrm{E}+04$ & $0.1064 \mathrm{E}+07$ & $-0.1372 E-25$ & $0.1796 \mathrm{E}-02$ & $0.2493 \mathrm{E}-04$ \\
\hline 2 & 9.00 & & 0.00 & $0.9414 \mathrm{E}+00$ & $0.6582 \mathrm{E}+04$ & $0.1402 E+04$ & $0.9414 \mathrm{E}+06$ & $0.1920 \mathrm{E}-12$ & $0.1568 \mathrm{E}-02$ & $0.2138 \mathrm{E}-04$ \\
\hline 3 & 18.00 & & 0.00 & $0.6094 \mathrm{E}+00$ & $0.3538 \mathrm{E}+04$ & $0.7587 \mathrm{E}+03$ & $0.6094 \mathrm{E}+06$ & $0.3507 \mathrm{E}-12$ & $0.8426 \mathrm{E}-03$ & $0.1273 \mathrm{E}-04$ \\
\hline 4 & 27.00 & & 0.00 & $0.1597 \mathrm{E}+00$ & $0.5578 \mathrm{E}+03$ & $0.1271 \mathrm{E}+03$ & $0.1597 \mathrm{E}+06$ & $0.4134 \mathrm{E}-12$ & $0.1325 \mathrm{E}-03$ & $0.3863 \mathrm{E}-05$ \\
\hline \multicolumn{11}{|c|}{ Max Deflection $=1.0640$} \\
\hline \multicolumn{11}{|c|}{ Max Subgrade Stress $=\quad 1064046.77$} \\
\hline \multicolumn{11}{|c|}{$\operatorname{Max} S x=7536.75$} \\
\hline \multicolumn{2}{|l|}{ Min Sx } & $=$ & & 557.78 & & & & & & \\
\hline \multicolumn{2}{|l|}{ Max Sy } & $=$ & & 607.55 & & & & & & \\
\hline \multicolumn{2}{|l|}{ Min Sy } & $=$ & & 127.08 & & & & & & \\
\hline
\end{tabular}




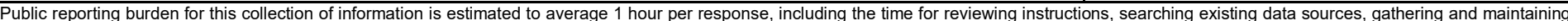

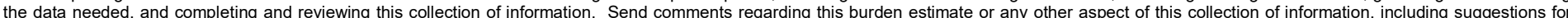

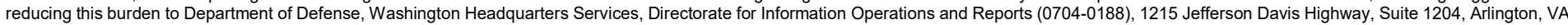

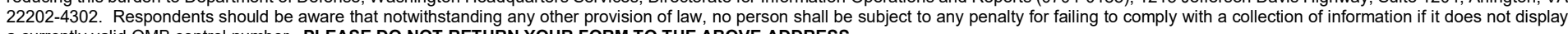
a currently valid OMB control number. PLEASE DO NOT RETURN YOUR FORM TO THE ABOVE ADDRESS.
1. REPORT DATE (DD-MM-YYYY) 2. REPORT TYPE
3. DATES COVERED (From - To)

March 2019 Final

\section{TITLE AND SUBTITLE}

Determination of Structural Properties of Airfield Matting

5a. CONTRACT NUMBER

5b. GRANT NUMBER

5c. PROGRAM ELEMENT NUMBER

\section{AUTHOR(S)}

Lyan Garcia and Nolan R. Hoffman

\section{5d. PROJECT NUMBER}

471376

5e. TASK NUMBER

5f. WORK UNIT NUMBER

\section{PERFORMING ORGANIZATION NAME(S) AND ADDRESS(ES)}

Geotechnical and Structures Laboratory

U.S. Army Engineer Research and Development Center

3909 Halls Ferry Road

Vicksburg, MS 39180-6199

\section{SPONSORING / MONITORING AGENCY NAME(S) AND ADDRESS(ES)}

Headquarters, Air Force Civil Engineer Center

Tyndall Air Force Base, FL 32403-5319
8. PERFORMING ORGANIZATION REPORT NUMBER

ERDC/GSL TR-19-8
10. SPONSOR/MONITOR'S ACRONYM(S)

AFCEC

11. SPONSOR/MONITOR'S REPORT NUMBER(S)

\section{DISTRIBUTION / AVAILABILITY STATEMENT}

Approved for public release; distribution is unlimited.

\section{SUPPLEMENTARY NOTES}

\section{ABSTRACT}

The evaluation of the interaction between airfield matting and soil under aircraft loading has been part of ongoing investigations under the AMX and Remote Piloted Aircraft (RPA) lightweight mat programs. Full-scale evaluations on controlled subgrades using simulated aircraft loads have successfully provided a realistic performance measure of airfield mats in an operational environment. To better understand airfield mat behavior, a medium-scale bending experiment was performed to determine structural properties that can be related to field performance. This report presents data from experiments performed on new, lightweight matting systems investigated under the AMX and RPA lightweight mat programs using the medium-scale simply supported bending test. Full-scale traffic testing has previously been completed, but the structural and mechanical properties of the lightweight airfield mat designs have not been determined. A finite element implementation of the Mindlin plate theory was used to back-calculate mat modulus and flexural stiffness.

Results showed reasonable relationships with field performance.

\begin{tabular}{|ll}
\hline 15. SUBJECT TERMS & Airfield matting \\
& Structural matting system \\
& Lightweight mat program
\end{tabular}

16. SECURITY CLASSIFICATION OF:

\begin{tabular}{|l|l|}
\hline a. REPORT & b. ABSTRACT \\
Unclassified & Unclassified
\end{tabular}

17. LIMITATION OF ABSTRACT
18. NUMBER OF PAGES

59 19a. NAME OF RESPONSIBLE PERSON

19b. TELEPHONE NUMBER (include area code) 